\title{
EFEITO DE Saccharomyces cerevisiae NA SÍNTESE DE FITOALEXINAS EM SORGO, NA GERMINAÇÃO E FORMAÇÃO DE APRESSÓRIOS POR FUNGOS FITOPATOGÊNICOS E NA PROTEÇÃO DE PEPINO A Colletotrichum lagenarium E SORGO A Colletotrichum sublineolum
}

\author{
SOLANGE MARIA BONALDO
}

Tese apresentada à Escola Superior de Agricultura "Luiz de Queiroz", Universidade de São Paulo, para obtenção do título de Doutor em Agronomia, Área de concentração: Fitopatologia.

\author{
PIR A C I C A B A \\ Estado de São Paulo - Brasil \\ Fevereiro - 2005
}




\title{
EFEITO DE Saccharomyces cerevisiae NA SÍNTESE DE FITOALEXINAS EM SORGO, NA GERMINAÇÃO E FORMAÇÃO DE APRESSÓRIOS POR FUNGOS FITOPATOGÊNICOS E NA PROTEÇÃO DE PEPINO A Colletotrichum lagenarium E SORGO A Colletotrichum sublineolum
}

\section{SOLANGE MARIA BONALDO}

Engenheiro Agrônomo

Orientador: Prof. Dr. SÉRGIO FLORENTINO PASCHOLATI

\author{
Tese apresentada à Escola Superior de \\ Agricultura "Luiz de Queiroz", Universidade de \\ São Paulo, para obtenção do título de Doutor em \\ Agronomia, Área de concentração: Fitopatologia.
}

\author{
PIR A C I C A B A \\ Estado de São Paulo - Brasil \\ Fevereiro - 2005
}


Dados I nt er naci onai s de Cat al ogação na Publ i cação ( Cl P) DI VI SÃO DE BI BLI OTECA E DOCUMENTAÇÃO - ESALQI USP

Bonaldo, Solange Maria

Efeito de Saccharomyces cerevisiae na síntese de fitoalexinas em sorgo, na germinação e formação de apressórios por fungos fitopatogênicos e na proteção de pepino a Colletotrichum lagenarium e sorgo a Colletotrichum sublineolum / Solange Maria Bonaldo. - - Piracicaba, 2005.

150 p. : il.

Tese (Doutorado) - - Escola Superior de Agricultura Luiz de Queiroz, 2005. Bibliografia.

1. Antracnose 2. Fitoalexina 3. Fungo fitopatogênico 4. Levedura 5. Pepino 6. Purificação 7. Sorgo I. Título 


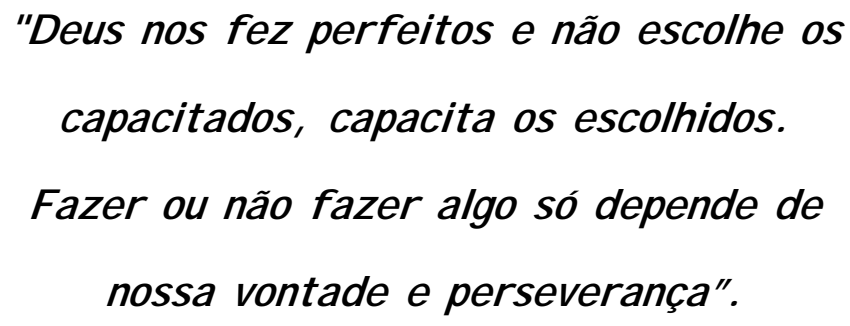

"Iá ancorado na Antártida, ouvi ruídos que pareciam de fritura. Pensei:

- será que até aqui existem chineses fritando pastéis?

Eram cristais de água doce congelada que faziam aquele som quando entravam em contato com a água salgada. O efeito visual era belissimo... Pensei em fotografar, mas falei para mim mesmo:

- Calma, vocé terá muito tempo pra isso... Xos 367 dias que se seguiram, o fenôme no não se repetiu. Algumas oportunidades são únicas." Almir Klink 
Ao meu pai, pelos 8 anos de sobriedade, ofereço.

A minha familia, fonte inesgotável de amor, força e compreensãa, dedico. 


\section{AGRADECIMENTOS}

Ao Senhor, pela benção da vida... "Sei em quem pus minha confiança..." II Timóteo 12.

Ao professor Sérgio F. Pascholati pela oportunidade, orientação, respeito e carinho com que me acolheu.

A Dra. Márcia Regina Braga pelas valiosas sugestões e atenção durante a realização do trabalho.

Ao Dr. Luiz Alberto Colnago e a Dra. Denise Osiro da EMBRAPACNPDIA pela oportunidade e ajuda na realização das análises de Infravermelho.

Aos amigos do Laboratório de Fisiologia e Bioquímica Fitopatológica: André, Eduardo Alves, Leonardo Cavalcanti, Leonardo Toffano, Patrícia Cia, Maria Cristina, Marizete, Nívea, Odair, Danilo, Paulão, Nelson, Robson e Júlio.

Ao Maurício B. Fialho, pelo carinho, amizade constante e auxílio durante o desenvolvimento do trabalho.

A Kátia R. F. Schwan-Estrada, minha "mãe científica" pela oportunidade e pelo carinho com que me acolheu e me guiou nos primeiros passos na pesquisa fitopatológica. 
Aos amigos que aqui encontrei, em especial Liliane e David, Marissônia, Ana Paula, Alexandre, Andressa, Alessandra, Carol Junqueira, Antônio, Daniele, Denise, Gilberto Rocha, Ivan, Maristela, Renata, Rock, Sílvia, Santiago e Vanessa.

As amigas que nem à distância e a ausência foram suficientes para o esquecimento, Ana Fiori, Carla Pegoraro, Luciane, Luciane Torquato, Renata Soares, Mara Lucí, Maria Eugênia, meu carinho e admiração.

Ao Eve que tem sido mais que um irmão e amigo durante todos estes anos, obrigada pelo incentivo e todo auxílio durante esta caminhada.

A Juliana, o grande presente que Deus nos deu durante esta caminhada, obrigada pelo carinho, atenção e presença quando o desânimo e as dificuldades do cotidiano se fizeram presentes.

Aos funcionários Jefferson, Fernanda, Rodolfo, Heloísa, Marise, Pedro Arthuso, Marina, Edivaldo, Carmen, Sandra, pela agradável convivência e atenção durante o transcorrer do curso.

Aos demais professores do Setor de Fitopatologia pelos conhecimentos transmitidos.

Meu agradecimento especial a todas as pessoas aqui omitidas que contribuíram para minha formação profissional e pessoal.

A CAPES pelo apoio financeiro. 


\section{SUMÁRIO}

Página

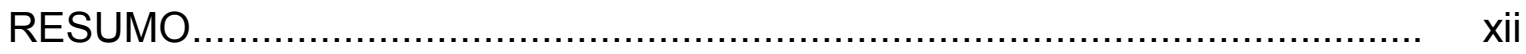

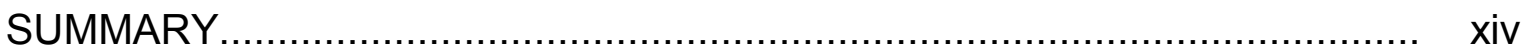

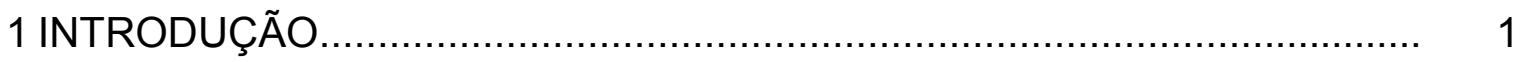

2 REVISÃO DE LITERATURA................................................................ 4

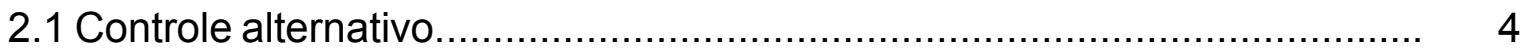

2.1.1 Indução de resistência................................................................ 5

2.2. Mecanismos de defesa da planta.................................................... 9

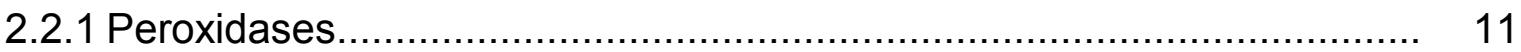

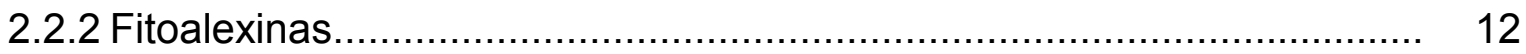

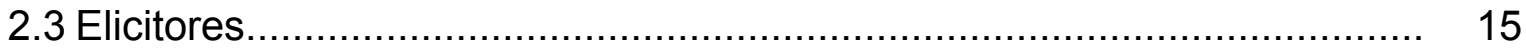

2.4 Saccharomyces cerevisiae........................................................... 17

2.4.1 Potencial de Saccharomyces cerevisiae na proteção de plantas............ 18

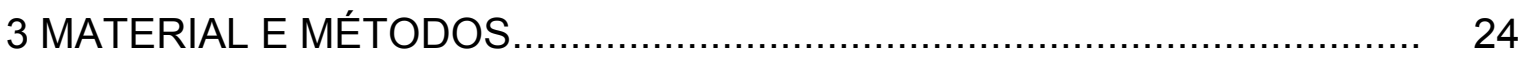

3.1 Saccharomyces cerevisiae - preparação elicitora bruta........................... 24

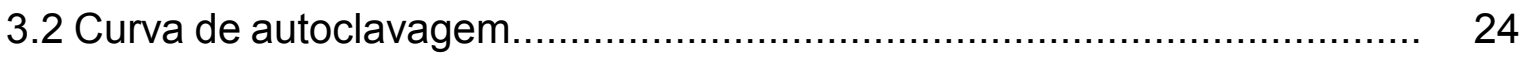

3.3 Curva dose resposta......................................................................... 26

3.4 Curva de incubação............................................................. 26

3.5 Separação dos componentes da preparação elicitora bruta através de cromatografia de troca iônica (CTI) ................................................. 26

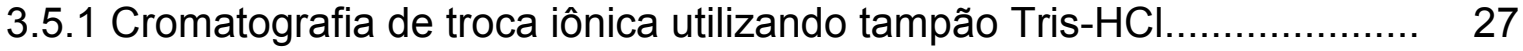

3.5.2 Cromatografia de troca iônica utilizando tampão bicarbonato de

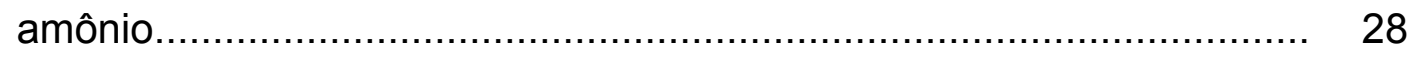

3.6 Bioensaio para produção de fitoalexinas em mesocótilos de sorgo .......... 29 
3.6.1 Obtenção de controles positivos eficientes para o bioensaio de produção de fitoalexinas em mesocótilos de sorgo

3.6.2 Efeito de antibiótico na produção de fitoalexinas em mesocótilos de sorgo

3.7 Obtenção, manutenção e preparo das suspensões de esporos dos fitopatógenos.

3.7.1 Obtenção e manutenção dos fitopatógenos.

3.7.2 Preparo das suspensões de esporos dos fitopatógenos

3.8 Efeito das preparações brutas e das frações parcialmente purificadas por CTI na germinação de esporos e formação de apressórios por fitopatógenos.

3.8.1 Bioensaio de germinação de esporos e formação de apressórios por Colletotrichum lagenarium e Colletotrichum sublineolum.

3.9 Proteção de plântulas de pepino a Colletotrichum lagenarium, em câmara de crescimento e casa-de-vegetação, utilizando as frações obtidas nas CTIs.

3.9.1 Proteção de plântulas de pepino em câmara de crescimento................. 34

3.9.2 Proteção de plântulas de pepino em casa-de-vegetação....................... 35

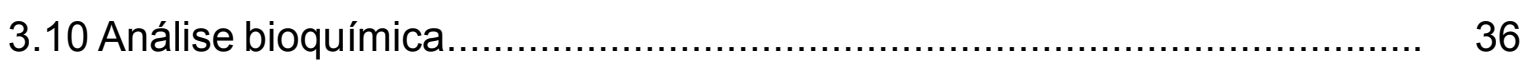

3.10.1 Atividades de peroxidases....................................................... 38

3.11 Proteção de plantas de sorgo a Colletotrichum sublineolum em casade-vegetação utilizando as frações obtidas nas CTIs............................. 38

3.12 Determinação da concentração de proteínas e carboidratos................... 42

3.13 Espectrofotometria de infravermelho............................................. 42

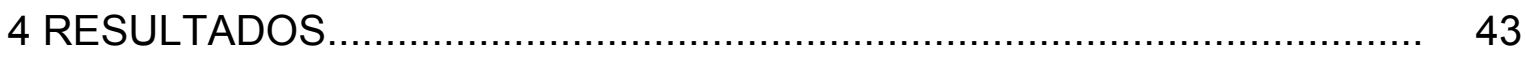

4.1 Curva de autoclavagem para extração do elicitor produzido por Saccharomyces cerevisiae.

4.2 Produção de fitoalexinas em mesocótilos de sorgo................................. 49

4.2.1 Obtenção dos controles positivos.................................................. 49

4.2.2 Efeito da adição de antibiótico na produção de fitoalexinas .................. 50 
4.2.3 Efeito de preparações de S. cerevisiae com concentração original de carboidratos na produção de fitoalexinas.

4.2.4 Efeito de preparações de S. cerevisiae com concentração reduzida de carboidratos na produção de fitoalexinas.

4.2.5 Curva dose resposta da preparação elicitora de Saccharomyces cerevisiae na produção de fitoalexinas em sorgo.

4.2.6 Produção de fitoalexinas em mesocótilos de sorgo após diferentes tempos de incubação

4.3 Germinação de esporos e formação de apressórios por Colletotrichum lagenarium e Colletotrichum sublineolum.

4.3.1 Efeito de preparações de Saccharomyces cerevisiae com concentração original de carboidratos na germinação de esporos e formação de apressórios

4.3.2 Efeito de preparações de Saccharomyces cerevisiae com concentração reduzida de carboidratos na germinação de esporos e formação de apressórios.

4.3.3 Curva dose resposta da preparação de Saccharomyces cerevisiae, autoclavada por 4 horas seqüencialmente, na germinação de esporos e formação de apressórios.

4.4 Espectrofotometria de Infravermelho.

4.5 Separação dos componentes da preparação elicitora de Saccharomyces cerevisiae por cromatografia de troca iônica

4.5.1 Produção de fitoalexinas em sorgo

4.5.2 Germinação de esporos e formação de apressórios por fitopatógenos fúngicos.

4.5.3 Proteção de plântulas de pepino a Colletotrichum lagenarium, em condições de câmara de crescimento e casa-de-vegetação, utilizando as frações obtidas nas CTIs. 
4.5.3.1 Proteção de plântulas de pepino em casa-de-vegetação e câmara de crescimento com as frações provenientes da CTI utilizando

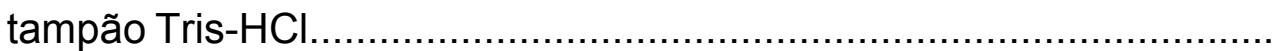

4.5.3.2 Proteção de plântulas de pepino em casa-de-vegetação com as frações provenientes da CTI utilizando tampão bicarbonato de amônio.

4.5.4 Atividade de peroxidases

4.5.5 Proteção de plantas de sorgo a Colletotrichum sublineolum em casade-vegetação utilizando as frações obtidas nas CTIs.

5 DISCUSSÃO.

5.1 Extração do elicitor presente na parede celular de Saccharomyces cerevisiae.

5.2 Espectrofotometria de Infravermelho. 102

5.3 Produção de fitoalexinas em mesocótilos de sorgo. 103

5.3.1 Efeito de preparações de Saccharomyces cerevisiae na produção de fitoalexinas em mesocótilos de sorgo.

5.3.2 Curva dose resposta na produção de fitoalexinas em mesocótilos de sorgo.

5.3.3 Produção de fitoalexinas em mesocótilos de sorgo em diferentes tempos de incubação.

5.3.4 Produção de fitoalexinas em sorgo por frações parcialmente purificadas por CTI

5.3.4.1 Produção de fitoalexinas em mesocótilos de sorgo. 107

5.3.4.2 Produção de fitoalexinas em folhas de sorgo. 109

5.4 Efeito de preparações e de frações parcialmente purificadas por CTI, obtidas de Saccharomyces cerevisiae, na germinação de esporos e formação de apressórios por Colletotrichum lagenarium e Colletotrichum sublineolum. 
5.5 Proteção de plântulas de pepino a Colletotrichum lagenarium, em câmara de crescimento e em casa-de-vegetação, utilizando as frações obtidas nas CTIs.

5.5.1 Atividade de peroxidases.

5.6 Proteção de plantas de sorgo a Colletotrichum sublineolum em casa-devegetação utilizando as frações obtidas nas CTIs.

6 CONCLUSÕES 122

REFERÊNCIAS BIBLIOGRÁFICAS. 123 APÊNDICES. 


\title{
EFEITO DE Saccharomyces cerevisiae NA SÍNTESE DE FITOALEXINAS EM SORGO, NA GERMINAÇÃO E FORMAÇÃO DE APRESSÓRIOS POR FUNGOS FITOPATOGÊNICOS E NA PROTEÇÃO DE PEPINO A Colletotrichum lagenarium E SORGO A Colletotrichum sublineolum
}

\author{
Autor: SOLANGE MARIA BONALDO \\ Orientador: Prof. Dr. SÉRGIO FLORENTINO PASCHOLATI
}

RESUMO

A levedura Saccharomyces cerevisiae tem potencial para o controle de doenças em algumas plantas, devido à capacidade de induzir resistência e de elicitar mecanismos de defesa. Entretanto, no processo de purificação de compostos elicitores presentes na parede celular de S. cerevisiae foi observado um baixo rendimento, dificultando a realização de experimentos, principalmente em campo. Assim, com o objetivo de otimizar o processo de extração do (s) elicitor (es) presentes na parede celular da levedura, células em suspensão foram autoclavadas por minutos ou horas, uma vez ou seqüencialmente. Em seguida, foi avaliado o conteúdo de carboidratos e de proteínas destas preparações que foram testadas na produção de fitoalexinas em mesocótilos de sorgo, previamente tratados ou não com abrasivo carborundum, e na germinação de conídios e formação de apressórios por Colletotrichum lagenarium e Colletotrichum sublineolum. Em função da maior concentração de 
carboidratos e da atividade elicitora em mesocótilos de sorgo, a preparação de levedura autoclavada por 4 horas seqüencialmente foi submetida ao processo de purificação. Cromatografias de troca iônica (CTI), com tampão Tris- $\mathrm{HCl}$ ou bicarbonato de amônio na eluição da coluna DEAE-Celulose, foram realizadas para separar as frações com maior poder elicitor das de baixo poder elicitor. Frações de ambas as cromatografias, induziram o acúmulo de fitoalexinas em mesocótilos de sorgo, previamente tratados ou não com abrasivo carborundum. Entretanto, frações provenientes da cromatografia com tampão bicarbonato de amônio foram capazes de inibir em $100 \%$ a germinação de conídios e a formação de apressórios dos fitopatógenos. Na proteção de pepino em câmara de crescimento, houve redução da área lesionada somente quando as plântulas de pepino receberam as frações provenientes da CTI com tampão Tris- $\mathrm{HCl}$, dois dias antes da inoculação com o patógeno. Em casa-de-vegetação, fração proveniente da CTI com tampão bicarbonato de amônio conferiu proteção às plântulas de pepino contra $C$. lagenarium, mas sem aumento na atividade de peroxidases. Plantas de sorgo tratadas com as frações de ambas as cromatografias, apresentaram tendência a uma redução da área lesionada nas folhas tratadas e folhas superiores, com produção de fitoalexinas. A maior produção de fitoalexinas em plantas de sorgo foi observada em folhas tratadas com a preparação bruta da levedura autoclavada por 4 horas seqüencialmente. Os resultados do presente trabalho indicam a existência de compostos termoestáveis na parede celular da levedura, liberados em maior concentração em função da autoclavagem seqüencial, capazes de induzir o acúmulo de fitoalexinas em mesocótilos e folhas de sorgo, com atividade antifúngica sobre $C$ sublineolum e $C$. lagenarium e potencial para induzir resistência local em pepino contra $C$. lagenarium e resistência local e sistêmica em sorgo contra $C$. sublineolum. 


\title{
EFFECT OF Saccharomyces cerevisiae IN PHYTOALEXIN SYNTHESIS IN SORGHUM, ON GERMINATION AND APPRESSORIUM FORMATION BY PLANT PATHOGENIC FUNGI AND IN THE PROTECTION OF CUCUMBER AGAINST Colletotrichum lagenarium AND SORGHUM AGAINST Colletotrichum sublineolum
}

\author{
Author: SOLANGE MARIA BONALDO \\ Adviser: Prof. Dr. SÉRGIO FLORENTINO PASCHOLATI
}

SUMMARY

The yeast Saccharomyces cerevisiae has potential in the control of diseases in some plants by the ability to induce resistance and elicits defence mechanisms. However, in the process of purification of elicitor (s) present in the cell wall of $S$. cerevisiae a low efficiency was observed during the process, making difficult to carry out experiments, mainly in field. Thus, to optimize the process of extraction of the elicitor (s) present in the cell wall of the yeast, cells in suspension were autoclaved by minutes or hours, once or in sequence. After autoclaving the carbohydrate and proteins content of these preparations were determinate and they were tested in phytoalexin accumulation in sorghum mesocotyls, previously treated or not with the abrasive carborundum, and conidia germination and appressorium formation by Colletotrichum lagenarium and Colletotrichum sublineolum. Because of the higher carbohydrate content 
and the highest elicitor activity in sorghum mesocotyls, the preparation autoclaved by 4 hours in sequence was selected for the purification process. Ion exchange chromatography (IEC) using Tris- $\mathrm{HCl}$ or ammonium bicarbonate buffer for column elution, were used to separate fractions with higher elicitation activity from those exhibiting lower elicitation activity. Fractions from the chromatography obtained using either buffer induced the accumulation of phytoalexin in sorghum mesocotyls, previously treated or not with the abrasive carborundum. However, the fractions from the chromatography with ammonium bicarbonate buffer were able to inhibit in $100 \%$ the conidia germination and appressorium formation by the phytopathogens. In the protection of cucumber in growth chamber, there was a reduction in symptoms only when the cucumber seedlings were treated with the fractions from the IEC with Tris- $\mathrm{HCl}$ buffer, two days before the inoculation with the fungus. In greenhouse, fraction from the IEC with ammonium bicarbonate buffer was able to protect cucumber seedlings against $C$. lagenarium, but without increase peroxidases activity. Sorghum plants treated with the fractions, obtained using either buffer, exhibited reduced infection in the treated leaves and leaves just above, with phytoalexin production. The highest phytoalexin production in sorghum plants was observed in leaves treated with the crude preparation of the yeast autoclaved by 4 hours sequentially. The results of the present study indicate the presence of termoestable compounds in the cell wall of the yeast, released in higher concentrations in function of the sequential autoclavage, that are able to induce phytoalexin accumulation in sorghum mesocotyls and leaves, with antifungal activity on C. sublineolum and $C$. lagenarium and potential to induce local resistance in cucumber against $C$. lagenarium and local and systemic resistance in sorghum against $C$. sublineolum. 


\section{INTRODUÇÃO}

O Brasil atualmente ocupa a oitava posição em consumo de defensivos agrícolas no mundo (Sindag, 2004), provavelmente pela elevação da produção agrícola, devido ao surgimento de novas tecnologias no campo que favoreceram a exploração de áreas antes não exploradas pela agricultura. No caso dos fungicidas, o uso indiscriminado dos mesmos, causa danos ao meio ambiente, aos seres vivos e favorece a seleção de raças resistentes de patógenos a essas substâncias químicas (Pascholati, 1998; Stangarlin et al., 1999; Ghini \& Kimati, 2000). Ao produtor o uso abusivo de produtos químicos pode acarretar além de efeitos nocivos devido ao modo incorreto de utilização, um aumento do custo de produção, diminuindo a rentabilidade da cultura (Roveratti, 1989). Em função disto, expressões como "agricultura sustentável" ou "agricultura alternativa" obtêm expressão política (Zadoks, 1992), levando cientistas do mundo inteiro a intensificarem a busca por novas medidas de proteção de plantas contra doenças.

O controle alternativo de doenças, que não inclui o controle químico tradicional e o melhoramento genético, é realizado através do controle biológico e da indução de resistência em plantas (Bettiol, 1991). O controle biológico pode ser definido como "o controle de um microrganismo através da ação direta de outro microrganismo", o qual pode atuar por meio de antibiose, parasitismo, competição, predação ou hipovirulência (Pascholati, 1998; Cook \& Baker, 1983). A resistência induzida baseia-se numa ação sobre a planta hospedeira, envolvendo a ativação de mecanismos de resistência latentes nas plantas em resposta ao tratamento com agentes bióticos ou abióticos, sendo 
que a resposta pode ser, por exemplo, o acúmulo de fitoalexinas e de proteínas relacionadas à patogênese (Pascholati, 1998). Para a ativação dos mecanismos de defesa, é necessária a presença de elicitores que são moléculas capazes de estimular respostas de defesa nas plantas (Smith, 1996), que podem ser de origem biótica ou abiótica. Os elicitores de origem biótica são derivados de tecidos vegetais ou microrganismos como fungos e bactérias (Guzzo et al., 1997; Clérivet \& Alami, 1999; Fellbrich et al., 2000; Takenaka et al., 2003), neste caso a maior parte destes elicitores purificados são carboidratos, proteínas, lipídeos, glicoproteínas, polipeptídeos (Hahn, 1996; Ricci, 1997). Os elicitores de origem abiótica são representados por metais pesados $\left(\mathrm{HgCl}_{2}\right)$ e luz ultravioleta, entre outros (Pascholati \& Leite, 1995).

Diversos trabalhos evidenciam a capacidade da levedura Saccharomyces cerevisiae como agente controlador de doenças em plantas, sendo a ação protetora promovida em função da ativação de mecanismos de defesa das plantas e a antibiose (Pascholati, 1998). Controle este que é efetivo em monocotiledôneas e em dicotiledôneas, contra patógenos fúngicos, virais e bacterianos (Lopez, 1991; Piccinin, 1995; Roveratti, 1989; Silva \& Pascholati, 1992; Stangarlin \& Pascholati, 1994). Quando aplicada em mesocótilos de sorgo estimula a produção de fitoalexinas do tipo deoxiantocianidinas (Freitas et al., 1993; Roncatto \& Pascholati, 1993); em cotilédones de soja promove o acúmulo de fitoalexinas do tipo gliceolinas; enquanto que a aplicação em folhas de sorgo promove proteção contra patógenos fúngicos (Lopez, 1991; Piccinin, 1995). Em função do efeito protetor promovido pela levedura, os trabalhos de Wulff \& Pascholati (1999) e Labanca (2002) objetivaram a purificação e caracterização bioquímica do elicitor. Os primeiros autores relatam a presença de um elicitor glicoprotéico na parede celular da levedura com capacidade de induzir a síntese de fitoalexinas em mesocótilos estiolados de sorgo, enquanto que Labanca (2002) relata a presença de um elicitor, provavelmente uma manana ligada à pelo menos uma molécula de $N$-acetilglucosamina ou a 
glucosamina, que induz resistência em pepino contra Colletotrichum lagenarium.

Entretanto, Labanca (2002) também relatou um baixo rendimento das frações parcialmente purificadas, o que dificulta a realização de testes de proteção de plantas e o uso em larga escala, levando os estudos atuais a buscar a otimização das etapas de extração e purificação da (s) molécula (s) elicitora (as) presentes na parede celular de S. cerevisiae, utilizada na panificação. Há também a necessidade de correlacionar resultados obtidos em bioensaios de mecanismos de defesa, como fitoalexinas, com a proteção de plantas em experimentos em casa-de-vegetação.

Assim, diante do exposto, o presente trabalho teve como objetivos avaliar o efeito de diferentes tempos de autoclavagem na extração da (s) molécula (s) elicitora (s) presente (s) na parede celular de S. cerevisiae; avaliar o efeito das preparações brutas e de moléculas (frações) parcialmente purificadas, obtidas a partir de S. cerevisiae, na síntese de fitoalexinas em sorgo, na germinação de esporos e formação de apressórios por Colletotrichum sublineolum e C. lagenarium; e a purificação parcial de moléculas capazes de induzir proteção em pepino contra $C$. lagenarium e em sorgo contra $C$. sublineolum. 


\section{REVISÃO DE LITERATURA}

\subsection{Controle alternativo}

O controle alternativo envolve o controle biológico e a indução de resistência, e não inclui o controle químico clássico e o melhoramento genético de plantas para resistência a doenças. As práticas de controle alternativo não fazem uso de defensivos agrícolas, embora possam estar associadas aos métodos tradicionais de controle químico e/ou de práticas culturais, a fim de aumentar sua eficiência (Moraes, 1992). Segundo Cook \& Baker (1983), o controle biológico é definido como "a redução da soma de inóculo ou das atividades determinantes da doença provocada por um patógeno, realizada por ou através de um ou mais organismos que não o homem". Sendo o mecanismo de ação dos agentes de biocontrole ilustrado através de três relações ecológicas básicas: antibiose, parasitismo e competição.

Neste contexto, encontra-se a levedura S. cerevisiae que tem sido utilizada como agente controlador de doenças, como por exemplo, em sorgo (Lopez, 1991; Piccinin, 1995), milho (Stangarlin \& Pascholati, 1994; Silva \& Pascholati, 1992) e café (Roveratti, 1989). Em milho observou-se in vivo uma redução na germinação dos conídios e na penetração do tecido foliar pelo fungo Exserohilum turcicum. Também foi observada redução no tamanho e no número médio de lesões por planta em função direta do aumento na concentração de células da levedura, e no aumento do intervalo de tempo entre a aspersão de S. cerevisiae e a inoculação com E. turcicum (Stangarlin \& Pascholati, 1994). Roveratti (1989) observou que a levedura reduziu o número 
de esporos dos patógenos que aderiram às folhas de café. Fialho (2004), trabalhando com diferentes linhagens de $S$. cerevisiae, relatou que as mesmas produzem compostos voláteis que inibem o crescimento micelial de Guignardia citricarpa, agente causal da pinta preta dos citros.

\subsubsection{Indução de resistência}

$\mathrm{Na}$ natureza resistência é regra e suscetibilidade a exceção (Agrios, 1997), pois se assim não fosse qualquer patógeno seria capaz de infectar qualquer planta e, em curto prazo os vegetais desapareceriam da face da Terra.

Segundo Margis-Pinheiro et al. (1999) as plantas não permitem, de maneira passiva, a entrada de patógenos ao interior dos tecidos. A primeira barreira que as mesmas apresentam consiste na resistência constitutiva, ou seja, aquela que ocorre mesmo sem a presença de agressores, de caráter hereditário e que as tornam imunes (resistência de não-hospedeiro) à maioria dos patógenos. Temos ainda a resistência localizada, ativada no ponto onde ocorre à agressão, e a resistência induzida, que protege a planta contra ataques subseqüentes a diversos patógenos. Portanto, as plantas apresentam mecanismos de defesa em multiplicidade e de extrema eficiência. A resistência do hospedeiro a um patógeno é definida sob o aspecto fisiológico como sendo a capacidade da planta em atrasar ou evitar a entrada e/ou a subseqüente atividade de um patógeno em seus tecidos (Heitefuss \& Williams, 1976; Goodman et al., 1986).

Segundo Pascholati (1998), as plantas possuem diferentes mecanismos estruturais e bioquímicos que podem contribuir para a resistência das mesmas contra fitopatógenos. Esses mecanismos de resistência são determinados geneticamente e a sua efetividade é dependente da expressão dos mesmos, em local e momentos adequados, magnitude adequada e 
seqüência lógica que deve ocorrer após o contato do patógeno com o hospedeiro.

Resistência sistêmica adquirida, ou indução de proteção, imunidade adquirida ou resistência induzida, envolve a ativação dos mecanismos latentes de resistência de uma planta (Hammerschmidt \& Dann, 1997). Tal ativação pode ser obtida pelo tratamento com agentes bióticos, como microrganismos viáveis ou inativados (Stangarlin \& Pascholati, 1994) ou abióticos, como ácido salicílico (Cohen, 1996; Hammerschmidt \& Dann, 1997), ácido aminobutírico (Cohen, 1996), ácido 2,6-dicloroisonicotínico (Hijwegnwn et al., 1996) e acibenzolar-S-metil $\left(\right.$ Bion $\left.^{\circledR}\right)$ (Ciba, 1995). A resistência induzida por estes tratamentos é caracterizada pela redução no tamanho ou número de lesões que se desenvolvem após a inoculação das plantas induzidas com patógenos, sendo que em fungos ocorre a deposição de barreiras estruturais, em vírus e bactérias há um decréscimo na multiplicação em resposta à infecção em plantas tratadas com indutores (Hammerschmidt, 1999). As respostas que ocorrem protegem a planta contra infecções subseqüentes com o mesmo ou então com diferentes patógenos.

A resistência induzida tem sido observada em várias plantas, incluindo dicotiledôneas e monocotiledôneas (Schneider et al., 1996). O modelo clássico para estudos de indução de resistência é o patossistema Colletotrichum lagenarium - pepino (Pascholati \& Leite, 1995).

A indução de resistência não é específica, o que é refletido não somente pelos diferentes indutores passíveis de uso, mas também pelo amplo espectro de fitopatógenos contra os quais a planta é protegida (Kuc, 1987; Sticher et al., 1997). Como por exemplo, plantas de pepino submetidas a tratamentos foliares com C. lagenarium ou vírus da necrose do fumo (TNV), como indutores, mostraram-se sistematicamente protegidas contra dez patógenos diferentes (Hammerschmidt \& Dann, 1997; Kuc, 1987).

Entretanto, quando as plantas são expostas a indutores bióticos ou abióticos e ficam protegidas contra patógenos, isso não implica que a 
indução tenha ocorrido. Segundo alguns autores, o agente de controle tanto pode estar induzindo resistência ou atuando diretamente sobre o patógeno, ou ambos ao mesmo tempo. Assim, Steiner \& Schönbeck (1995), citados por Romeiro (2002), estabeleceram critérios básicos para confirmar se a resistência apresentada pela planta foi realmente induzida ou se ela se deve a outros fatores que, de alguma forma contribuíram para reduzir a incidência e/ou a severidade da doença. Os critérios propostos são os seguintes:

a) Ausência de efeitos tóxicos do agente indutor sobre o patógeno desafiante;

b) Supressão da resistência induzida pela exposição prévia da planta a substâncias que inibem a expressão de genes do hospedeiro;

c) Necessidade de um intervalo de tempo entre a exposição da planta ao indutor e a expressão da resistência;

d) Não haver uma relação entre magnitude da resistência expressa e quantidades crescentes do indutor aplicado, à semelhança do que se observa em casos típicos de uso de defensivos;

e) Inespecificidade de proteção;

f) A resistência deve ser local e sistêmica;

g) A resistência deve ser dependente do genótipo da planta.

Segundo Pascholati \& Leite (1995), e como comentado acima, o fenômeno da proteção induzida é dependente do intervalo de tempo que ocorre entre o tratamento com o indutor e a inoculação do patógeno. Assim, essa dependência indica que mudanças específicas no metabolismo da planta, que envolvem a síntese e/ou acúmulo de substâncias são importantes no fenômeno da resistência induzida.

O avanço nas pesquisas envolvendo a resistência induzida em plantas é acompanhado pelo surgimento de novos produtos comerciais com maior eficácia, maior estabilidade e menor impacto ao ambiente. Produtos estes que podem propiciar em alguns casos, além da redução de perdas ocasionadas por patógenos, incrementos no desenvolvimento vegetativo propiciando então melhora na produtividade. Desde o surgimento do acibenzolar-S-metil (Bion ${ }^{\circledR}$ ) 
vários produtos como Messenger ${ }^{\circledR}$, Elexa ${ }^{\circledR}$, Oxycom ${ }^{\circledR}$, fosfitos e silicatos representam uma nova geração de defensivos que exploram de modo geral a capacidade de ativação de diferentes mecanismos de defesa na planta, com alto potencial para uso em programas de manejo de doenças de plantas (Resende et al., 2004).

Recentemente a indução de resistência passou a ser bastante estudada também em pós-colheita, avaliando os mecanismos de resistência ativados no tecido vegetal, como $\beta-1,3$ glucanases, quitinases e fitoalexinas. Estes estudos podem representar um avanço nos métodos de controle nesta fase, podendo reduzir ou eliminar a utilização de defensivos agrícolas (Pascholati et al., 2004). Segundo Dantas et al. (2004), frutos e vegetais tratados com indutores de resistência intensificam uma reação de defesa antes da invasão dos microrganismos, desencadeando uma resposta de defesa à infecção.

Provavelmente a resistência induzida contra doenças através de ativadores químicos, como acibenzolar-S-Metil e Messenger ${ }^{\circledR}$, por exemplo, ou por outros meios, como rizobactérias promotoras de crescimento ou elicitores oriundos de fungos e bactérias, se torne um componente importante dos programas de manejo de doenças, particularmente nos casos onde os métodos atuais de controle mostram-se pouco efetivos (Hammerschmidt \& Dann, 1997), bem como no controle de doenças de pós-colheita envolvendo frutas e hortaliças.

Apesar dos grandes avanços das pesquisas nos últimos anos sobre a indução de resistência em plantas, algumas questões ainda permanecem sem respostas, como, por exemplo, como ocorre a translocação dos sinais e qual sinal é translocado no floema; e com certeza os grandes avanços na biologia molecular deverão colaborar com a solução de tais questões e estimular o uso da indução de resistência como um eficiente método de controle de fitopatógenos. 
A seguir, serão abordados alguns mecanismos ou substâncias de defesa das plantas que se encontram envolvidos na resposta de resistência, dando ênfase para fitoalexinas e peroxidases que foram objeto de estudo no corrente trabalho.

\subsection{Mecanismos de defesa da planta}

Os mecanismos de defesa (bioquímicos e estruturais) são divididos em pré-formados, e pós-formados, sendo que os últimos é que se mostram de interesse dentro do fenômeno da indução de resistência (Pascholati, 1998). Segundo Pascholati \& Leite $(1994,1995)$ os mecanismos de defesa compreendem: 1) Mecanismos pré-formados (defesas constitutivas ou passivas): englobam os mecanismos de defesa presentes nas plantas antes do contato das mesmas com o patógeno. Podem ser: a) estruturais: cutícula, tricomas, estômatos, fibras/vasos condutores; b) bioquímicos: fenóis, alcalóides glicosídicos, lactonas insaturadas, glicosídeos fenólicos e cianogênicos, inibidores protéicos, fototoxinas, quitinases e $\beta-1,3$ glucanases; 2) Mecanismos pós-formados (defesas induzíveis ou ativas): encontram-se ausentes ou presentes em baixos níveis antes da infecção, sendo produzidos em resposta à presença do patógeno. Podem ser: a) estruturais: papilas, halos, lignificação, camadas de cortiça, camada de abscisão e tiloses; b) bioquímicos: espécies ativas de oxigênio, fitoalexinas e proteínas relacionadas à patogênese (como quitinase e $\beta-1,3$ glucanases). Dentre os diferentes mecanismos de resistência existentes na planta, procuramos ilustrar na Tabela 1 alguns que podem ser ativados durante a indução de resistência em interações indutor-hospedeiroprovocador.

Segundo Stangarlin (1995) a resistência é o resultado de um conjunto de eventos que ocorrem de forma harmoniosa nas plantas e nada 
impede que mecanismos de defesa considerados como constitutivos, possam ser sintetizados e acumulados na interação planta-patógeno.

Tabela 1. Exemplos de mecanismos de defesa ativados em plantas exibindo resistência induzida (modificado de Schönbeck, 1996, citado por Pascholati, 1998)

\begin{tabular}{|c|c|c|c|}
\hline Classificação & $\begin{array}{c}\text { Interação } \\
\text { hospedeiro-patógeno }\end{array}$ & Indutor & $\begin{array}{l}\text { Mecanismos de } \\
\text { defesa }\end{array}$ \\
\hline \multirow{3}{*}{$\begin{array}{l}\text { Mudanças } \\
\text { estruturais }\end{array}$} & $\begin{array}{c}\text { Pepino } x \\
\text { Colletotrichum } \\
\text { lagenarium }\end{array}$ & C. lagenarium & $\begin{array}{l}\text { Papilas e } \\
\text { Lignificação }\end{array}$ \\
\hline & $\begin{array}{c}\text { Arroz x Pyricularia } \\
\text { oryzae }\end{array}$ & Probenazole & $\begin{array}{c}\text { Lignificação e } \\
\mathrm{RH}^{*}\end{array}$ \\
\hline & $\begin{array}{c}\text { Tomate } x \text { Fusarium } \\
\text { oxysporum }\end{array}$ & Endomicorriza & Lignificação \\
\hline \multirow{2}{*}{$\begin{array}{l}\text { Compostos } \\
\text { antifúngicos }\end{array}$} & $\begin{array}{c}\text { Cevada } \times \text { Erysiphe } \\
\text { graminis }\end{array}$ & B. subtilis, INA** & Tionina \\
\hline & $\begin{array}{c}\text { Fumo } \mathrm{x} \\
\text { Peronospora } \\
\text { tabacina }\end{array}$ & P. tabacina & Fitoalexinas \\
\hline \multirow{3}{*}{$\begin{array}{l}\text { Proteínas de } \\
\text { defesa }\end{array}$} & $\begin{array}{l}\text { Pepino } \times C \text {. } \\
\text { lagenarium }\end{array}$ & $\begin{array}{l}\text { C. lagenarium } \\
\text { fosfatos, oxalato }\end{array}$ & $\begin{array}{c}\text { Quitinase } \\
\beta-1,3-\text { qlucanase }\end{array}$ \\
\hline & & INA & Peroxidases \\
\hline & Fumo $\times$ P. tabacina & P. tabacina; TMV & $\begin{array}{l}\text { Proteínas-RP } P^{* * *} \text { e } \\
\text { Lipoxigenase }\end{array}$ \\
\hline
\end{tabular}

${ }^{*} \mathrm{RH}=$ reação de hipersensibilidade

**Ácido dicloroisonicotínico

${ }^{* * *}$ Proteínas-RP $=$ proteínas relacionadas à patogênese 


\subsubsection{Peroxidases}

Peroxidases, enzimas antioxidantes, estão presentes nos tecidos das plantas (Hoagland, 1990), em certas células animais (Lück, 1965) e em microrganismos (Kosugue, 1969), participando em vários processos fisiológicos de grande importância (Misaghi, 1982) e freqüentemente envolvidas na lignificação das células de plantas em resposta a infecções por patógenos (Mander \& Fussi, 1982).

Mudanças na atividade das peroxidases são correlacionadas com resposta de resistência ou suscetibilidade em diferentes patossistemas como, melão - C. lagenarium (Grand \& Rossignol, 1983); batata - Erwinia carotovora (Lojkowska \& Holobowska, 1992); fumo - P. tabacina (Ye et al., 1990); alface Bremia lactucae (Reuveni et al., 1991) e feijão - Uromyces viciae-fabae (Bonatti et al., 1994).

$\mathrm{Na}$ proteção de plantas através da indução de resistência normalmente se observa alteração na atividade das peroxidases, que apresenta participação na resistência vegetal contra fitopatógenos. Por exemplo, Labanca (2002) relatou aumento na atividade de peroxidases no patossistema pepino-C. lagenarium, utilizando a levedura S. cerevisiae como agente indutor. Di Piero (2003) observou acréscimos da atividade de peroxidases neste mesmo patossistema, mas quando as plantas foram previamente tratadas com extratos aquosos de basidiocarpos de Lentinula edodes (shiitake) e Agaricus blazei (cogumelo-do-sol). O mesmo autor relatou que em tomateiro o extrato aquoso de $A$. blazei pode induzir resistência contra $X$. campestris pv. vesicatoria, porém a atividade de peroxidases não foi alterada neste patossistema.

Quando plântulas de feijão foram tratadas com espécies não patogênicas de Rhizoctonia houve redução em 80 a 100\% da podridão da raiz causada por $R$. solani e $38 \%$ de redução da antracnose causada por $C$. lindemuthianum, com aumento na atividade de enzimas como peroxidases, $\beta$ 1,3 glucanases e quitinases (Xue et al., 1998). Campos et al. (2004) 
observaram acréscimos nas atividades de peroxidases e polifenoloxidase em plantas de feijão previamente tratadas com ácido salicílico e com a raça delta de $C$. lindemuthiamum (fungo indutor) e inoculadas com patótipo virulento de $C$. lindemuthianum após três dias do tratamento indutor.

Segundo $\mathrm{He}$ et al. (2002), plantas de aspargo tratadas com o isolado não patogênico de Fusarium oxysporum apresentaram proteção contra o isolado patogênico $F$. oxysporum f. sp. asparagi com um rápido aumento na atividade de peroxidases, em relação às plantas de aspargo não tratadas. Stadnik \& Buchenauer (2000) observaram aumento de peroxidase e outras enzimas, associada à indução de resistência, numa cultivar suscetível de trigo quando as plantas foram tratadas com acibenzolar-S-metil e inoculadas com o patógeno Blumeria graminis f.sp. tritici.

Para Labanca (2002), embora as peroxidases não possam ser utilizadas como marcadores de resistência, alterações na sua atividade ou no perfil eletroforético de suas isoformas é um indício de metabolismo alterado. Assim, alterações na atividade de peroxidases envolvem também alteração na atividade de outras enzimas presentes na mesma rota metabólica. Portanto, as peroxidases são usadas em estudos de indução de resistência, não como um marcador, mas sim como uma das muitas respostas manifestadas pelas plantas.

\subsubsection{Fitoalexinas}

Fitoalexinas são compostos secundários, antimicrobianos, de baixa massa molecular e sintetizados pelas plantas em resposta a estresses físicos, químicos ou biológicos. São capazes de impedir ou reduzir a atividade de agentes patogênicos, sendo a taxa de acúmulo dependente dos genótipos do hospedeiro e/ou patógeno (Purkayastha, 1995). O envolvimento das fitoalexinas nas respostas de resistência das plantas contra patógenos vêm sendo estudado por mais de quatro décadas (Daniel \& Purkayastha, 1995). 
Segundo Ebel (1986) as fitoalexinas englobam diversas classes de produtos naturais, com mais de 300 fitoalexinas caracterizadas, em diferentes classes de compostos químicos como benzofurano, cumarina, dihidrofenantreno, diterpeno, flavonóide, furanoacetileno, isocumarina, isoflavonóide, poliacetileno, pterocarpano, sesquiterpeno, stilbeno e triterpeno, (Smith, 1996). Atualmente sabe-se que mais de 100 espécies de plantas, dentro de 21 famílias, são capazes de produzir algum tipo de fitoalexina.

As fitoalexinas agem sobre fungos, bactérias, vírus, células vegetais e animais, sendo ativas em concentrações da ordem de $10^{-5}$ a $10^{-4} \mathrm{M}$ (Smith, 1982; Ebel, 1986). De modo geral, a forma de ação das fitoalexinas sobre os fungos inclui granulação citoplasmática, desorganização dos conteúdos celulares, ruptura da membrana plasmática e inibição de enzimas fúngicas. Estes efeitos citológicos refletem-se na inibição da germinação, desidratação ou elongação do tubo germinativo e redução ou inibição do crescimento micelial (Hipskind et al., 1990; Lo et al., 1996; Smith, 1996; Aguero et al., 2002).

A produção de fitoalexinas em sorgo ocorre em inclusões citoplasmáticas próximas ao local da tentativa de penetração do fungo. Essas inclusões se movem em direção ao sítio de infecção e despejam seu conteúdo no citoplasma, interferindo com o desenvolvimento do patógeno (Snyder \& Nicholson, 1990). Nas interações incompatíveis utilizando cultivares resistentes inoculadas com $C$. sublineolum ocorre à produção de um complexo de compostos fenólicos, dentre os quais foram identificadas quatro fitoalexinas do tipo deoxiantocianidinas: luteolinidina, 5-metoxiluteolinidina, apigeninidina e éster do ácido cafeico de arabinosil 5-O-apigeninidina, que são produzidas na fase de pré-infecção (formação da vesícula de infecção) (Lo et al., 1999; Wharton \& Nicholson, 2000). Enquanto que nas interações compatíveis em cultivares inoculadas com o mesmo fungo houve o acúmulo de duas fitoalexinas (apigeninidina e éster do ácido cafeico de arabinosil 5-O-apigeninidina) (Hipskind et al., 1990; Lo et al., 1996; Nicholson et al., 1987), sendo que a 
síntese ocorre somente no início da fase de infecção (formação das hifas primárias) e não há produção de luteolidinina nem de metoxiluteolidinina, que são as fitoalexinas de maior fungitoxicidade e as primeiras a serem sintetizadas (Lo et al., 1999; Wharton \& Nicholson, 2000).

Segundo Tenkouano et al. (1993), as fitoalexinas podem servir como uma ferramenta para detecção mais precoce da resistência a $C$. sublineolum, uma vez que cultivares que apresentam resistência a antracnose expressam altos conteúdos de fitoalexinas do que cultivares suscetíveis. Uma hipótese é que as cultivares suscetíveis produzem fitoalexinas em todos os estádios, mas os compostos somente se acumulam em níveis fungitóxicos em plantas juvenis.

A síntese destas fitoalexinas em sorgo ocorre em ordem cronológica, tanto em relações compatíveis como em relações incompatíveis entre sorgo e $C$. sublineolum, sendo que a fitoalexina metoxiluteolinidina apresenta efeito fungitóxico sobre a germinação de conídios e na formação de apressórios deste patógeno (Lo et al., 1999; Wharton \& Nicholson, 2000). Hipskind et al. (1990), constataram em bioensaios conduzidos com as fitoalexinas de sorgo purificadas, que a germinação e a formação de apressórios por C. sublineolum foram inibidos por luteolinidina em concentrações menores que $2,5 \mu \mathrm{mol}$. Outros estudos sugerem que as fitoalexinas podem restringir $o$ desenvolvimento fúngico através da fitotoxicidade aos tecidos da planta, envolvendo a morte celular do hospedeiro e o acúmulo de outros produtos tóxicos (Nicholson \& Hammerschmidt, 1992).

Em cana-de-açúcar foi encontrada uma deoxiantocianidina, luteolinidina, que atua como inibidora de crescimento fúngico, embora seu papel na resistência não tenha sido estudado (Godshall \& Lonergan, 1987). A indução para produção dessas fitoalexinas pode ocorrer em resposta à penetração fúngica (Snyder et al., 1991), ao tratamento com elicitores bióticos (Yamaoka et al., 1990; Wulff, 1997) ou abióticos (Freitas et al., 1993) ou ferimentos (Lopez \& Pascholati, 1992). Estas fitoalexinas são sintetizadas em mesocótilos 
(Nicholson et al., 1987) e em folíolos (Nicholson et al., 1988), em torno de 3 horas após a tentativa de penetração fúngica; podendo ocorrer na epiderme e hipoderme (Nicholson et al., 1988; Snyder et al., 1991).

Mesocótilos estiolados de sorgo (Nicholson et al., 1987; Wulff, 1997) apresentam-se como excelentes ferramentas para estudos envolvendo a ação elicitora de moléculas de origem biótica e abiótica.

\subsection{Elicitores}

O termo elicitores foi inicialmente proposto por Keen (1975) para denominar moléculas ou substâncias que estimulavam a síntese de fitoalexinas, mas atualmente, são considerados elicitores moléculas (fatores) que estimulam qualquer resposta de defesa nas plantas e podem ser classificados quanto à origem, em bióticos ou abióticos (Ebel, 1986; Hahn, 1996; Smith, 1996). Porém, essas categorias se sobrepõem à medida que as substâncias de origem biológica vão sendo sintetizadas em laboratório (Resende et al., 2002a).

Luz ultravioleta, íons metálicos e moléculas orgânicas sintetizadas em laboratório podem ser classificados como elicitores abióticos (Pascholati e Leite, 1994). Os elicitores bióticos apresentam natureza química variada, como carboidratos (oligossacarídeos) (Ayers et al., 1976ab; Okinaka et al., 1995), glicoproteínas (Basse \& Boller, 1992; De Witt \& Roseboom, 1980; Farmer \& Helgeson, 1987; Parker et al., 1991; Roby et al., 1985; Schaffrath et al., 1995; Wulff, 1997), proteínas (Gustine et al., 1995; Ricci et al., 1989), oligopeptídeos (Hahlbrock et al., 1995; Nürnberger et al., 1994), ácidos graxos (Bostock et al., 1981) e componentes da parede celular vegetal (Davis et al., 1986; Hahn et al., 1981). A variação na natureza química dos elicitores demonstra que não há

uma característica estrutural única que possa ser considerada como determinante da atividade elicitora (Smith, 1996). Porém, características estruturais são importantes no reconhecimento dos elicitores pela planta e 
pequenas variações em sua estrutura interferem na atividade biológica (Sharp et al., 1984). Segundo Davis et al. (1986) e Dixon \& Lamb (1990), a ativação dos mecanismos de defesa pelos elicitores pode ocorrer também de maneira sinergística, onde a resposta pode sofrer uma magnificação pela atuação de dois fatores ou moléculas (elicitores).

Elicitores bióticos podem ainda ser classificados em endógenos, como fragmentos da própria planta, liberados pelo ataque de enzimas (Davis et al., 1986; Hahn et al., 1981), ou exógenos como fragmentos do patógeno (Ayers et al., 1976ab; Gustine et al., 1995; Okinaka et al., 1995; Schaffrath et al., 1995). Sendo que os elicitores exógenos podem ainda ser classificados em específicos e não-específicos. Os elicitores específicos são aqueles que induzem algum tipo de resposta de defesa em variedades incompatíveis, no contexto da interação gene-a-gene, sendo normalmente o produto do gene avr ou o resultado da ação ou degradação do produto desse gene (Resende et al., 2002a). Segundo este mesmo autor, elicitores não-específicos são aqueles que induzem uma reação de defesa em diferentes espécies ou variedades de plantas, e a ocorrência deste elicitor implica no estímulo de mecanismos gerais de defesa em plantas e que não se enquadram no tipo de resistência gene-agene, como no caso dos elicitores específicos.

Os elicitores podem atuar como indutores de resistência através da ativação de resposta (s) de defesa (s). O elicitor purificado de Pyricularia oryzae induz lignificação com redução dos sintomas ocasionados pelo patógeno (Schaffrath et al., 1995). Também proteínas de baixa massa molecular denominadas elicitinas, secretadas por Phytophthora spp., são translocadas no vegetal, estimulando necrose e induzindo resistência (Kamoun et al., 1993; Keller et al., 1996; Ricci et al., 1989).

A hidrólise e a solubilização em água, com a presença ou ausência de calor, são alguns dos métodos que permitem a extração de elicitores de microrganismos ou plantas (Guzzo, 1989; 1997; Slováková et al., 2000; Schweizer et al., 2000). Precipitação etanólica, cetônica ou com sulfato 
de amônio e seqüência de cromatografias são etapas empregadas durante a purificação de elicitores (Hahn \& Albersheim, 1978; Koch et al., 1998; Schaffrath et al., 1995; Wulff \& Pascholati, 1999; Labanca, 2002). Segundo Labanca (2002), a obtenção de um elicitor puro pode ter várias finalidades, dentre as quais o estudo de sinalização e até mesmo a busca por um produto que possa ser usado como indutor de resistência comercial, bem como a separação de compostos supressores que estejam presentes em extratos brutos, que venham a interferir com a atividade do elicitor (Shiraishi et al., 1997; Wulff \& Pascholati, 1999).

\subsection{Saccharomyces cerevisiae}

Saccharomyces cerevisiae é um fungo ascomiceto que produz ascos sem a produção de ascocarpos e o crescimento da colônia se dá por brotação das células, não produzindo micélio (Agrios, 1997; Isaac, 1992). Está incluída na ordem Sccharomycetales e apresenta tamanho médio de $5 \mu \mathrm{m}$. Seu habitat natural é a superfície das frutas, porém tem sido utilizada pelo homem para a produção de bebidas alcoólicas, etanol e na panificação. Normalmente nestes processos a função da levedura é apenas como um agente biológico de transformação, uma vez que ao final do processo produtivo é descartada sendo considerada como subproduto. Assim, se faz necessária uma busca por novas aplicações deste organismo após a sua utilização em processos primários (Fialho, 2004).

Com relação à parede celular, esta se mostra com espessura variando de 70 a $200 \mathrm{~nm}$, sendo constituída de uma camada externa principalmente de manoproteínas (polímeros de manose ligados a proteínas); com alguma quantidade de quitina; uma camada intermediária de glucana, que forma um material fibrilar, o qual confere rigidez à célula. $E$ finalmente uma camada interna aparentemente com um conteúdo maior de proteínas. Segundo 
alguns autores, citados por Assis (1996), a parede pode representar cerca de $14-30 \%$ da massa celular total, sendo constituída principalmente por $40 \%$ de $\beta$ glucanas, $40 \%$ de $\alpha$-mananas, $8 \%$ de proteínas, $7 \%$ de lipídios, $3 \%$ de substâncias inorgânicas e $2 \%$ de hexosaminas e quitina. Noventa por cento da quitina está presente na cicatriz originada pela divisão celular. A quitina da levedura é um polímero de $N$-acetilglucosamina (em ligação $\alpha-1,4$ ) que ocorre na sua forma a sendo de difícil extração (Cabib et al., 1982).

Atualmente se aceita que o principal polissacarídeo de $S$. cerevisiae é a glucana, com ligações $\beta-(1,3)$ e ramificações $\beta-(1,6)$, a qual exibe propriedades imunoestimulantes em animais. As proteínas presentes na parede, normalmente na forma de glucoproteínas ou manoproteínas, podem exibir funções estruturais (tendo glucosamina como agente de ligação entre a proteína e o polissacarídeo) ou enzimáticas (por exemplo, invertase, glucanase, protease). A atividade das enzimas extracelulares da levedura pode também ser observada na parede e espaços periplásmicos, espaço entre a parede e a membrana plasmática.

Shibata et al. (1983), citam que as manoproteínas estão complexadas com fósforo, formando um complexo fosfomanoproteína. Estes polímeros apresentam dois componentes: um neutro, contendo pouco ou nenhum fosfato e outro ácido, contendo pequenas quantidades de fosfato e nitrogênio peptídico (Okubo et al., 1978).

\subsubsection{Potencial de Saccharomyces cerevisiae na proteção de plantas}

Estudos apontam para a possibilidade da levedura S. cerevisiae induzir mecanismos de defesa não específicos (Benhamou \& Lafontaine, 1995; Hahn \& Albersheim, 1978; Roncatto \& Pascholati, 1998; Wulff \& Pascholati, 1999; Labanca, 2002), sendo provável que a resistência induzida por $S$. cerevisiae esteja ligada à presença de determinados carboidratos e 
glicoproteínas presentes na parede celular (Hahn \& Albersheim, 1978; Wulff \& Pascholati, 1999; Labanca, 2002).

Os primeiros pesquisadores a demonstrarem a possibilidade da proteção de plantas pelo uso da levedura foram Martins e colaboradores (Martins et al., 1986; Martins, 1991); quando evidenciaram que a aplicação de filtrados obtidos de extrato de S. cerevisiae sobre folhas destacadas de cafeeiro 72 horas antes da inoculação com o patógeno Hemileia vastatrix, agente causal da ferrugem alaranjada, induzia resistência ao patógeno sem afetar a germinação dos urediniósporos e a formação de apressórios.

Roveratti (1989), trabalhando com células vivas ou autoclavadas da levedura, mostrou que ocorria proteção de plantas de café com um ano de idade somente quando as preparações de $S$. cerevisiae eram aplicadas antes ou simultaneamente com $H$. vastatrix. Segundo a autora, a proteção aparentemente era devida a dois mecanismos distintos; um mecanismo que promovia a diminuição do número de urediniósporos na superfície da folha e outro que inibia a germinação dos mesmos, provavelmente por antibiose. Martins \& Moraes (1996) demonstraram a ocorrência de resistência sistêmica em plantas de café suscetíveis aspergidas com filtrado de S. cerevisiae, quando observaram o desenvolvimento do fungo nos tecidos durante um período de 228 horas após a inoculação. A expressão da resistência foi detectada entre 4872 horas após a inoculação, ocorrendo no híbrido resistente no estágio de uma célula mãe do haustório. No material suscetível induzido ocorria no estágio de segunda célula mãe do haustório. Os autores concluíram que a levedura age sobre $H$. vastatrix através de duas maneiras: na primeira, impede que uma percentagem de urediniósporos tenha sucesso em penetrar e infectar a planta, enquanto que na segunda, agindo sobre o hospedeiro, induz o mesmo a expressar os mecanismos de resistência, ocasionando o aborto das colônias resultantes dos esporos que penetraram na planta.

Reglinski et al. (1994a), observaram que o uso de extratos obtidos da levedura proporcionou uma redução em torno de $90 \%$ da infecção por $E$. 
graminis nas folhas de cevada, bem como a formação de papilas e aumentos na atividade da fenilalanina amônia-lise. Em experimentos de campo, Reglinski et al. (1994b) observaram uma redução da infecção, porém em menor grau do que o observado em condições de laboratório tendo conduzido inclusive a aumentos na produção de grãos de diferentes cultivares de cevada.

Lyon et al. (1995ab), trabalhando com os patossistemas alface Botrytis cinerea/Rhizoctonia solani e feijão - B. fabae, observaram que quando discos de folhas foram tratados com extratos de $S$. cerevisiae a resistência dos mesmos aos patógenos aumentava, sendo evidenciada como uma redução na infecção.

Cheah et al. (1995ab), observaram que o isolado S20 de S. cerevisiae, utilizado na indústria alimentícia, reduzia em $100 \%$ a podridão de limões causada por Penicillium digitatum e em 51\% a podridão em abobrinha causada por Fusarium sambucium. Os mesmos autores relataram que em frutos de kiwi houve redução de $61 \%$ da incidência da podridão causada por Botrytis cinerea e que este controle derivado da levedura estaria relacionada a competição por espaço e nutrientes.

Cia et al. (2004), demonstraram o potencial de S. cerevisiae na redução da incidência da antracnose em frutos de mamão, quando a levedura foi aplicada 24 horas antes da inoculação com o patógeno C. gloesporioides, provavelmente pela ativação de algum mecanismo de resistência nos tecidos dos frutos.

Estudos atuais demonstram o emprego de indutores provenientes de S. cerevisiae em condições de campo. Dantas et al. (2004), observaram que o uso de um indutor biótico, o Agro-Mos ${ }^{\circledR}$ que tem na sua composição um mananoligossacarídeo fosforilado derivado da parede celular de S. cerevisiae 1026, mostrou-se eficiente no controle de antracnose em mamão quando o tratamento indutor foi realizado em pré-colheita e pós-colheita. 
O potencial do uso de S. cerevisiae na proteção de plantas também foi observado em trabalhos realizados no Laboratório de Fisiologia e Bioquímica Fitopatológica (Esalq/USP) (Tabela 2).

Recentemente foi demonstrado o efeito de suspensões de células dessa levedura (linhagem de panificação), bem como do filtrado dessas suspensões a proteção de plantas de sorgo contra C. sublineolum e E. turcicum (Lopez, 1991; Piccinin, 1995), milho contra C. graminicola e E. turcicum (Silva \& Pascholati, 1992; Stangarlin \& Pascholati, 1994), maracujá contra Xanthomonas campestris pv. passiflora (Piccinin, 1995) e eucalipto contra B. cinerea (Piccinin, 1995). A proteção de plantas de sorgo contra C. sublineolum e E. turcicum também foi demonstrada em campo, sendo a produção de grãos por parte das plantas protegidas próxima da produção exibida pelas plantas tratadas com fungicida (Piccinin, 1995; Piccinin et al., 2005).

Os trabalhos de purificação mostraram que a fração do filtrado com atividade protetora é termolábil, com peso molecular superior a 12-14 x $10^{3}$ daltons e uma proporção de $72 \%$ de carboidratos para $28 \%$ de proteínas, além da capacidade de elicitar a síntese da fitoalexina gliceolina em cotilédones de soja (Lopez, 1991). Preparações de S. cerevisiae exibiram também a capacidade de alterar o metabolismo de plantas de sorgo no tocante ao conteúdo de pigmentos, fitoalexinas do tipo deoxiantocianidinas, proteínas totais, fenóis totais, carboidratos totais e enzimas (Freitas et al., 1993; Lopez, 1991; Roncatto \& Pascholati, 1993). Resultados mais recentes evidenciaram a obtenção de elicitores glicoprotéicos de $S$. cerevisiae, os quais estimulam o acúmulo de fitoalexinas em mesocótilos de sorgo (Wulff \& Pascholati, 1998), sendo solúveis em etanol 50\%, ligam-se à resina aniônica DEAE-Celulose e o tratamento com proteinase reduz a atividade elicitora (Wulff \& Pascholati, 1999). Além das moléculas elicitoras, foram fracionadas moléculas que possuem a capacidade de suprimir o acúmulo de fitoalexinas pelas moléculas elicitoras (Wulff \& Pascholati, 1999). Labanca (2002) relatou a presença de um elicitor, provavelmente uma manana ligada à pelo menos uma molécula de $\mathrm{N}$ - 
acetilglucosamina ou a glucosamina, que conferia proteção a plantas de pepino contra $C$. lagenarium, porém frações parcialmente purificadas da levedura promoviam aumento da esporulação do patógeno in vitro sem afetar o crescimento micelial do mesmo.

Com base no exposto acima, em função do volume de informações gerada nos últimos anos sobre o uso potencial da levedura de panificação $S$. cerevisiae no controle de fitopatógenos, bem como a fácil aquisição da levedura, as pesquisas deverão se concentrar no isolamento e na caracterização da (s) molécula (s) elicitora (s) obtida (s) desse microrganismo, aptos a induzir o acúmulo de fitoalexinas em sorgo, e de induzir resistência em plantas de pepino e sorgo, bem como avaliar o efeito direto desta (s) molécula (s) elicitora (s) sobre fitopatógenos. 
Tabela 2. Resultados de estudos conduzidos junto ao Laboratório de Fisiologia e Bioquímica Fitopatológica - ESALQ/USP - sobre os efeitos de Saccharomyces cerevisiae em fitopatógenos e na manifestação de sintomas em diferentes interações planta-patógeno, sob condições de laboratório/casa-de-vegetação/campo

\begin{tabular}{|c|c|c|}
\hline CULTURA & PATÓGENO & CONCLUSÕES \\
\hline & $\begin{array}{l}\text { Colletotrichum } \\
\text { sublineolum (in vitro) }\end{array}$ & $\begin{array}{l}\text { Inibição da germinação de conídios pelo extrato de } \\
\text { levedura e pelo filtrado do extrato. Redução do } \\
\text { crescimento micelial. }\end{array}$ \\
\hline & $\begin{array}{l}\text { Exserohilum turcicum } \\
\text { (in vitro) }\end{array}$ & $\begin{array}{l}\text { Inibição da germinação de conídios pela } \\
\text { suspensão de células da levedura e inibição } \\
\text { parcial de germinação de conídios pelo filtrado da } \\
\text { suspensão. }\end{array}$ \\
\hline Milho & $\begin{array}{l}\text { Colletotrichum } \\
\text { sublineolum (casa-de- } \\
\text { vegetação) }\end{array}$ & $\begin{array}{l}\text { Redução da área foliar lesionada e de número de } \\
\text { lesões. Perda do poder de redução } 24 \mathrm{~h} \text { após a } \\
\text { aplicação da levedura. Autoclavagem leva à perda } \\
\text { total da capacidade inibitória. }\end{array}$ \\
\hline Milho & $\begin{array}{lr}\text { Exserohilum } & \text { turcicum } \\
\text { (câmara } & \text { de } \\
\text { crescimento) }\end{array}$ & $\begin{array}{l}\text { Redução no tamanho das lesões e no número de } \\
\text { lesões por planta. }\end{array}$ \\
\hline Sorgo & $\begin{array}{l}\text { Colletotrichum } \\
\text { sublineolum (casa-de- } \\
\text { vegetação) }\end{array}$ & Redução na severidade da doença. \\
\hline Eucalipto & $\begin{array}{lr}\text { Botrytis } & \text { cinerea } \\
\text { (câmara } & \text { de } \\
\text { crescimento) } & \end{array}$ & Proteção de mudas. \\
\hline Maracujá & $\begin{array}{l}\text { Xanthomonas } \\
\text { campestris } \\
\text { passiflora } \\
\text { vegetação) }\end{array}$ & $\begin{array}{l}\text { Redução do número de lesões locais e infecção } \\
\text { sistêmica. Atraso na manifestação de sintomas. }\end{array}$ \\
\hline Sorgo & $\begin{array}{l}\text { Colletotrichum } \\
\text { sublineolum (campo) }\end{array}$ & $\begin{array}{l}\text { Redução no número de lesões e na severidade da } \\
\text { doença, quando da aplicação da levedura antes } \\
\text { ou após o patógeno. Produção de grãos } \\
\text { equivalente ao do sorgo tratado com fungicida. }\end{array}$ \\
\hline Sorgo & $\begin{array}{l}\text { Exserohilum turcicum } \\
\text { (campo) }\end{array}$ & $\begin{array}{l}\text { Atraso na manifestação dos sintomas, redução na } \\
\text { severidade da doença e produção de grãos } \\
\text { equivalente ao do sorgo tratado com fungicida. }\end{array}$ \\
\hline
\end{tabular}




\section{MATERIAL E MÉTODOS}

\subsection{Saccharomyces cerevisiae - preparação elicitora bruta}

Levedura de panificação (S. cerevisiae), produto comercial Fermento Biológico Fresco Fleischmann ${ }^{\circledR}$, foi utilizada como fonte de células. Utilizou-se o procedimento descrito por Roveratti (1998), onde 200 gramas de células foram dissolvidas em 1 litro de água destilada. Tabletes utilizados na obtenção da preparação foram provenientes todos de um mesmo lote. A preparação resultante foi submetida a diferentes tempos de autoclavagem, objetivando uma maior extração do elicitor (solubilização das moléculas elicitoras), para isto realizou-se uma curva de autoclavagem conforme descrito no item 3.2.

\subsection{Curva de autoclavagem}

A preparação de levedura obtida conforme descrito no item 3.1 foi submetida a autoclavagem a $121^{\circ} \mathrm{C}$ a $1 \mathrm{~atm}$, sendo dividida em dois grupos de amostras. Um grupo de amostras foi autoclavado apenas uma única vez por 10, $20,30,40,50$ ou 60 minutos ou então por 1, 2, 3 ou 4 horas. Outro grupo de amostras foi obtido de uma suspensão de levedura preparada e autoclavada seqüencialmente nos tempos descritos anteriormente. Neste caso, cerca de 500 $\mathrm{mL}$ da suspensão de levedura foi preparada e aproximadamente $50 \mathrm{~mL}$ foram retirados e armazenados (preparação sem autoclavagem, denominado de tem- 
po 0). A seguir, a suspensão de $S$. cerevisiae foi levada a autoclavagem, no caso da autoclavagem em minutos, esta suspensão foi autoclavada por 10 minutos e após este período cerca de $50 \mathrm{~mL}$ foram retirados e armazenados. A suspensão foi novamente levada a autoclavagem por mais 20 minutos, e após este período cerca de $50 \mathrm{~mL}$ foram retirados e armazenados. Este procedimento foi repetido, submetendo a suspensão de levedura a mais 30,40 , 50 e 60 minutos de autoclavagem. Para a autoclavagem em horas, após a retirada da alíquota da suspensão não submetida a autoclavagem, a suspensão foi levada a autoclave por 1 hora e após este período cerca de $50 \mathrm{~mL}$ foram retirados e armazenados. A suspensão foi novamente levada a autoclave por mais 2, 3 e 4 horas, e ao final de cada período de tempo de autoclavagem, foram coletados e armazenados aproximadamente $50 \mathrm{~mL}$ da preparação.

Após a autoclavagem, as amostras foram centrifugadas a 15.000 $g$ por 30 minutos a $4{ }^{\circ} \mathrm{C}$. Os precipitados foram descartados e na preparação resultante (preparação elicitora bruta), dosados proteínas pelo método de Bradford (1976) e carboidratos pelo método de fenol sulfúrico (Dubois, 1956). As preparações foram congeladas e utilizadas nos bioensaios de fitoalexinas em mesocótilos de sorgo (item 3.6) e germinação de esporos e formação de apressórios por $C$. sublineolum e $C$. lagenarium (item 3.8). Os bioensaios foram realizados com as preparações com concentrações originais de carboidratos e com concentrações ajustadas, com base nos carboidratos presentes (mg carboidratos $/ 0,1 \mathrm{~g}$ de levedura), de modo que todos as preparações de um mesmo experimento tivessem a mesma concentração final de carboidratos. Bioensaios em mesocótilos de sorgo também foram realizados com a preparação não autoclavada (0 min), com as preparações autoclavadas por 30 e 60 min e com as preparações autoclavadas por 2 e 4 horas uma única vez ou seqüencialmente, com concentração ajustada de carboidratos e novamente diluídas 10, 100, 1.000 e 10.000 vezes. 


\subsection{Curva dose resposta}

Em função dos resultados de fitoalexinas em mesocótilos de sorgo e da concentração de proteínas e carboidratos analisados, a preparação de levedura autoclavada por 4 horas seqüencialmente foi escolhida para a continuação do processo de purificação. O efeito de doses (em $\mathrm{mg}$ carboidratos $/ 0,1 \mathrm{~g}$ de levedura) desta preparação na produção de fitoalexinas em mesocótilos de sorgo (item 3.6) e na germinação de esporos e formação de apressórios por C. sublineolum e C. lagenarium (item 3.8) foi avaliada. Para o bioensaio de fitoalexinas em mesocótilos de sorgo, partindo de uma preparação bruta com concentração inicial de carboidratos conhecida, foram preparadas diluições nas seguintes proporções: 1:20; 1:10: 1:8: 1:6; 1:4; 1:2 e 1. Para germinação de esporos e formação de apressórios dos fitopatógenos as concentrações avaliadas foram: 1:10: 1:8: 1:6; 1:4; 1:2 e 1 da preparação bruta.

\subsection{Curva de incubação}

A produção de fitoalexinas em mesocótilos de sorgo (item 3.6), tratados com a preparação autoclavada por 4 horas seqüencialmente, com $C$. sublineolum e com água destilada esterilizada, em diferentes tempos de incubação também foi avaliada.

\subsection{Separação dos componentes da preparação elicitora bruta através de cromatografia de troca iônica (CTI)}

A cromatografia de troca iônica foi realizada utilizando-se tampão Tris-HCl ou tampão bicarbonato de amônio para eluição do material do interior da coluna. Tampão bicarbonato de amônio foi utilizado objetivando evitar a 
perda de amostra e conseqüentemente do elicitor, durante a etapa de diálise, necessária quando o material adsorvido a coluna é retirado pela aplicação de $\mathrm{NaCl}$.

Para isto, aproximadamente 2 litros da preparação elicitora bruta foi preparada e autoclavada por 4 horas seqüencialmente, liofilizada e armazenada para a realização das CTIs. As amostras aplicadas foram ressuspensas no mesmo tampão de equilíbrio da coluna. A liofilização da preparação elicitora foi realizada com o objetivo de se concentrar a amostra a ser aplicada, a fim de obter uma maior concentração do (s) elicitor (es) presentes nas frações parcialmente purificadas.

Para a aplicação na coluna, a preparação bruta e todos os outros materiais aplicados foram previamente filtrados em membrana tipo Millipore $(0,45 \mu \mathrm{m})$ e desgaseificados por $10 \mathrm{~min}$. A coluna foi regenerada após cada aplicação de amostra (Apêndice 1).

\subsubsection{Cromatografia de troca iônica utilizando tampão Tris-HCl}

A cromatografia de troca iônica foi realizada em coluna de vidro $(2,5 \times 10 \mathrm{~cm})$ preenchida com Dietilaminoetil-Celulose (DEAE Celulose-Sigma), equilibrada com tampão Tris- $\mathrm{HCl} 10 \mathrm{mM}, \mathrm{pH}$ 8,0. Uma amostra de $5 \mathrm{~mL}$ da preparação bruta (com concentração de carboidratos e de proteínas de 71,66 $\mathrm{mg} / \mathrm{mL}$ e 16,96 mg/mL, respectivamente, após diálise em tampão de equilíbrio) foi aplicada ao leito da coluna de DEAE-Celulose e eluída com o tampão de equilíbrio, a fluxo de $2,5 \mathrm{~mL} / \mathrm{min}$. Após a saída do material não adsorvido, o material adsorvido foi deslocado pelo uso de soluções de $\mathrm{NaCl}$, no tampão de equilíbrio, nas seguintes concentrações: $0,12 \mathrm{M}, 0,21 \mathrm{M}, 0,50 \mathrm{M}$ e $1 \mathrm{M}$. Foram coletadas frações de $6 \mathrm{~mL}$.

Nas frações coletadas a presença de proteínas foi detectada espectrofotometricamente a $280 \mathrm{~nm}$. As frações, reunidas de acordo com o perfil de distribuição de proteínas, foram dialisadas contra água destilada (5 
litros) a $4{ }^{\circ} \mathrm{C}$, com 6 horas de intervalo entre as trocas de água (5 repetições). As frações dialisadas, em membrana com corte para 12-14 kDa, foram concentradas pelo uso de polietilenoglicol 20.000 e o volume final foi ajustado para $15 \mathrm{~mL}$. O conteúdo de carboidratos e de proteínas foi novamente determinado para as frações obtidas, utilizando os métodos já citados. Alíquotas das frações obtidas, com dose de proteínas ajustada para a menor concentração determinada, foram avaliadas quanto à capacidade elicitora de fitoalexinas em mesocótilos de sorgo (item 3.6), na germinação de esporos e formação de apressórios por $C$. lagenarium e $C$. sublineolum (item 3.8) e quanto à capacidade de proteção de plântulas de pepino a C. lagenarium (item 3.9) e proteção de plantas de sorgo a C. sublineolum (item 3.11).

\subsubsection{Cromatografia de troca iônica utilizando tampão bicarbonato de amônio}

A CTI foi realizada em coluna de vidro $(2,5 \times 10 \mathrm{~cm})$ preenchida com Dietilaminoetil-Celulose (DEAE Celulose-Sigma), equilibrada com tampão bicarbonato de amônio $10 \mathrm{mM}, \mathrm{pH} \mathrm{8,0}$. Uma amostra de $5 \mathrm{~mL}$ da preparação bruta ressuspensa no mesmo tampão de equilíbrio da coluna (com concentração de carboidratos e de proteínas de $434,18 \mathrm{mg} / \mathrm{mL}$ e $11,87 \mathrm{mg} / \mathrm{mL}$, respectivamente), foi aplicada no leito da coluna de DEAE-Celulose e eluída

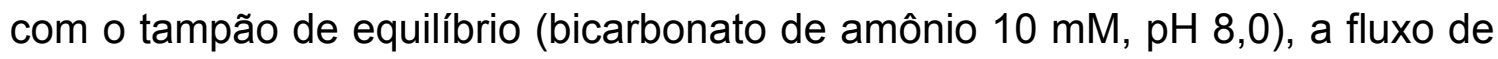
$2,5 \mathrm{~mL} / \mathrm{min}$. Após a saída do material não adsorvido, o material adsorvido foi deslocado pelo aumento de concentração do tampão bicarbonato de amônio como segue: $0,125 \mathrm{M}, 0,25 \mathrm{M}, 0,50 \mathrm{M}$ e $1 \mathrm{M}$. Frações de $6 \mathrm{~mL}$ foram coletadas.

Nas frações coletadas a presença de proteínas foi detectada espectrofotometricamente a $280 \mathrm{~nm}$. As frações, reunidas de acordo com o perfil de distribuição de proteínas foram liofilizadas e ressuspensas em $10 \mathrm{~mL}$ de água destilada. O conteúdo de carboidratos e de proteínas foi novamente determinado para as frações obtidas, utilizando os métodos já citados. 
Alíquotas das frações obtidas, com dose de proteínas ajustada para a menor concentração determinada, foram avaliadas quanto à capacidade elicitora de fitoalexinas em mesocótilos de sorgo (item 3.6), na germinação de esporos e formação de apressórios por $C$. lagenarium e $C$. sublineolum (item 3.8) e quanto à capacidade de proteção de plântulas de pepino a C. lagenarium (item 3.9) e proteção de plantas de sorgo a C. sublineolum (item 3.11).

\subsection{Bioensaio para produção de fitoalexinas em mesocótilos de sorgo}

Para o bioensaio de fitoalexinas, sementes de sorgo [Sorghum bicolor (L.) Moench], cultivar BRS-501, foram desinfectadas em hipoclorito de sódio 1\% (15 min), lavadas em água destilada e embebidas em água, sob temperatura ambiente por 12 horas. Após este período foram enroladas em folhas de papel de germinação umedecidas e incubadas no escuro a $28 \pm 2{ }^{\circ} \mathrm{C}$ por 4 dias. As plântulas formadas foram expostas à luz por 4 horas para paralisar a elongação dos mesocótilos (Nicholson et al., 1988; Yamaoka et al., 1990). Desta maneira, foram obtidas plântulas com mesocótilos uniformemente elongados e adequados para o bioensaio de produção de fitoalexinas (Wulff, 1997).

No teste de produção de fitoalexinas, mesocótilos previamente tratados ou não com o abrasivo carborundum (item 3.6.1), receberam por aspersão $2 \mathrm{~mL}$ das preparações de levedura autoclavadas em diferentes tempos ou as frações obtidas pelas cromatografias de coluna. Água destilada esterilizada foi utilizada como controle negativo, enquanto que acibenzolar-Smetil (ASM) (50 ppm) mais o abrasivo carborundum e $C$. sublineolum foram utilizados como controles positivos. Em alguns bioensaios foi adicionado antibiótico (item 3.6.2) em função da alta concentração de carboidratos nas preparações de levedura, nestes casos água com e sem antibiótico foram utilizados como controles negativos. Os mesocótilos foram mantidos em câmara 
úmida, a $25 \pm 2{ }^{\circ} \mathrm{C}$ sob luz fluorescente por um período de 65 horas (Wulff, 1997). Após esse período, 3 mesocótilos por repetição (5 repetições por tratamento), foram cortados e uma porção de $2,5 \mathrm{~cm}$ pesada, cortada em pequenos segmentos e colocados em tubos para microcentrífuga contendo 1,4 $\mathrm{mL}$ de metanol $80 \%$ acidificado $(0,1 \% \mathrm{HCl}$; v/v). Os segmentos de mesocótilos foram mantidos a $4{ }^{\circ} \mathrm{C}$ no metanol por 96 horas para extração dos pigmentos e a absorbância foi determinada a $480 \mathrm{~nm}$ (Nicholson et al., 1987, 1988). Os dados foram expressos em absorbância a $480 \mathrm{~nm}$ por grama de tecido fresco (Abs (480 nm)/g.t.f.). As etapas do bioensaio de produção de fitoalexinas em mesocótilos de sorgo são representadas na Figura 1.

\subsubsection{Obtenção de controles positivos eficientes para o bioensaio de produção de fitoalexinas em mesocótilos de sorgo}

Em função da adaptação do bioensaio realizado por Wulff (1997), que resultou numa ineficiência dos controles positivos, fez-se necessário à busca por tratamentos controles positivos eficientes. Para isto, mesocótilos de sorgo estiolados receberam através de aspersão $2 \mathrm{~mL}$ das seguintes substâncias: ASM (50 ppm), ASM (50 ppm) com tratamento prévio dos mesocótilos estiolados com abrasivo carborundum $(A S M+C)$, através do auxílio de um cotonete; água destilada esterilizada e suspensão de esporos de $C$. sublineolum ( $1 \times 10^{5}$ esporos $\left./ \mathrm{mL}\right)$ autoclavada ou não autoclavada. 

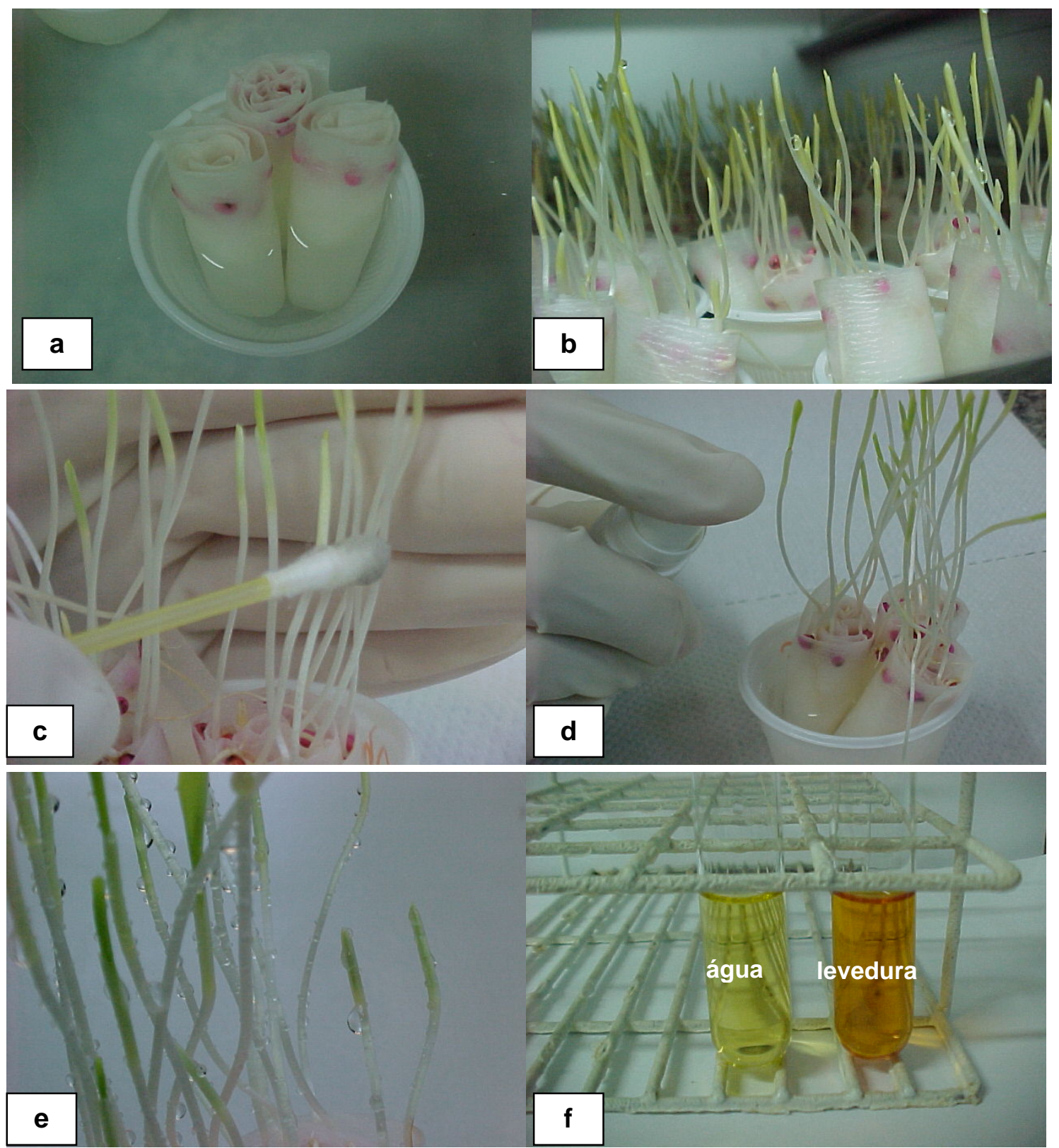

Figura 1 - Bioensaio para produção de fitoalexinas em mesocótilos de sorgo; (a). Sementes de sorgo colocadas para germinar; (b). Mesocótilos de sorgo estiolando após 3 dias de incubação; (c). Tratamento prévio com abrasivo carborundum; (d). Aspersão do preparado elicitor; (e). Mesocótilos aspergidos com água; (f). Amostra das fitoalexinas extraídas em metanol, mesocótilos tratados com água ou com preparação de Saccharomyces cerevisiae autoclavada 60 minutos seqüencialmente 


\subsubsection{Efeito de antibiótico na produção de fitoalexinas em mesocótilos de sorgo}

Em função das altas concentrações de carboidratos presentes nas preparações de levedura, obtidas nos diferentes tempos de autoclavagem, foi necessário à adição de antibiótico nas amostras a serem testadas com o objetivo de se evitar a contaminação por bactérias. Para avaliar o efeito do antibiótico na síntese de fitoalexinas um bioensaio prévio foi realizado utilizando água destilada esterilizada com e sem antibiótico. Foi utilizado o antibiótico Pentabiótico $®$ Veterinário Reforçado (Fort Dodge) na concentração de 0,08 $\mathrm{mg} / \mathrm{mL}$, que contém na sua fórmula benzilpenicilina benzatina, benzilpenicilina procaína, benzilpenicilina potássica, diidroestreptomicina e estreptomicina.

\subsection{Obtenção, manutenção e preparo das suspensões de esporos dos fitopatógenos}

\subsubsection{Obtenção e manutenção dos fitopatógenos}

Colletotrichum lagenarium (Pass.) Ellis \& Halted - o fungo foi isolado a partir de lesões em folhas de pepino e mantido em meio aveia-ágar, sob luz U.V., comprimento de onda longo (NUV) à temperatura de $20 \pm 2^{\circ} \mathrm{C}$.

Colletotrichum sublineolum Henn. (sinonímia C. graminicola Ces. Wils.) - o isolado foi obtido a partir de lesões em folhas de sorgo e mantido em meio aveia-ágar, sob luz U.V., comprimento de onda longo (NUV) à temperatura de $20 \pm 2{ }^{\circ} \mathrm{C}$. 


\subsubsection{Preparo das suspensões de esporos dos fitopatógenos}

Para a obtenção dos conídios foram utilizadas colônias produzidas conforme descrito no item 3.7.1, com até 15 dias de idade, que tiveram água destilada esterilizada adicionada a sua superfície. As suspensões obtidas foram filtradas em gaze e as concentrações ajustadas numa faixa de $1 \times 10^{5}$ até $2,5 \mathrm{x}$ $10^{5}$ esporos $/ \mathrm{mL}$ (com o auxílio de hematocitômetro) e utilizadas nos bioensaios de germinação de esporos e formação de apressórios (item 3.8), para inoculação de mesocótilos estiolados em sorgo (C. sublineolum) (item 3.6), para inoculação de plântulas de pepino (C. lagenarium) (item 3.9) ou para a inoculação de plantas de sorgo (C. sublineolum) (item 3.11).

3.8 Efeito das preparações brutas e das frações parcialmente purificadas por CTI na germinação de esporos e formação de apressórios por fitopatógenos

$\mathrm{Na}$ avaliação microscópica da germinação de esporos e formação de apressórios dos fitopatógenos foram testadas as preparações de $S$. cerevisiae obtidas em diferentes tempos de autoclavagem (minutos ou horas), o efeito de concentrações da preparação de $S$. cerevisiae autoclavada por 4 horas seqüencialmente e o efeito das frações parcialmente purificadas por CTI.

\subsubsection{Bioensaio de germinação de esporos e formação de apressórios por Colletotrichum lagenarium e Colletotrichum sublineolum}

Para o teste de avaliação da germinação de esporos e formação de apressórios por $C$. lagenarium ou $C$. sublineolum utilizou-se placas de teste Elisa. Portanto, uma alíquota de $40 \mu \mathrm{l}$ da suspensão de esporos e outra alíquota de $40 \mu \mathrm{l}$ dos tratamentos foram colocadas em cada um dos recipientes 
("pocinhos") de uma placa usada em teste de ELISA (Regente et al., 1997). Como controle utilizou-se água destilada esterilizada sem ou, quando necessário, com antibiótico (Pentabiótico® Veterinário Reforçado (Fort Dodge), na concentração de $0,08 \mathrm{mg} / \mathrm{mL}$ ). Após, as placas foram incubadas sob luz constante a $25 \pm 2{ }^{\circ} \mathrm{C}$. A porcentagem de germinação de esporos e formação de apressórios foi determinada 24 horas após o início do experimento, através do emprego de $20 \mu \mathrm{L}$ do corante azul algodão de lactofenol, utilizado para paralisar a germinação. A avaliação foi realizada através da observação ao microscópio ótico com aumento de 400 vezes. Contou-se 100 esporos por repetição, totalizando 800 esporos por tratamento. Foram considerados como esporos germinados aqueles que apresentaram qualquer indício de emissão do tubo germinativo.

\subsection{Proteção de plântulas de pepino a Colletotrichum lagenarium, em câmara de crescimento e casa-de-vegetação, utilizando as frações obtidas nas CTIs}

\subsubsection{Proteção de plântulas de pepino em câmara de crescimento}

Sementes de pepino (Cucumis sativus L.) da cultivar Caipira foram plantadas em bandejas contendo substrato agrícola Plantmax® (Eucatex) e mantidas em casa-de-vegetação sob condição ambiental. Cinco ou seis dias após a semeadura as plântulas foram retiradas das bandejas e suas raízes lavadas duas vezes com água. A seguir as plântulas foram tratadas com as frações obtidas nas CTls ou com as preparações dos tratamentos controles e transferidas para tubos de ensaio contendo água destilada e mantidas em câmara de crescimento sob regime de $12 \mathrm{~h}$ luz (lâmpadas fluorescentes) e $12 \mathrm{~h}$ escuro a $26 \pm 2{ }^{\circ} \mathrm{C}$, até o final do experimento. Após três dias do tratamento elicitor, as plântulas foram inoculadas por aspersão com suspensão de conídios 
de C. lagenarium, e mantidas em câmara úmida por 24 h. Os ensaios foram conduzidos com 3 repetições e cada repetição foi composta por 4 tubos de ensaios, mantidos em uma mesma linha do suporte de tubos, cada qual com 1 plântula.

No tratamento elicitor, a concentração das frações obtidas na CTI foram ajustadas, com base nas proteínas presentes (equivalentes de albumina de soro bovino $/ \mathrm{mL}$ ), de modo que todas as frações de um mesmo experimento tivessem a mesma concentração de proteínas. As plântulas de pepino foram tratadas, uma a uma, pela imersão (aproximadamente $5 \mathrm{~s}$ ) dos cotilédones nas frações. Água destilada esterilizada foi utilizada como controle negativo e ASM (50 ppm) utilizado como padrão de indução de resistência. A preparação de $S$. cerevisiae autoclavada seqüencialmente por 4 horas (extrato bruto), com concentração original de proteínas, também foi testada na proteção de plântulas de pepino.

A avaliação dos sintomas foi realizada de 5 a 8 dias após a inoculação, em função do surgimento das lesões no tratamento controle negativo (água), sendo a severidade de antracnose determinada visualmente.

\subsubsection{Proteção de plântulas de pepino em casa-de-vegetação}

Sementes de pepino foram plantadas em bandejas contendo substrato agrícola Plantmax® (Eucatex) e mantidas em casa-de-vegetação sob condições ambientais. Cinco dias após a semeadura as plântulas receberam através de pincelamento as frações obtidas nas CTls e as preparações dos tratamentos controles e mantidas em casa-de-vegetação nas mesmas condições de cultivo. Após três dias do tratamento elicitor, as plântulas foram inoculadas por aspersão com suspensão de conídios de C. lagenarium, e mantidas em câmara úmida por $24 \mathrm{~h}$. Os ensaios foram conduzidos com 3 repetições e cada repetição foi composta por 4 plântulas de pepino. 
No tratamento elicitor, a concentração das frações obtidas nas CTIs foram ajustadas, com base nas proteínas presentes (equivalentes de albumina de soro bovino/mL), de modo que todas as frações de um mesmo experimento tivessem a mesma concentração de proteínas. As plântulas de pepino foram tratadas, uma a uma, quando os cotilédones receberam através de pincelamento as frações. Água destilada esterilizada foi utilizada como controle negativo e ASM (50 ppm) utilizado como padrão de indução de resistência. A preparação de $S$. cerevisiae autoclavada seqüencialmente por 4 horas (extrato bruto), com concentração original de proteínas, também foi testada na proteção de plântulas de pepino.

A avaliação dos sintomas foi realizada de 5 a 6 dias após a inoculação, variando em função do surgimento das lesões no tratamento controle (água), sendo a severidade de antracnose determinada visualmente.

O bioensaio de proteção de plântulas de pepino é apresentado na Figura 2.

\subsection{Análise bioquímica}

Em conjunto aos tratamentos descritos no item 3.9.2 foram coletadas amostras do tecido vegetal para a dosagem da atividade de peroxidases imediatamente antes do tratamento elicitor (T0), imediatamente antes da inoculação e três dias após o tratamento elicitor (T3); e 3 dias após a inoculação, ou seja, seis dias após o tratamento elicitor (T6). 

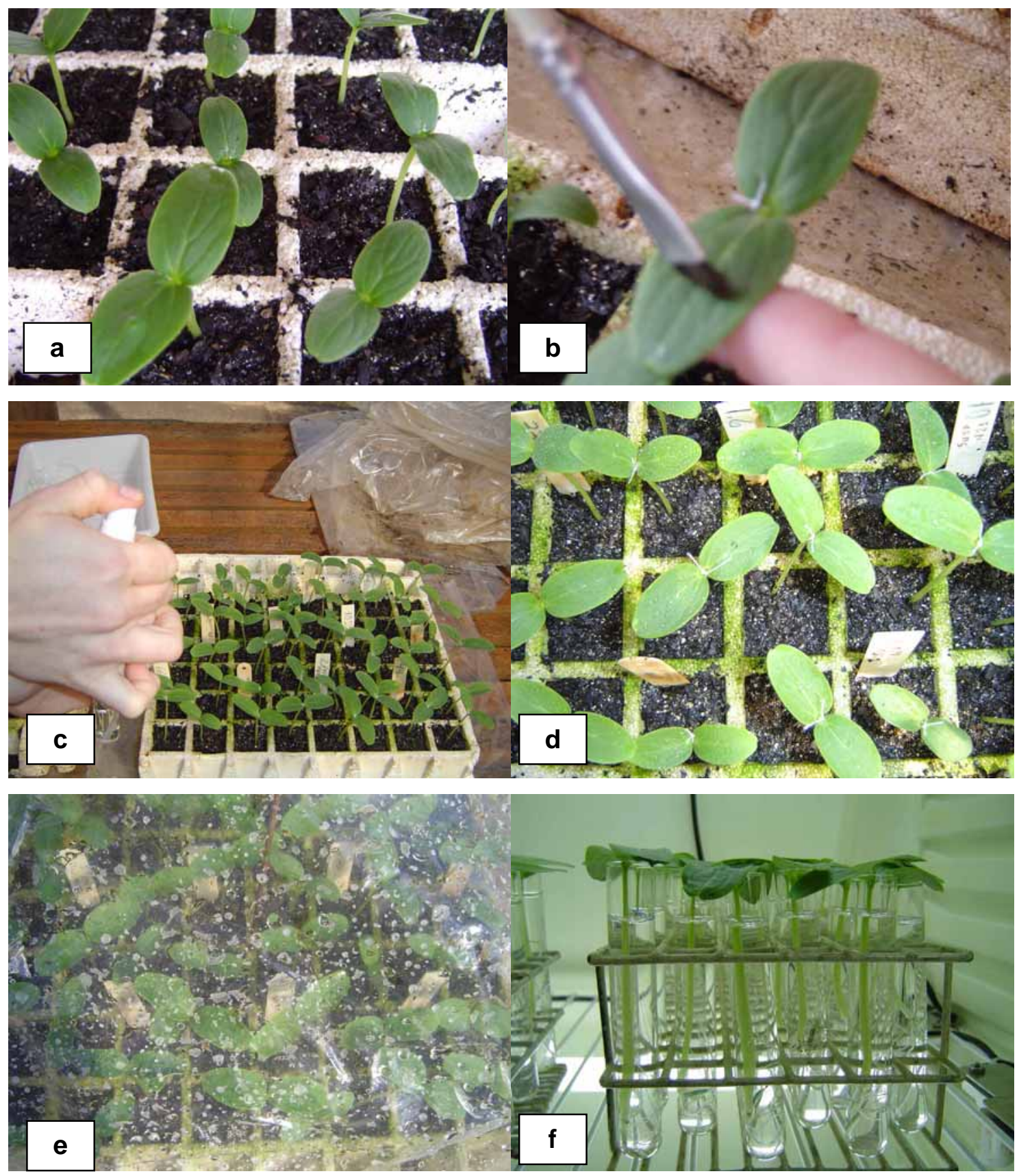

Figura 2 - Bioensaio para a proteção de plântulas de pepino; (a). Cotilédones de plântulas de pepino em casa-de-vegetação, com 5 dias de idade; (b). Aplicação do elicitor por pincelamento; (c). Inoculação do patógeno por aspersão; (d). Cotilédones inoculados; (e). Câmara úmida após a inoculação do patógeno; (f). Cotilédones de pepino em tubos de ensaio, mantidos em câmara de crescimento 


\subsubsection{Atividade de peroxidases}

Amostras de tecido vegetal constituídas de 2 cotilédones (aproximadamente $0,3 \mathrm{~g}$ de peso fresco) foram homogeneizadas em 4,0 $\mathrm{mL}$ de tampão acetato de sódio $100 \mathrm{mM}$ (pH 5,0) (tampão de extração) e submetidas a centrifugação a $20.000 \mathrm{~g}\left(25 \mathrm{~min}, 4{ }^{\circ} \mathrm{C}\right)$. Os sobrenadantes foram utilizados para se avaliar a atividade enzimática e também o teor de proteínas (Bradford, 1976).

A atividade de peroxidases foi determinada a $30{ }^{\circ} \mathrm{C}$ através de método espectrofotométrico direto, pela medida da conversão do guaiacol em tetraguaiacol a $470 \mathrm{~nm}$ (Roncatto \& Pascholati, 1998). Em uma cubeta de vidro, com capacidade de $3 \mathrm{~mL}$, foram adicionados 2,9 mL de tampão de reação (250 $\mu \mathrm{L}$ de guaiacol e $306 \mu \mathrm{L}$ de peróxido de hidrogênio em $100 \mathrm{~mL}$ de tampão fosfato $0,01 \mathrm{M}(\mathrm{pH} 6,0))$ a $0,1 \mathrm{~mL}$ do extrato protéico (sobrenadante). A cubeta de referência continha $3 \mathrm{~mL}$ da solução com $250 \mu \mathrm{L}$ de guaiacol e $306 \mu \mathrm{L}$ de peróxido de hidrogênio em $100 \mathrm{~mL}$ de tampão fosfato $0,01 \mathrm{M}(\mathrm{pH} \mathrm{6,0)}$. A atividade específica da enzima foi expressa em $\Delta$ abs $470 \mathrm{~nm} / \mathrm{min} / \mathrm{mg}$ proteína.

\subsection{Proteção de plantas de sorgo a Colletotrichum sublineolum em casa- de-vegetação utilizando as frações obtidas nas CTIs}

Para a avaliação da indução de resistência em sorgo, plantas da cultivar BRS-501 foram cultivadas em vasos contendo uma mistura de solo, areia e matéria orgânica autoclavados. As plantas (3 plantas por vaso, sendo que cada planta representou uma repetição) foram mantidas em casa-devegetação sob condições ambientais. Foram realizados dois experimentos, sendo que no primeiro experimento as plantas receberam aos 17 dias de idade o tratamento elicitor, e no segundo experimento o tratamento elicitor foi realizado em plantas com 47 dias de idade. Após 3 dias do tratamento elicitor 
foi realizada a inoculação com suspensão de esporos de $C$. sublineolum (1 ou $1,25 \times 10^{5}$ conídios $/ \mathrm{mL}$ ) e as plantas foram mantidas em câmara úmida por 24 horas. Após este período as plantas foram removidas da câmara úmida e mantidas em casa-de-vegetação.

No tratamento elicitor, a concentração das frações obtidas nas CTIs foram ajustadas, com base nas proteínas presentes (equivalentes de albumina de soro bovino $/ \mathrm{mL}$ ), de modo que todas as frações de um mesmo experimento tivessem a mesma concentração de proteínas. A quarta folha de cada planta de sorgo foi marcada e tratada com as frações através de pincelamento. Água destilada esterilizada foi utilizada como controle negativo e ASM (50 ppm) utilizado como padrão de indução de resistência. Preparação de S. cerevisiae autoclavada seqüencialmente por 4 horas, com concentração original de proteínas, também foi utilizada no tratamento das plantas de sorgo.

A avaliação dos sintomas foi realizada 7 dias após a inoculação com base nos parâmetros de severidade da doença nas folhas, para o qual foi utilizada uma escala conforme Piccinin (1995) (Figura 3), que visa avaliar apenas parte das folhas, o que explica, o formato retangular das ilustrações. Devido ao crescimento da folha ser da base para o ápice, adotou-se como local de medição uma distância de $10 \mathrm{~cm}$ a partir do ápice para base, avaliando-se somente $25 \mathrm{~cm}$ do comprimento da folha. Para facilitar o processo de avaliação construiu-se um quadro de papelão (Figura 4) (Piccinin, 1995), que foi utilizado juntamente com a escala diagramática.

Foram avaliados os sintomas na folha tratada (quarta folha) e na folha superior (quinta folha) do segundo experimento realizado. 


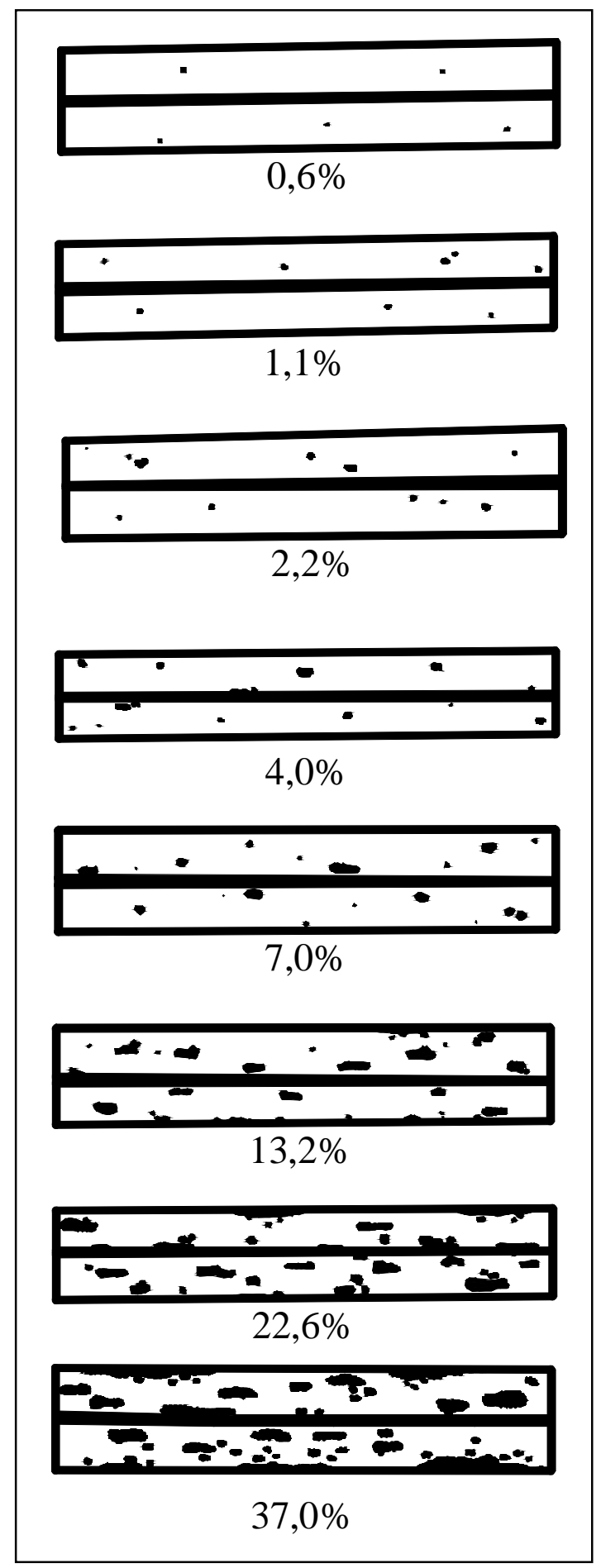

Figura 3 - Escala diagramática para a determinação da severidade da doença antracnose causada por Colletotrichum sublineolum em folhas de sorgo (Piccinin, 1995) 


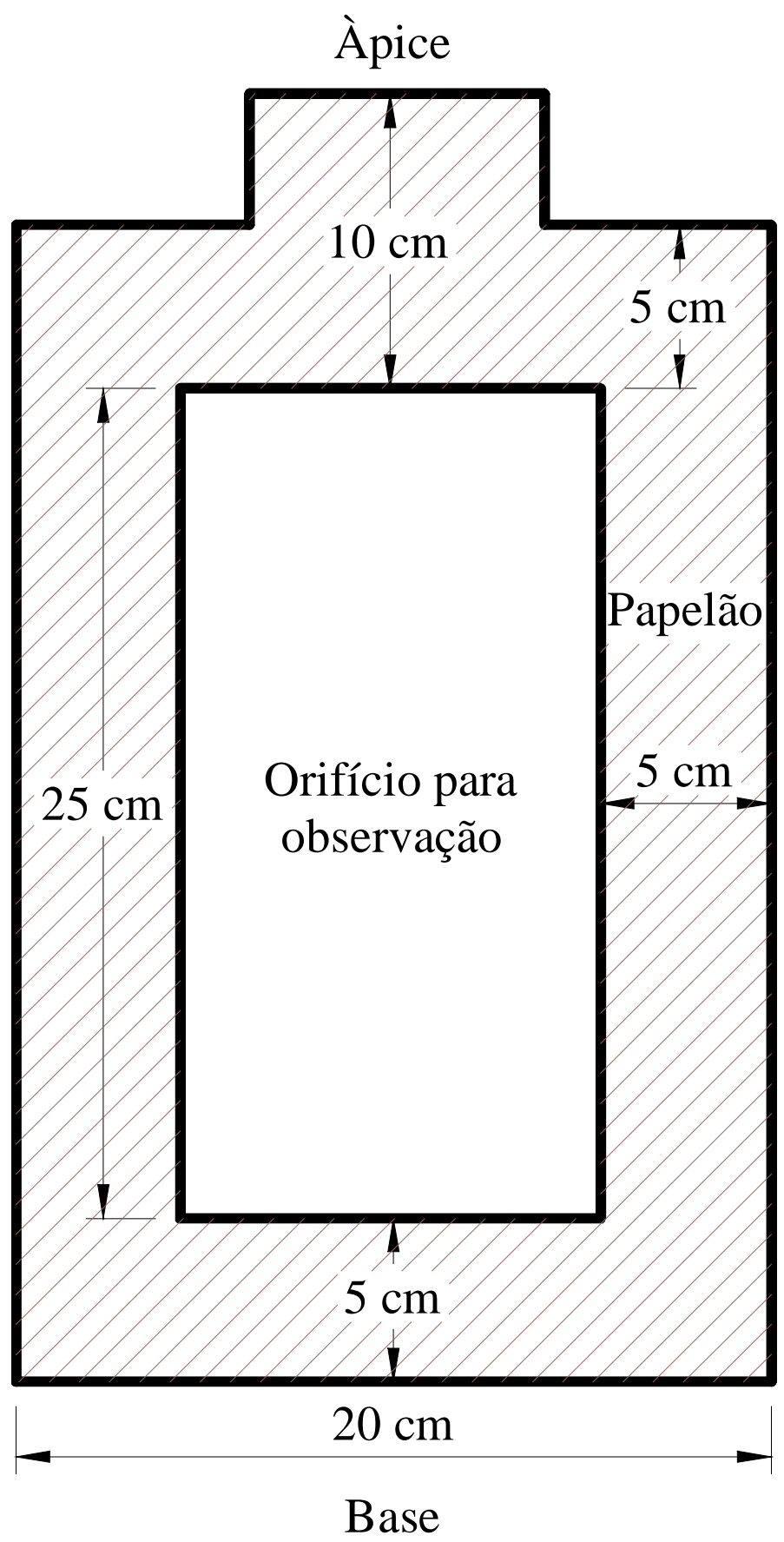

Figura 4 - Molde para avaliação da severidade de Colletotrichum sublineolum em folhas de sorgo (Piccinin, 1995) 


\subsection{Determinação da concentração de proteínas e carboidratos}

Para a quantificação dos teores de proteína das preparações e frações obtidas nas CTIs, foi utilizado o método de Bradford (1976), usando albumina de soro bovino (ASB) como padrão (Apêndice 2.a) ou determinação espectrofotométrica a $280 \mathrm{~nm}$. Os carboidratos foram quantificados pelo uso do método do fenol sulfúrico (Dubois, 1956), usando glicose como padrão (Apêndice 2.b).

$\mathrm{Na}$ determinação da curva padrão de carboidratos, soluções de glicose nas concentrações de $0,10,20,30,40$ e $50 \mu \mathrm{g} / 0,5 \mathrm{~mL}$ foram utilizadas. A curva padrão de proteínas foi determinada com soluções de ASB nas concentrações de 0, 2, 4, 6, 8 e $10 \mu \mathrm{g} / 0,8 \mathrm{~mL}$.

\subsection{Espectrofotometria de infravermelho}

A preparação de S. cerevisiae não autoclavada (tempo 0 min) e a preparação autoclavada por 4 horas seqüencialmente foram analisadas por Infravermelho (IR) na Embrapa-CNPDIA em São Carlos/SP, junto ao laboratório do Professor Luiz Alberto Colnago.

Para a obtenção do espectro na região do IR um miligrama de amostra foi homogeneizado com $100 \mathrm{mg}$ de $\mathrm{KBr}$ e prensado para a formação da pastilha. 


\section{RESULTADOS}

\subsection{Curva de autoclavagem para a extração do elicitor produzido por Saccharomyces cerevisiae}

A curva de autoclavagem foi realizada quatro vezes para autoclavagem em minutos e duas vezes para autoclavagem em horas, sendo escolhido um dos experimentos para ilustrar os resultados obtidos.

O processo de autoclavagem levou a obtenção de uma solução amarelada (Figura 5a), principalmente nas preparações autoclavadas seqüencialmente (Figura $5 \mathrm{~b}$ ). As preparações de $\mathrm{S}$. cerevisiae apresentaram coloração amarelada mais intensa quanto maior o tempo de autoclavagem.

Os resultados da influência do tempo de autoclavagem em minutos e horas na concentração de carboidratos das preparações de $S$. cerevisiae são apresentados na Figura 6. A concentração de carboidratos da preparação não autoclavada (tempo 0 ) é inferior a concentração de carboidratos das preparações autoclavadas. Preparações autoclavadas seqüencialmente apresentaram maior concentração de carboidratos do que as preparações autoclavadas apenas uma vez em minutos ou horas. As maiores concentrações de carboidratos foram observadas nas preparações autoclavadas por 3 e 4 horas seqüencialmente (Figura $6 b$ ).

A concentração de proteínas das preparações submetidas a autoclavagem é maior do que a concentração de proteínas da preparação não autoclavada, portanto, com a autoclavagem ocorre solubilização de proteínas 
nas amostras. Entretanto, não houve alteração significativa na concentração de proteínas quando as preparações foram autoclavadas uma vez ou seqüencialmente (Figura 7).

Analisando a concentração de proteínas e carboidratos das preparações submetidas a autoclavagem, em minutos ou horas, uma vez ou seqüencialmente, foi possível observar que em todas as preparações a concentração de carboidratos foi maior que a concentração de proteínas (Figura $8)$. 


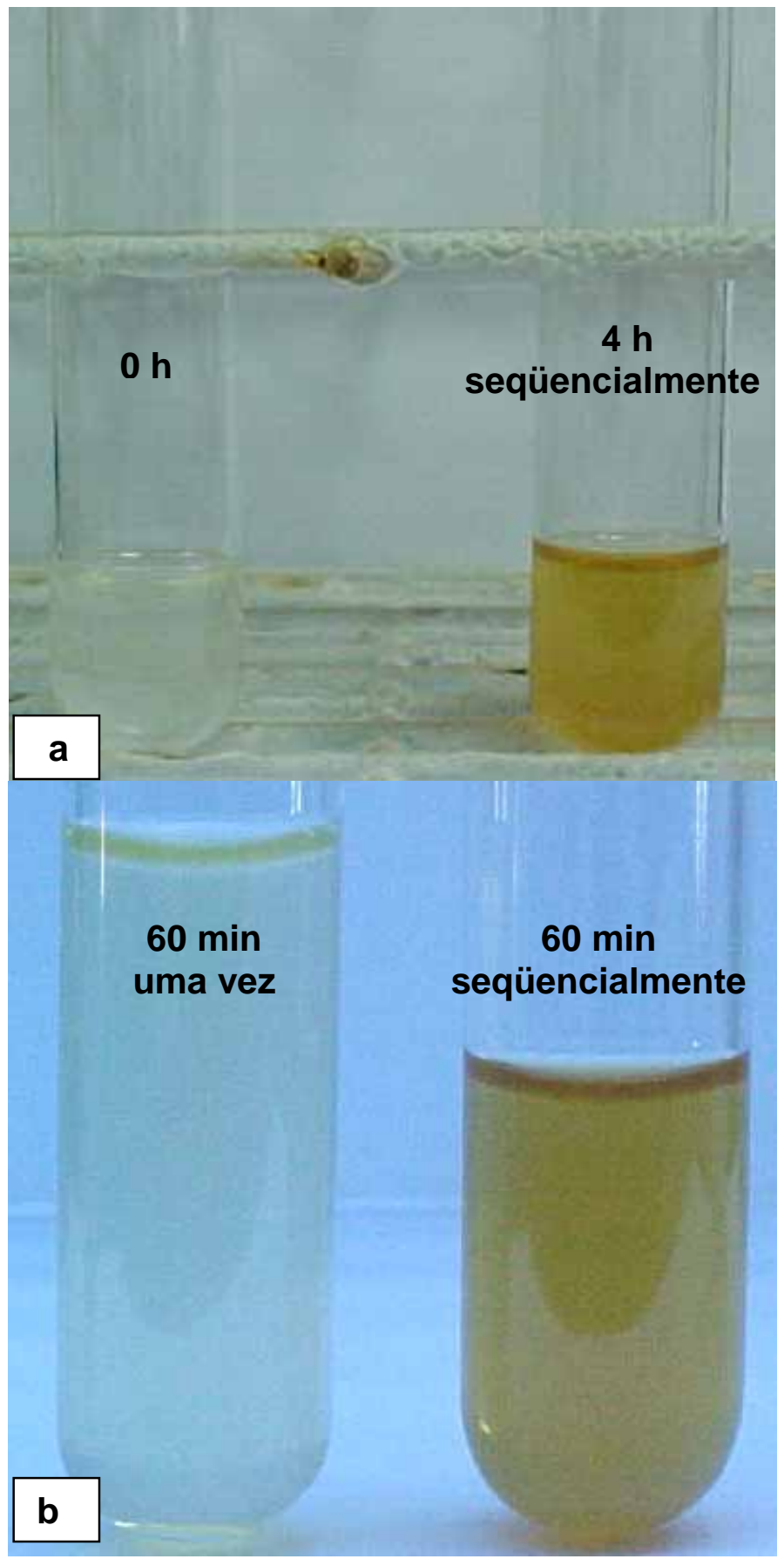

Figura 5 - (a). Preparação de Saccharomyces cerevisiae sem autoclavagem e levedura autoclavada por 4 horas seqüencialmente; (b). Preparações autoclavadas por 60 minutos uma vez ou por 60 minutos seqüencialmente 

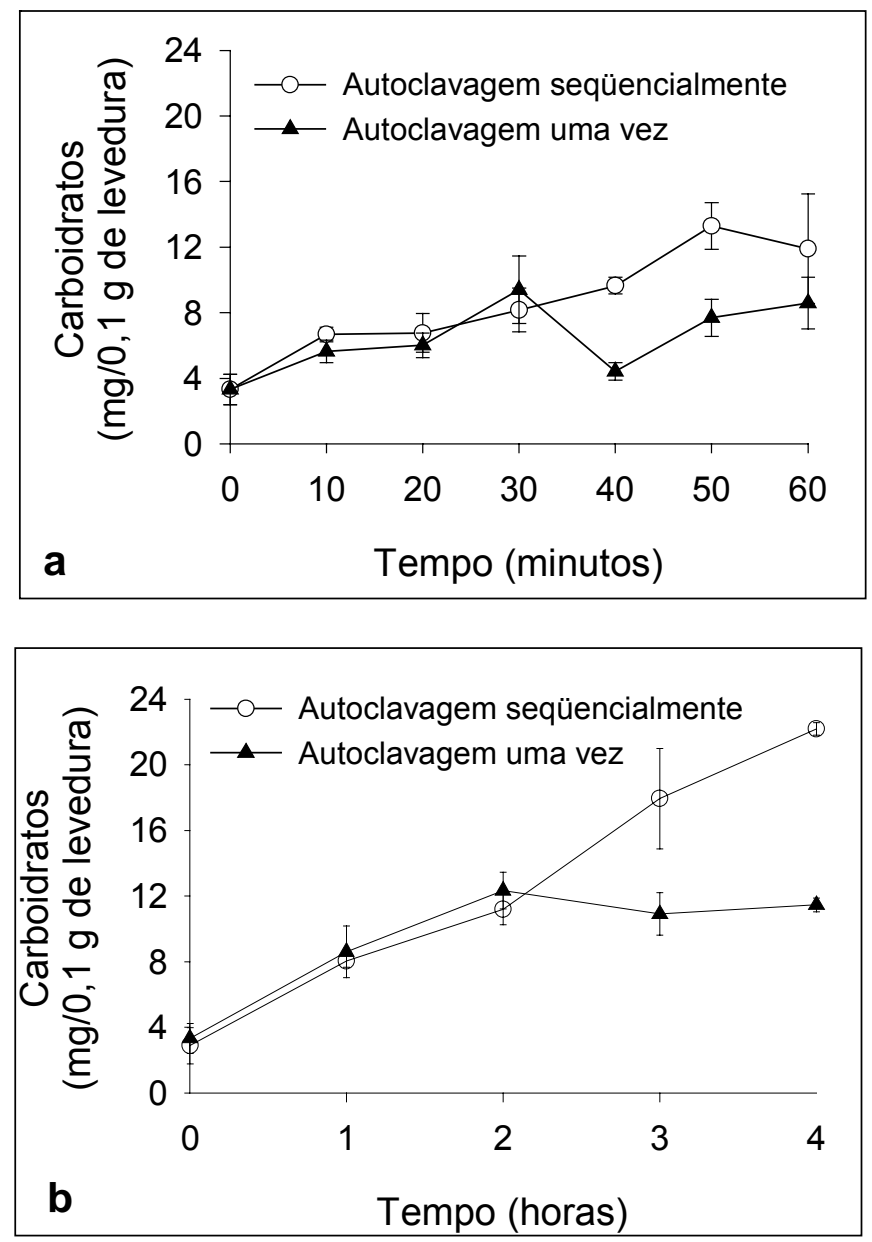

Figura 6 - Concentração de carboidratos das preparações de Saccharomyces cerevisiae autoclavadas; a). Autoclavagem em minutos; (b). Autoclavagem em horas. Tempo 0 corresponde a preparação não autoclavada 

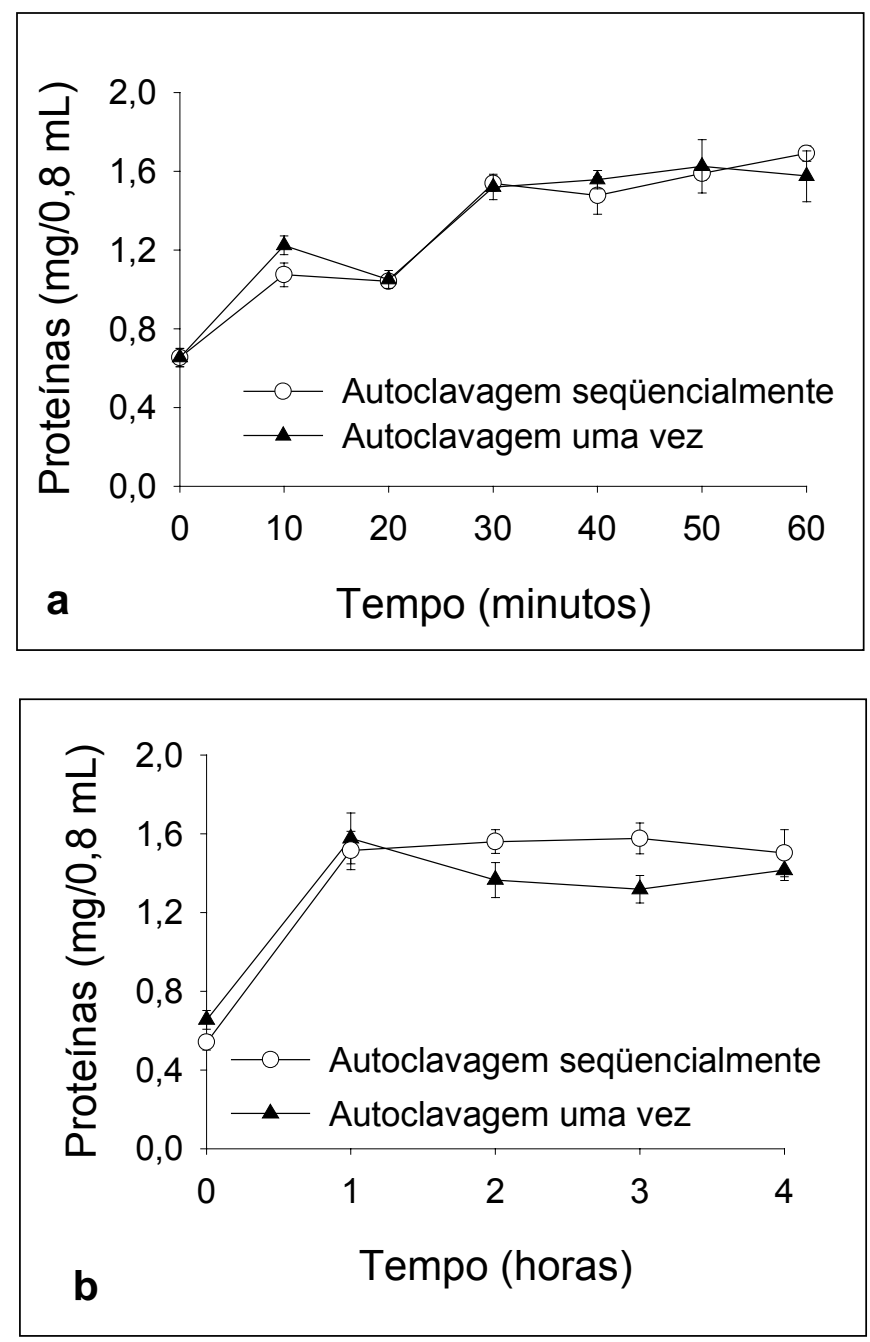

Figura 7 - Concentração de proteínas das preparações de Saccharomyces cerevisiae autoclavadas; (a). Autoclavagem em minutos; (b). Autoclavagem em horas. Tempo 0 corresponde a preparação não autoclavada 


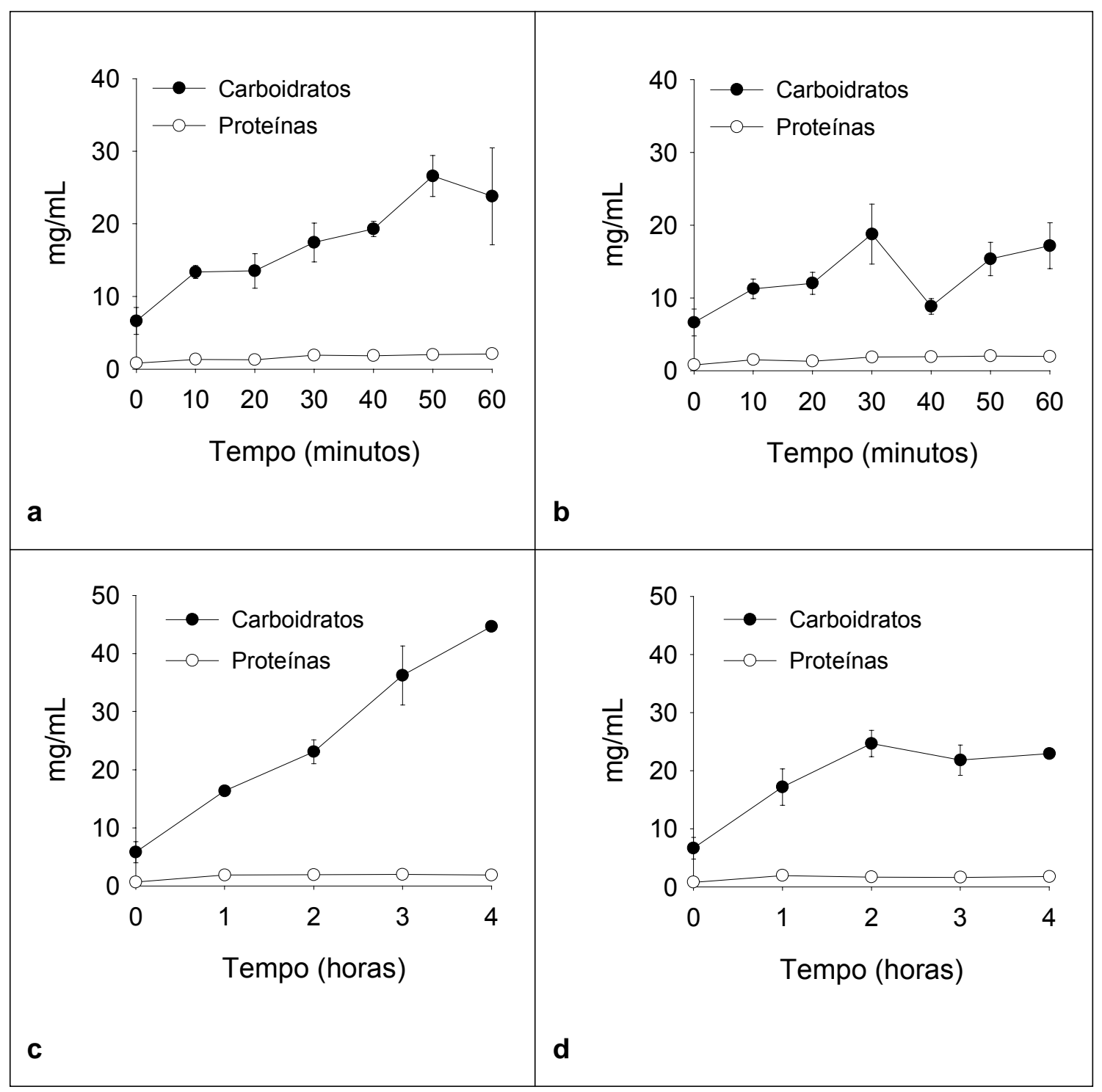

Figura 8 - (a) e (c). Comparação da concentração de proteínas e carboidratos nas preparações de Saccharomyces cerevisiae autoclavadas seqüencialmente; (b) e (d). Comparação da concentração de proteínas e carboidratos nas preparações de Saccharomyces cerevisiae autoclavadas uma vez 


\subsection{Produção de fitoalexinas em mesocótilos de sorgo}

\subsubsection{Obtenção dos controles positivos}

Em função da adaptação do bioensaio realizado por Wulff (1997) não foi possível observar a produção de fitoalexinas em mesocótilos de sorgo tratados com ASM, normalmente utilizado como padrão de indução de resistência. Assim, bioensaios foram realizados na tentativa de se padronizar alguns tratamentos para serem usados como controles positivos (Figura 9).

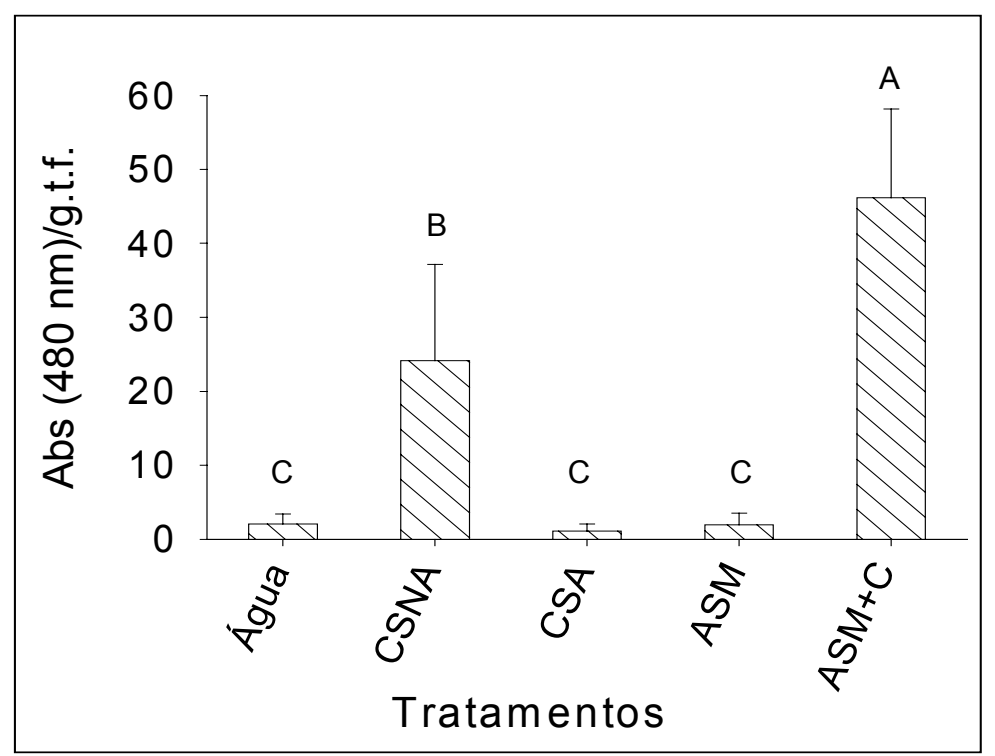

Figura 9 - Acúmulo de fitoalexinas em mesocótilos de sorgo após tratamento com água; CSNA (Colletotrichum sublineolum, 2,5 x 10 5 esporos $/ \mathrm{mL}$, não autoclavado); CSA (Colletotrichum sublineolum, $2,5 \times 10^{5}$ esporos $/ \mathrm{mL}$, autoclavado), ASM (acibenzolar-S-metil) e ASM+C (acibenzolar-S-metil com tratamento prévio usando abrasivo carborundum). Médias seguidas da mesma letra não são significativamente diferentes entre si (teste de Tukey $P=0,01$ ). As barras representam o desvio padrão da média de 5 repetições. $C V=$ $53,02 \%$ 
Observa-se que houve síntese de fitoalexinas quando os mesocótilos foram aspergidos com o patógeno $C$. sublineolum não autoclavado, e quando os mesocótilos foram previamente tratados com abrasivo carborundum e em seguida aspergidos com ASM. O patógeno autoclavado e o ASM não promoveram o acúmulo das fitoalexinas.

Portanto, nos bioensaios de produção de fitoalexinas com as preparações ou frações parcialmente purificadas obtidas de S. cerevisiae, os tratamentos $A S M+C$ e $C$. sublineolum foram utilizados como controles positivos.

\subsubsection{Efeito da adição de antibiótico na produção de fitoalexinas}

Em função da alta concentração de carboidratos presentes nas amostras, foi realizado um bioensaio prévio para verificar se a adição de antibiótico promovia alteração no acúmulo de fitoalexinas em mesocótilos de sorgo estiolados. Os resultados evidenciaram que não houve alteração no acúmulo de fitoalexinas com a adição de antibiótico (Figura 10), o que permitiu a realização dos bioensaios com as preparações de $S$. cerevisiae sem a presença de bactérias contaminantes. 


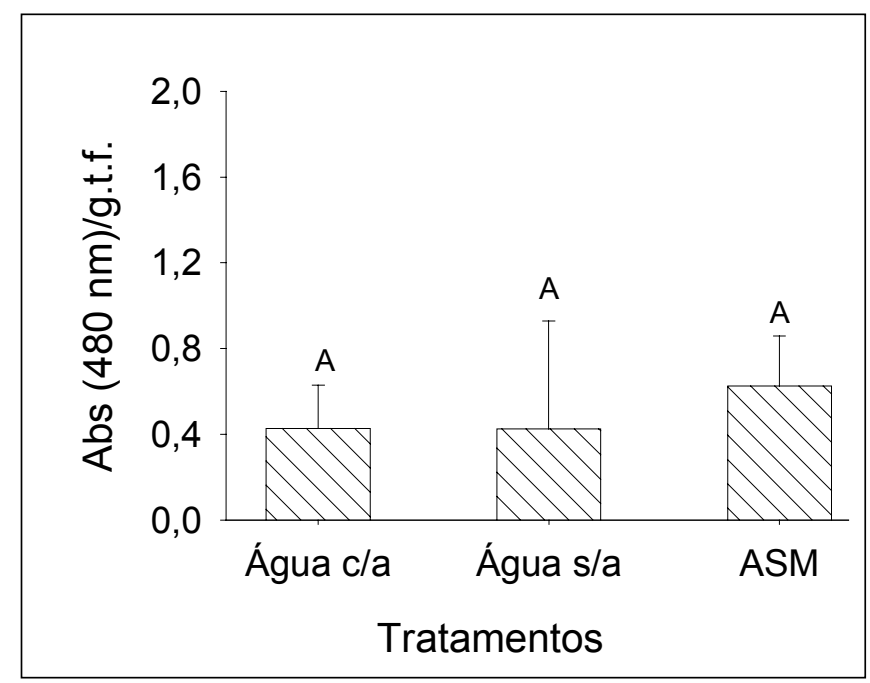

Figura 10 - Acúmulo de fitoalexinas em mesocótilos de sorgo após tratamento com água + antibiótico (c/a); água sem antibiótico (água s/a) e acibenzolar-S-metil (ASM). Médias seguidas da mesma letra não são significativamente diferentes entre si (teste de Tukey $\mathrm{P}=0,01$ ). As barras representam o desvio padrão da média de 5 repetições. CV $=69,19 \%$

\subsubsection{Efeito de preparações de Saccharomyces cerevisiae com concentração original de carboidratos na produção de fitoalexinas}

Mesocótilos de sorgo aspergidos com as preparações elicitoras (autoclavadas uma vez ou seqüencialmente, por horas ou minutos) ou com as frações parcialmente purificadas obtidas a partir de S. cerevisiae (item 4.5.1), apresentaram coloração característica das fitoalexinas de sorgo, com os tecidos variando a coloração em intensidade do laranja ao vermelho (Figura 11). O tempo de coleta dos mesocótilos foi estabelecido em 65 horas, período no qual as fitoalexinas já foram sintetizadas e são extraídas pelo solvente, apresentando pico máximo de absorbância na região de 480 nm (Wulff, 1997) (Figura 12). 


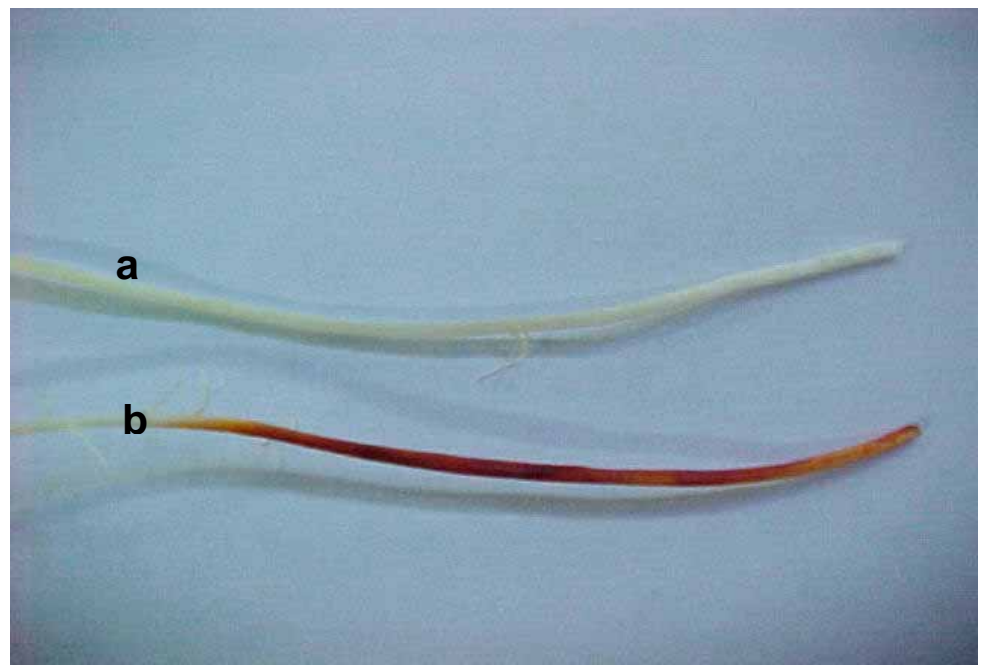

Figura 11 - Mesocótilos de sorgo aspergidos com água (a) ou preparação de Saccharomyces cerevisiae autoclavada por 4 horas seqüencialmente (b). Fotografia obtida 65 horas após o tratamento. Observar a coloração em (b)

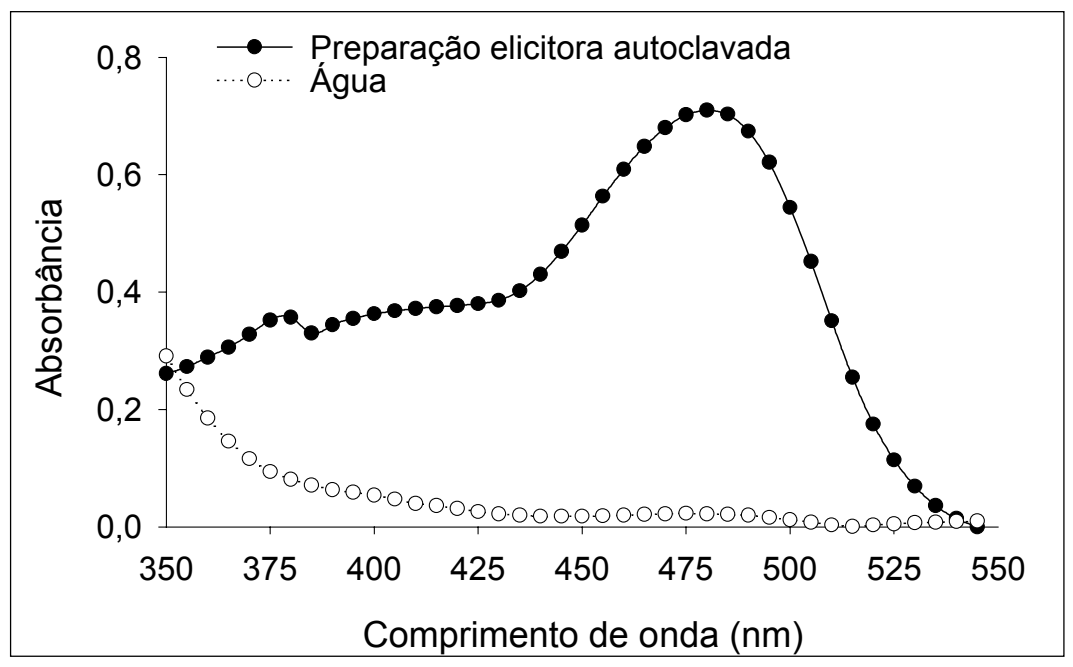

Figura 12 - Espectro de absorbância do extrato metanólico obtido de mesocótilos de sorgo tratados com a preparação elicitora de Saccharomyces cerevisiae, autoclavada por 4 horas seqüencialmente ou com água. Extrato metanólico obtido de mesocótilos, 65 horas após o tratamento elicitor 
No bioensaio de produção de fitoalexinas em mesocótilos de sorgo objetivando avaliar o efeito das preparações de $S$. cerevisiae com concentração original de carboidratos, utilizou-se mesocótilos previamente tratados ou não com o abrasivo carborundum. Foram conduzidos dois experimentos, sendo escolhido o melhor resultado para a ilustração dos resultados obtidos.

Nas Figuras 13 e 14, são apresentados os resultados da produção de fitoalexinas em mesocótilos de sorgo aspergidos com as preparações de $S$. cerevisiae autoclavada uma vez ou seqüencialmente, por minutos ou horas, respectivamente. Todas as preparações promoveram o acúmulo das fitoalexinas, sendo que as preparações autoclavadas seqüencialmente promoveram maior acúmulo das fitoalexinas, principalmente quando os mesocótilos foram tratados com preparações submetidas a autoclavagem por horas.

Os resultados da produção de fitoalexinas em mesocótilos de sorgo, previamente tratados com abrasivo carborundum e em seguida aspergidos com as preparações de S. cerevisiae, são apresentados nas Figuras 15 e 16. Todas as preparações promoveram o acúmulo de fitoalexinas nos mesocótilos de sorgo, sendo que novamente houve uma tendência de maior acúmulo de fitoalexinas nos mesocótilos aspergidos com as preparações autoclavadas seqüencialmente.

Quando se compara a produção de fitoalexinas em mesocótilos de sorgo, sem e com tratamento prévio com abrasivo carborundum, observa-se maior acúmulo nos mesocótilos que receberam o tratamento prévio. 


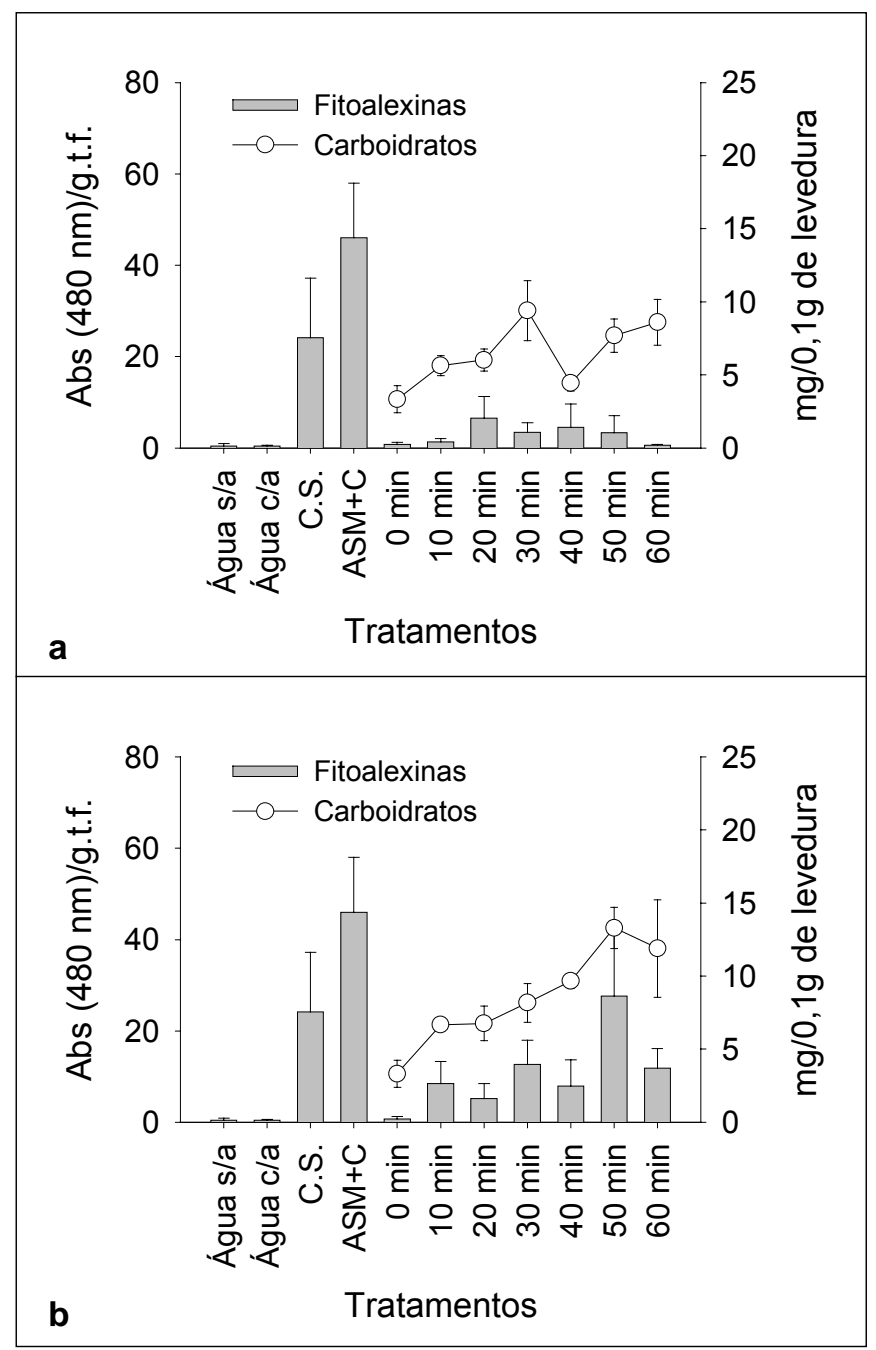

Figura 13 - Produção de fitoalexinas em mesocótilos de sorgo, sem tratamento prévio com abrasivo carborundum, aspergidos com preparações de Saccharomyces cerevisiae autoclavadas por minutos, com concentração original de carboidratos; (a). Preparações autoclavadas uma vez; (b). Preparações autoclavadas seqüencialmente. Água s/a: água sem antibiótico; Água c/a: água com antibiótico; $\mathrm{ASM}+\mathrm{C}$ : mesocótilos previamente tratados com abrasivo carborundum e aspergidos com acibenzolar-S-metil (50 ppm) e C.s.: Colletotrichum sublineolum $\left(1 \times 10^{5}\right.$ esporos $\left./ \mathrm{mL}\right)$. As barras representam o desvio padrão da média de 5 repetições 


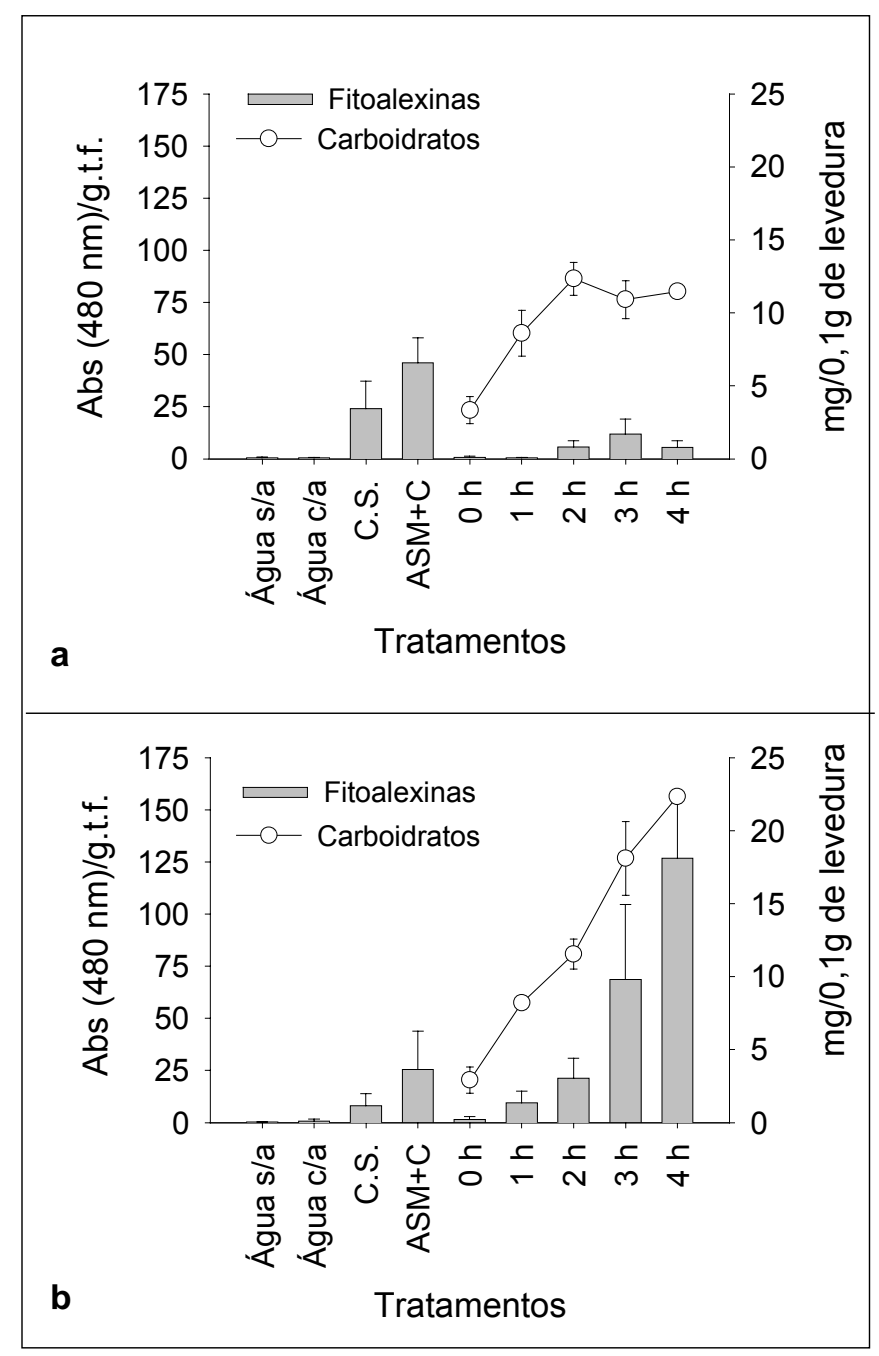

Figura 14 - Produção de fitoalexinas em mesocótilos de sorgo, sem tratamento prévio com abrasivo carborundum, aspergidos com preparações de Saccharomyces cerevisiae autoclavadas por horas, com concentração original de carboidratos; (a). Preparações autoclavadas uma vez; (b). Preparações autoclavadas seqüencialmente. Água s/a: água sem antibiótico; Água c/a: água com antibiótico; $\mathrm{ASM}+\mathrm{C}$ : mesocótilos previamente tratados com abrasivo carborundum e aspergidos com acibenzolar-S-metil (50ppm) e C.s.: Colletotrichum sublineolum ( $1 \times 10^{5}$ esporos $\left./ \mathrm{mL}\right)$. As barras representam o desvio padrão da média de 5 repetições 


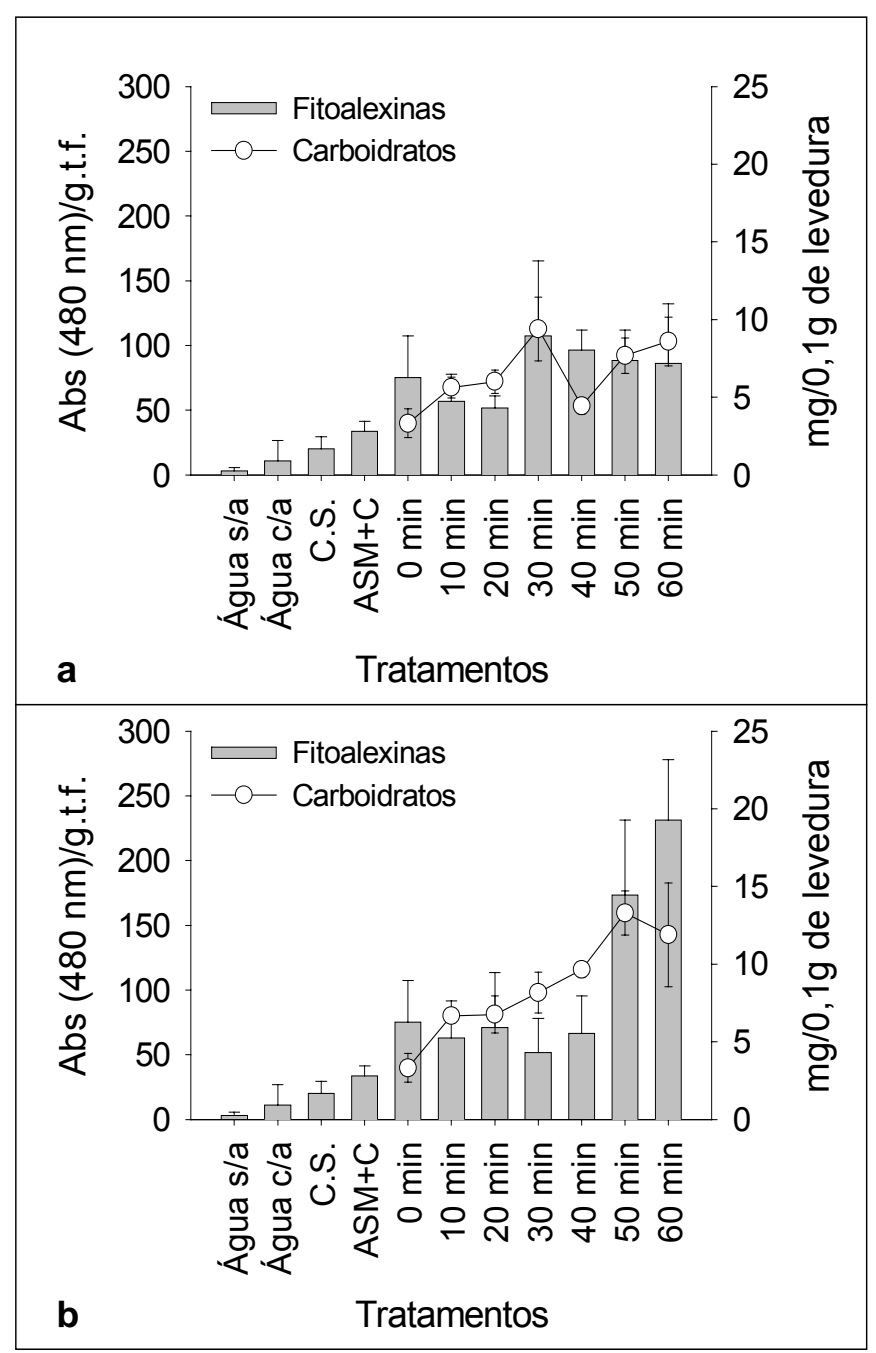

Figura 15 - Produção de fitoalexinas em mesocótilos de sorgo, previamente tratados com abrasivo carborundum, aspergidos com preparações de Saccharomyces cerevisiae autoclavadas por minutos, com concentração original de carboidratos; (a). Preparações autoclavadas uma vez; (b). Preparações autoclavadas seqüencialmente. Água s/a: água sem antibiótico; Água c/a: água com antibiótico; $\mathrm{ASM}+\mathrm{C}$ : mesocótilos previamente tratados com abrasivo carborundum e aspergidos com acibenzolar-S-metil (50 ppm) e C.s.: Colletotrichum sublineolum ( $1 \times 10^{5}$ esporos $\left./ \mathrm{mL}\right)$. As barras representam o desvio padrão da média de 5 repetições 


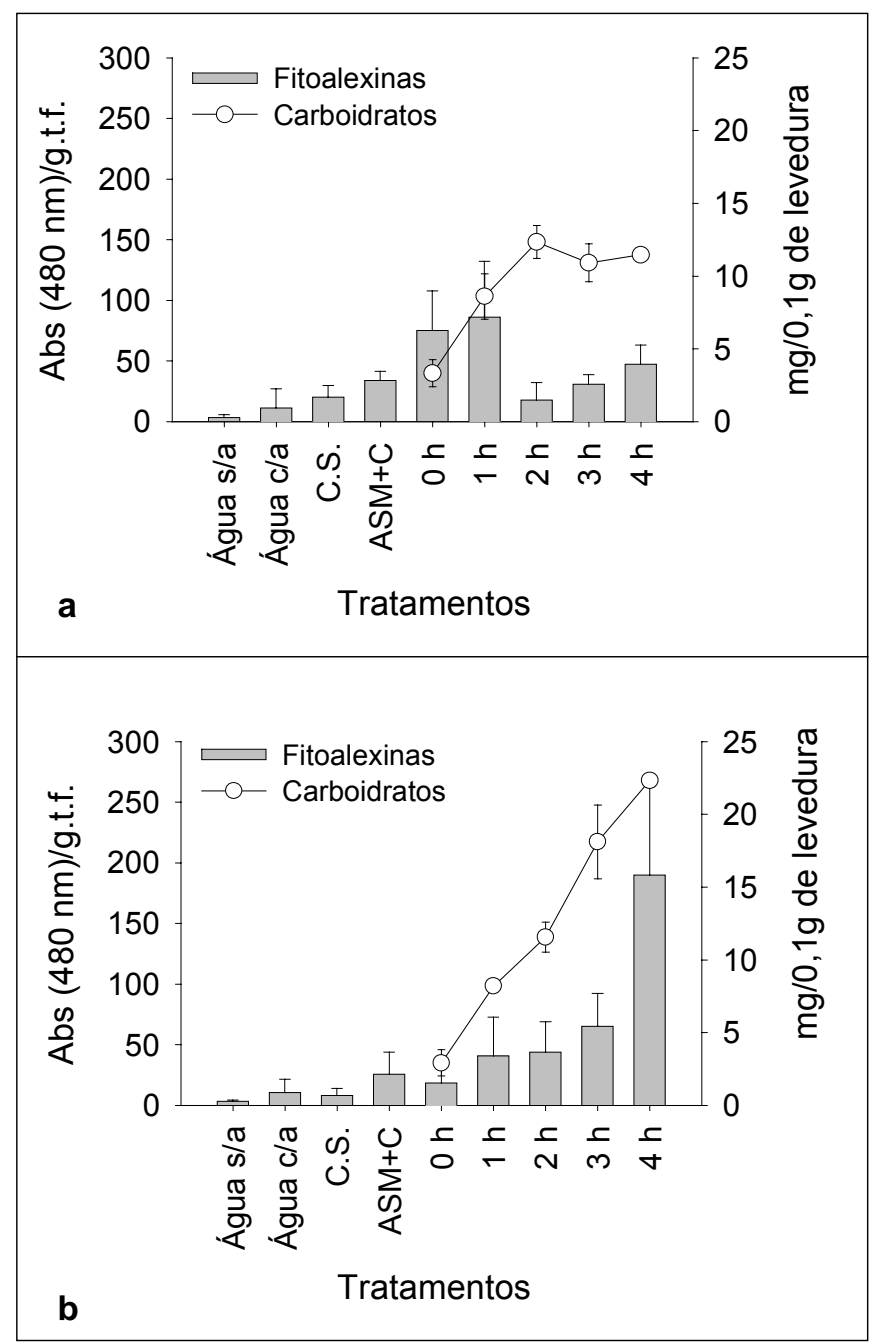

Figura 16 - Produção de fitoalexinas em mesocótilos de sorgo, previamente tratados com abrasivo carborundum, aspergidos com preparações de Saccharomyces cerevisiae autoclavadas por horas, com concentração original de carboidratos; (a). Preparações autoclavadas uma vez; (b). Preparações autoclavadas seqüencialmente. Água s/a: água sem antibiótico; Água c/a: água com antibiótico; $\mathrm{ASM}+\mathrm{C}$ : mesocótilos previamente tratados com abrasivo carborundum e aspergidos com acibenzolar-S-metil (50 ppm) e C.s.: Colletotrichum sublineolum ( $1 \times 10^{5}$ esporos $\left./ \mathrm{mL}\right)$. As barras representam o desvio padrão da média de 5 repetições 


\subsubsection{Efeito de preparações de Saccharomyces cerevisiae com concentração reduzida de carboidratos na produção de fitoalexinas}

Foram conduzidos dois experimentos sendo escolhido o melhor resultado para a ilustração dos resultados obtidos (Figuras 17 e 18). Em ambos os experimentos as concentrações de carboidratos foram ajustadas para a concentração da preparação com menor concentração de carboidratos, ou seja, foram ajustadas para a concentração de carboidratos da preparação de $S$. cerevisiae sem autoclavagem (tempo 0 min).

Todas as preparações autoclavadas uma vez ou seqüencialmente promoveram o acúmulo de fitoalexinas em mesocótilos de sorgo, previamente tratados ou não com abrasivo carborundum. Houve uma tendência de preparações autoclavadas seqüencialmente apresentarem maior atividade elicitora em mesocótilos de sorgo. Mesocótilos previamente tratados com abrasivo carborundum apresentaram maior acúmulo de fitoalexinas.

Por sua vez, quando as preparações de S. cerevisiae (tempos 0 , 30 e 60 min e 2 e 4 horas, autoclavadas uma vez ou seqüencialmente) com concentração de carboidratos ajustada para a concentração da preparação de S. cerevisiae sem autoclavagem (tempo 0) e diluídas 10, 100, 1.000 e 10.000 vezes foram testadas na produção de fitoalexinas em mesocótilos de sorgo sem ou com tratamento prévio com carborundum, observou-se que todas as preparações, mesmo diluídas 10.000 vezes induziram o acúmulo das fitoalexinas, sendo que o acúmulo foi maior em mesocótilos previamente tratados com carborundum (dados não mostrados). 


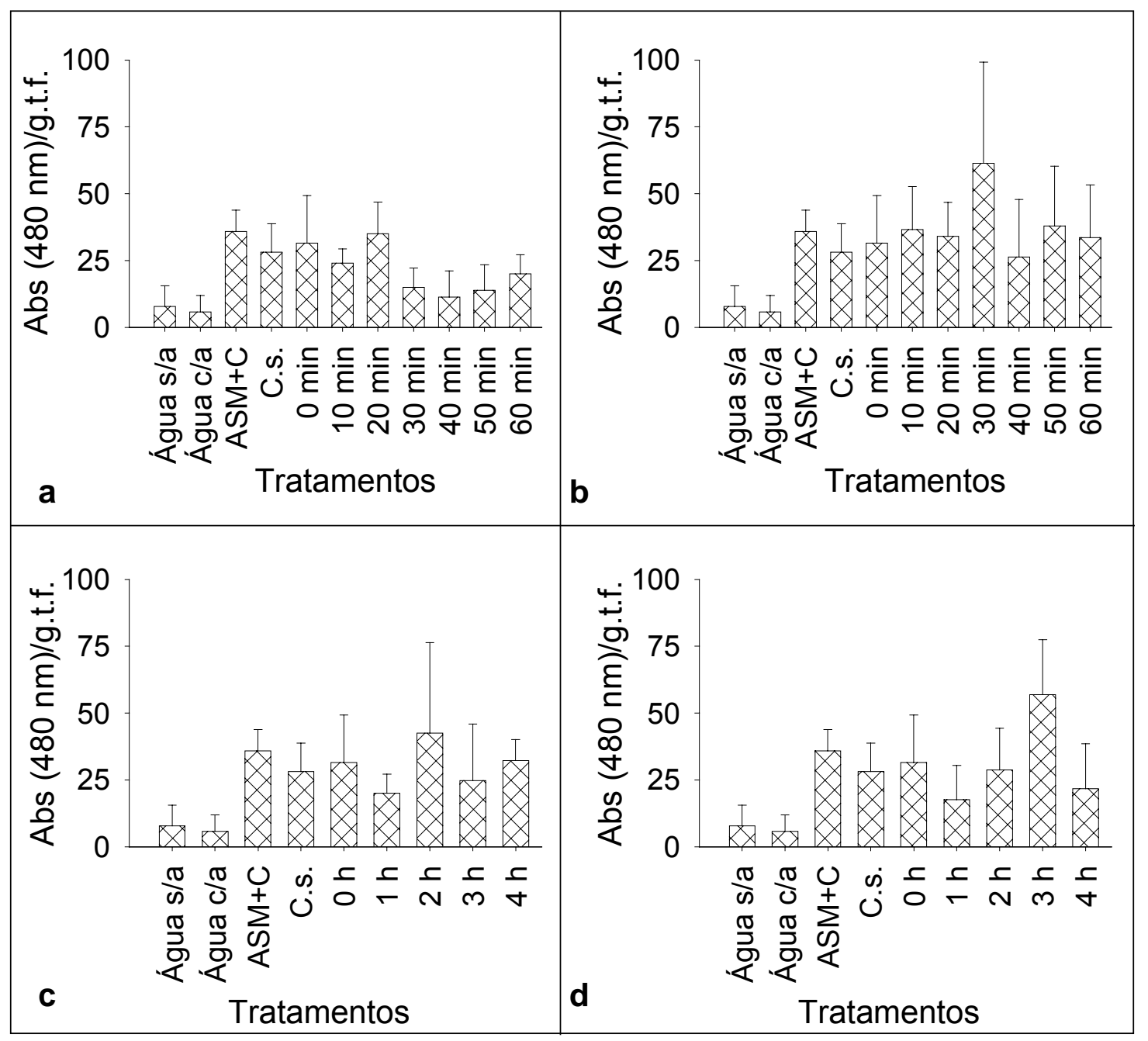

Figura 17 - Produção de fitoalexinas em mesocótilos de sorgo aspergidos com preparações de Saccharomyces cerevisiae autoclavadas por minutos ou horas, com concentração de carboidratos ajustada para a concentração da preparação de S. cerevisiae sem autoclavagem (tempo 0); (a) e (c). Preparações autoclavadas uma vez; (b) e (d). Preparações autoclavadas seqüencialmente. Água s/a: água sem antibiótico; Água c/a: água com antibiótico; $\mathrm{ASM}+\mathrm{C}$ : mesocótilos previamente tratados com abrasivo carborundum e aspergidos com acibenzolar-S-metil (50 ppm) e C.s.: Colletotrichum sublineolum $\left(1 \times 10^{5}\right.$ esporos $\left./ \mathrm{mL}\right)$. As barras representam o desvio padrão da média de 5 repetições 


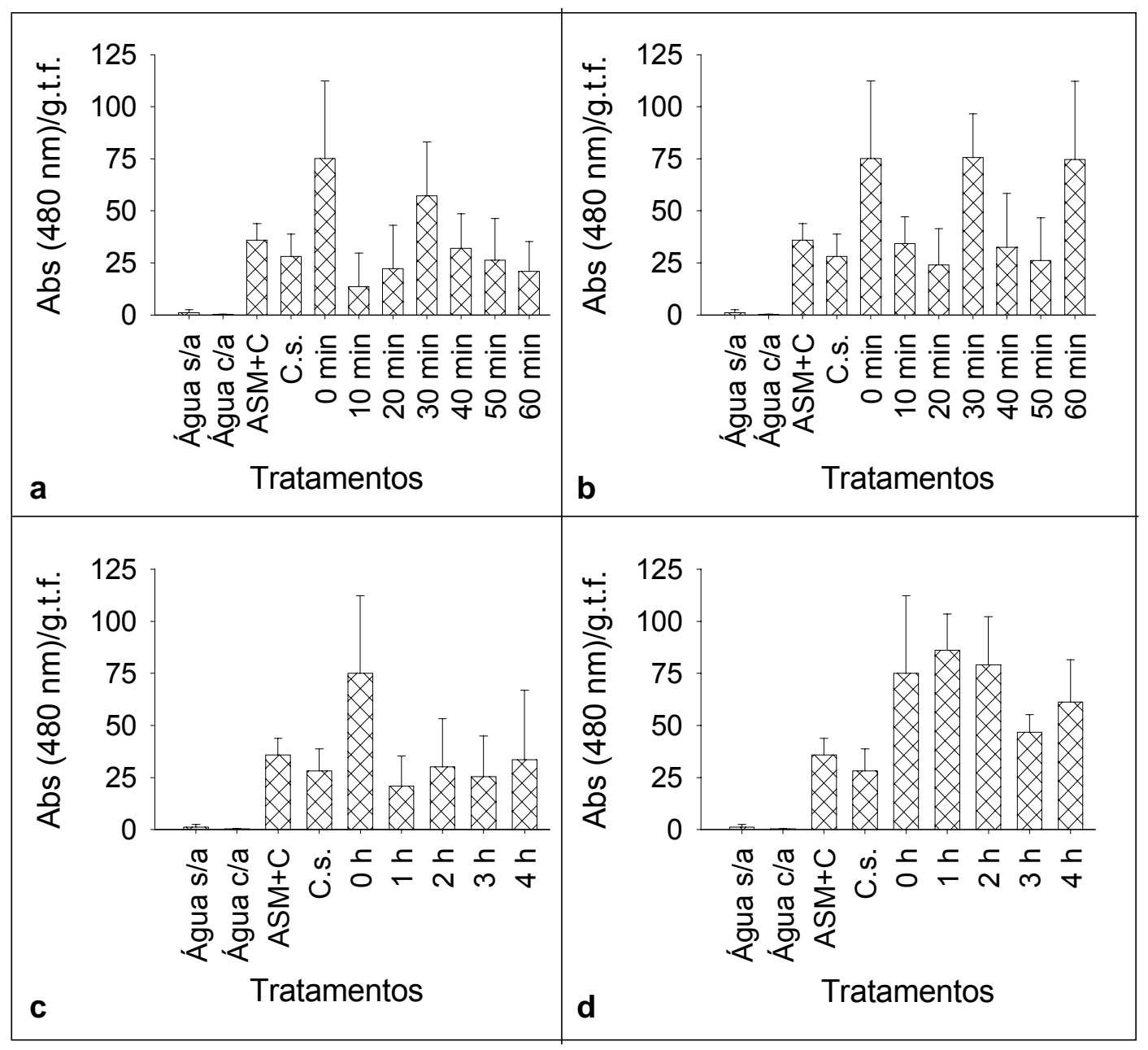

Figura 18 - Produção de fitoalexinas em mesocótilos de sorgo, previamente tratados com abrasivo carborundum, aspergidos com preparações de Saccharomyces cerevisiae autoclavadas por minutos ou horas, com concentração de carboidratos ajustada para a concentração da preparação de S. cerevisiae sem autoclavagem (tempo 0); (a) e (c). Preparações autoclavadas uma vez; (b) e (d). Preparações autoclavadas seqüencialmente. Água s/a: água sem antibiótico; Água c/a: água com antibiótico; $A S M+C$ : mesocótilos previamente tratados com abrasivo carborundum e aspergidos com acibenzolar-S-metil (50 ppm) e C.s.: Colletotrichum sublineolum $\left(1 \times 10^{5}\right.$ esporos $\left./ \mathrm{mL}\right)$. As barras representam o desvio padrão da média de 5 repetições 


\subsubsection{Curva dose resposta da preparação elicitora de Saccharomyces cerevisiae na produção de fitoalexinas em sorgo}

Como houve maior solubilização das moléculas elicitoras mediante autoclavagem por 4 horas seqüencialmente, permitindo maior rendimento para o passo seguinte de purificação, esta preparação foi utilizada para a elaboração de uma curva dose resposta.

Foram realizados quatro experimentos para se avaliar o efeito de concentrações crescentes da preparação de $S$. cerevisiae, na produção de fitoalexinas em mesocótilos de sorgo, sendo um dos experimentos escolhido para ilustrar os resultados obtidos (Figura 19). Pela análise de regressão não linear obtida verificou-se que mesocótilos de sorgo, previamente tratados ou não com abrasivo carborundum, apresentaram o mesmo comportamento em relação à produção de fitoalexinas quando tratados com diferentes concentrações de carboidratos na preparação de S. cerevisiae, autoclavada por 4 horas seqüencialmente. Porém, o acúmulo de fitoalexinas foi maior em mesocótilos previamente tratados com abrasivo carborundum.

As curvas ajustadas para o acúmulo de fitoalexinas em mesocótilos de sorgo, apresentaram tendência de maiores aumentos da produção das fitoalexinas em baixas concentrações de carboidratos da preparação de S. cerevisiae. A partir da concentração de $18,21 \mathrm{mg}$ de carboidratos $/ 0,1 \mathrm{~g}$ de levedura, observa-se que ocorre um lento aumento no acúmulo das fitoalexinas em função dos valores crescentes de carboidratos na preparação elicitora, com uma tendência à estabilização da produção de fitoalexinas. 


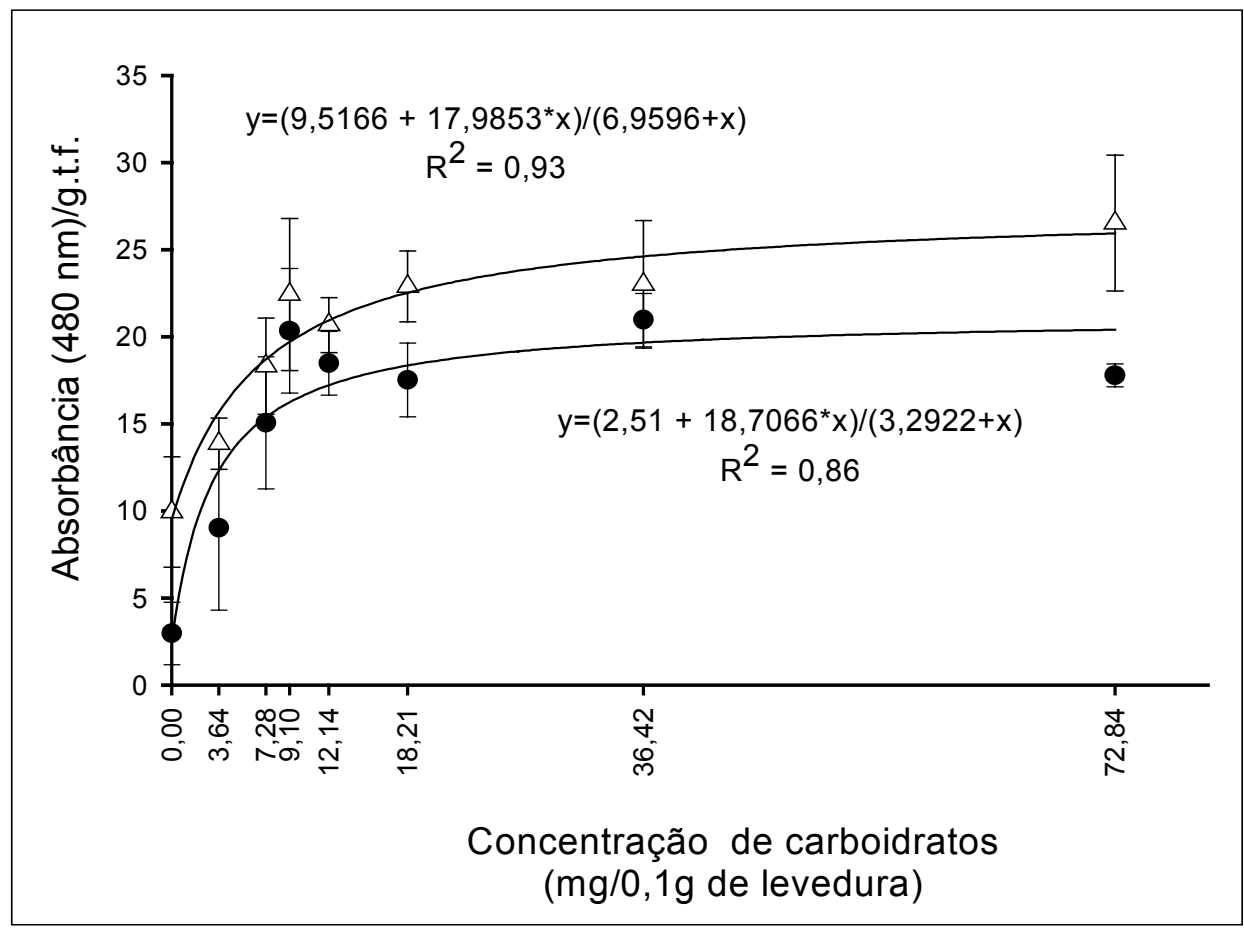

Figura 19 - Efeito de concentrações crescentes da preparação de Saccharomyces cerevisiae autoclavada por 4 horas seqüencialmente na produção de fitoalexinas em mesocótilos de sorgo. (--•--) Mesocótilos sem tratamento prévio. (- $\Delta-)$ Mesocótilos previamente tratados com abrasivo carborundum. As barras representam o desvio padrão da média de 5 repetições

\subsubsection{Produção de fitoalexinas em mesocótilos de sorgo após diferentes tempos de incubação}

A produção de fitoalexinas em mesocótilos de sorgo, tratados com a preparação de $S$. cerevisiae autoclavada por 4 horas seqüencialmente, com o 
patógeno $C$. sublineolum ou água destilada esterilizada, em diferentes tempos de incubação pode ser observada na Figura 20.

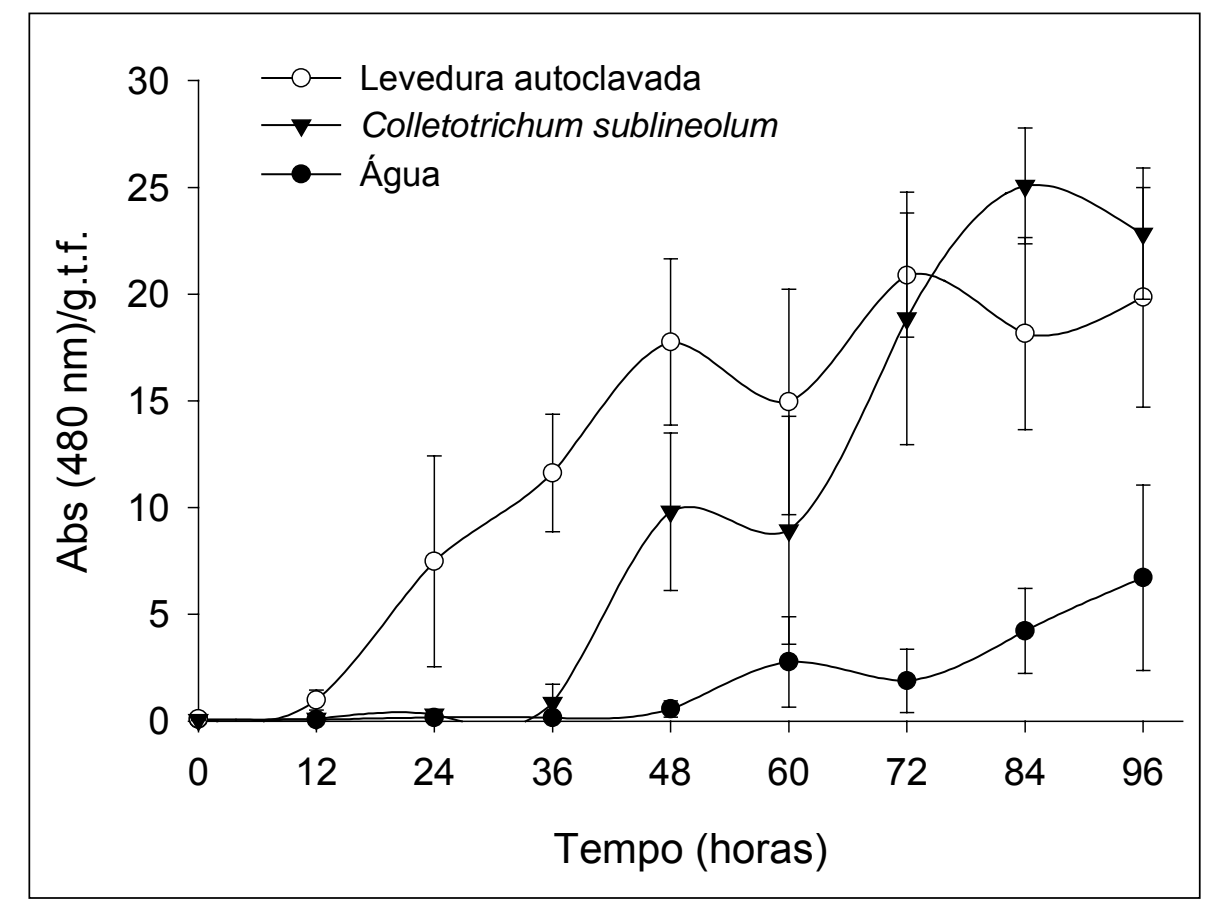

Figura 20 - Produção de fitoalexinas em mesocótilos de sorgo, em diferentes tempos de incubação, após tratamento com água destilada esterilizada, preparação de Saccharomyces cerevisiae autoclavada por 4 horas seqüencialmente e Colletotrichum sublineolum. As barras representam o desvio padrão da média de 5 repetições

Mesocótilos tratados com a preparação da levedura iniciaram o acúmulo de fitoalexinas após 12 horas do tratamento elicitor, enquanto que mesocótilos tratados com C. sublineolum (controle positivo), iniciaram o acúmulo de fitoalexinas após 36 horas de incubação. A preparação de $S$. cerevisiae apresentou a maior produção de fitoalexinas até 72 horas após o tratamento elicitor. 
4.3 Germinação de esporos e formação de apressórios por Colletotrichum lagenarium e Colletotrichum sublineolum

\subsubsection{Efeito de preparações de Saccharomyces cerevisiae com concentração original de carboidratos na germinação de esporos e formação de apressórios}

Todas as preparações de S. cerevisiae com concentração original de carboidratos induziram a germinação de esporos de C. lagenarium e C. sublineolum, sem a formação de apressórios (Figuras 21 e 22, respectivamente), em dois experimentos conduzidos, sendo apresentado apenas um dos resultados obtidos. Observou-se que os tubos germinativos emitidos por $C$. lagenarium e $C$. sublineolum apresentaram em média tamanho superior a 10 vezes o tamanho do esporo (dados não mostrados). Como os tratamentos controles, água destilada esterilizada com e sem antibiótico foram os mesmos para todos os bioensaios com as preparações de S. cerevisiae, onde as preparações promoveram 100\% de germinação de esporos, os gráficos são visualmente idênticos (Figuras 21 e 22). 


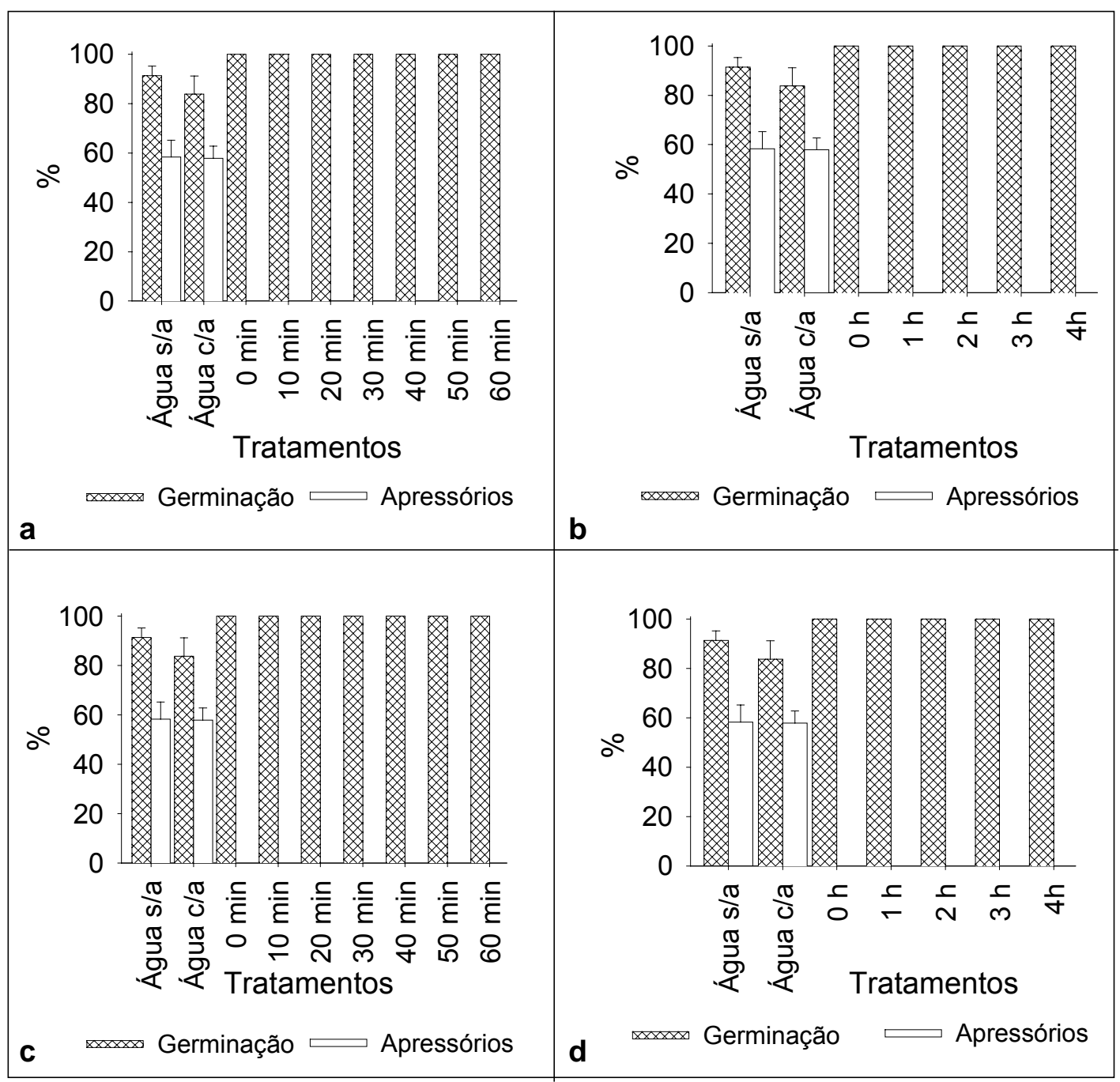

Figura 21 - Germinação de esporos e formação de apressórios por Colletotrichum lagenarium na presença de preparações de Saccharomyces cerevisiae autoclavadas por minutos ou horas, com concentração original de carboidratos; (a) e (c). Preparações autoclavadas uma vez; (b) e (d). Preparações autoclavadas seqüencialmente. Concentração do inóculo do patógeno: 1 × $10^{5}$ esporos $/ \mathrm{mL}$. Água s/a: água sem antibiótico; Água c/a: água com antibiótico As barras representam o desvio padrão da média de 8 repetições 


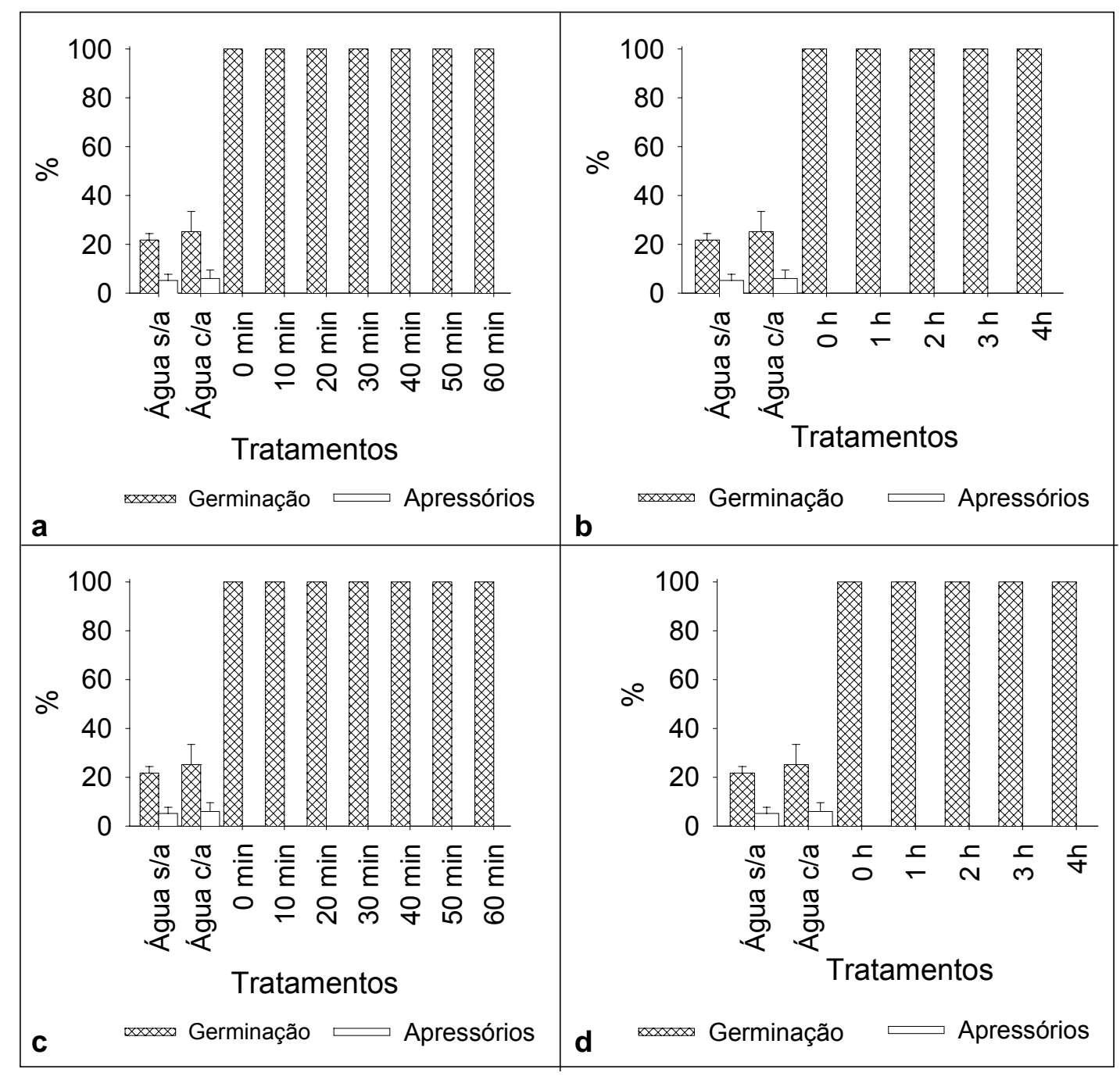

Figura 22 - Germinação de esporos e formação de apressórios por Colletotrichum sublineolum na presença de preparações de Saccharomyces cerevisiae autoclavadas por minutos ou horas, com concentração original de carboidratos. (a) e (c) Preparações autoclavadas uma vez. (b) e (d) Preparações autoclavadas seqüencialmente. Concentração do inóculo do patógeno: 1 × $10^{5}$ esporos $/ \mathrm{mL}$. Água s/a: água sem antibiótico; Água c/a: água com antibiótico As barras representam o desvio padrão da média de 8 repetições 


\subsubsection{Efeito de preparações de Saccharomyces cerevisiae com concentração reduzida de carboidratos na germinação de esporos e formação de apressórios}

As preparações de $S$. cerevisiae autoclavadas em diferentes tempos, uma vez ou seqüencialmente, tiveram a concentração de carboidratos ajustada para a concentração da preparação de S. cerevisiae não autoclavada (menor concentração de carboidratos). Houve 100\% de germinação de esporos de $C$. lagenarium e $C$. sublineolum, sem a formação de apressórios, em todas as preparações testadas. Tubos germinativos emitidos por $C$. lagenarium e $C$. sublineolum apresentaram tamanho superior a 10 vezes o tamanho do esporo (dados não mostrados).

\subsubsection{Curva dose resposta da preparação de Saccharomyces cerevisiae, autoclavada por 4 horas seqüencialmente, na germinação de esporos e formação de apressórios}

Houve favorecimento da germinação de esporos e formação de apressórios de $C$. lagenarium nas concentrações de 2,23 a 11,16 mg de carboidratos/0,1 g de levedura. $\mathrm{Na}$ concentração de $22,32 \mathrm{mg}$ de carboidratos/0,1 g de levedura houve apenas estímulo da germinação de esporos, sem a formação de apressórios (Tabela 3). Alteração na morfologia dos tubos germinativos de $C$. lagenarium foi observada. Em baixas concentrações $(2,23$ a $3,57 \mathrm{mg}$ de carboidratos/0,1 g de levedura), os tubos germinativos apresentaram cerca de 2 vezes o tamanho do esporo. $\mathrm{Na}$ concentração de $5,58 \mathrm{mg}$ de carboidratos/0,1 de levedura os tubos germinativos apresentaram 5 vezes o tamanho do esporo. Em concentrações altas $(11,16 \mathrm{e}$ $22,32 \mathrm{mg}$ de carboidratos/0,1 $\mathrm{g}$ de levedura) os tubos germinativos 
apresentaram um tamanho dez vezes maior que o tamanho do esporo (dados não mostrados).

Tabela 3. Efeito de concentrações crescentes de carboidratos na preparação de Saccharomyces cerevisiae, autoclavada por 4 horas seqüencialmente, na germinação de esporos e formação de apressórios de Colletotrichum lagenarium*

\begin{tabular}{ccc}
\hline $\begin{array}{c}\text { Concentração de carboidratos } \\
(\mathrm{mg} / 0,1 \mathrm{~g} \text { de levedura })\end{array}$ & $\begin{array}{c}\text { Germinação de } \\
\text { esporos }(\%)^{* *}\end{array}$ & $\begin{array}{c}\text { Formação de } \\
\text { apressórios }(\%)^{\star *}\end{array}$ \\
\hline 0 & 0 & 0 \\
2,23 & 100 & 100 \\
2,79 & 100 & 100 \\
3,57 & 100 & 100 \\
5,58 & 100 & 100 \\
11,16 & 100 & 100 \\
22,32 & 100 & 0
\end{tabular}

* Suspensão de esporos utilizada no bioensaio: $1,5 \times 10^{5}$ esporos $/ \mathrm{mL}$

** Média de oito repetições

Para C. sublineolum as concentrações de 2,23 a $5,58 \mathrm{mg}$ de carboidratos $/ 0,1 \mathrm{~g}$ de levedura estimularam a germinação de esporos e a formação de apressórios. Nas concentrações 11,16 e 22,32 mg de carboidratos/0,1 g de levedura houve apenas estímulo da germinação de esporos, sem a formação de apressórios (Tabela 4). Houve diferença com relação ao tamanho dos tubos germinativos emitidos pelos esporos. Tubos curtos (2 vezes o tamanho do esporo) foram observados em concentrações de 2,23 e 2,79; $\mathrm{mg}$ de carboidratos/0,1 g de levedura. Nas demais concentrações avaliadas, os tubos germinativos apresentaram um tamanho dez vezes maior que o tamanho do esporo (dados não mostrados). 
Tabela 4. Efeito de concentrações crescentes de carboidratos na preparação de Saccharomyces cerevisiae, autoclavada por 4 horas seqüencialmente, na germinação de esporos e formação de apressórios de Colletotrichum sublineolum*

\begin{tabular}{ccc}
\hline $\begin{array}{c}\text { Concentração de carboidratos } \\
(\mathrm{mg} / 0,1 \mathrm{~g} \text { de levedura })\end{array}$ & $\begin{array}{c}\text { Germinação de } \\
\text { esporos }(\%)^{* *}\end{array}$ & $\begin{array}{c}\text { Formação de } \\
\text { apressórios }(\%)^{* *}\end{array}$ \\
\hline 0 & 49,7 & 7,8 \\
2,23 & 100 & 100 \\
2,79 & 100 & 100 \\
3,57 & 100 & 100 \\
5,58 & 100 & 100 \\
11,16 & 100 & 0 \\
22,32 & 100 & 0 \\
\hline
\end{tabular}

${ }^{*}$ Suspensão de esporos utilizada no bioensaio: $1 \times 10^{5}$ esporos $/ \mathrm{mL}$

** Média de oito repetições

\subsection{Espectrofotometria de infravermelho}

$\mathrm{Na}$ análise usando espectrofotometria na região do infravermelho, comparando os espectros obtidos com dados da literatura que descrevem bandas de absorção em espectros de infravermelho microbial, as seguintes bandas foram detectadas nas preparações de levedura sem autoclavagem ou com 4 horas de autoclavagem seqüencialmente (Figura 23):

a) $4000-3400 \mathrm{~cm}^{-1}$ - bandas largas resultantes de estiramento $\mathrm{OH}\left(\sim 3400 \mathrm{~cm}^{-1}\right)$ e N-H (amida A $\sim 3300 \mathrm{~cm}^{-1}$ e amida B $\sim 3030 \mathrm{~cm}^{-1}$ );

b) $1300-1500 \mathrm{~cm}^{-1}$ - predominantemente, $=\mathrm{CH}_{2}$ e $-\mathrm{CH}$ de lipídios e proteínas; 
c) $1200-900 \mathrm{~cm}^{-1}$ - vibrações de estiramento simétrico de grupos $\mathrm{PO}_{2}^{-}$em ácidos nucléicos e uma seqüência complexa de picos devido principalmente a vibrações de estiramento $\mathrm{C}-\mathrm{O}-\mathrm{C}$ e C-O-P de vários oligo- e polissacarídeos.

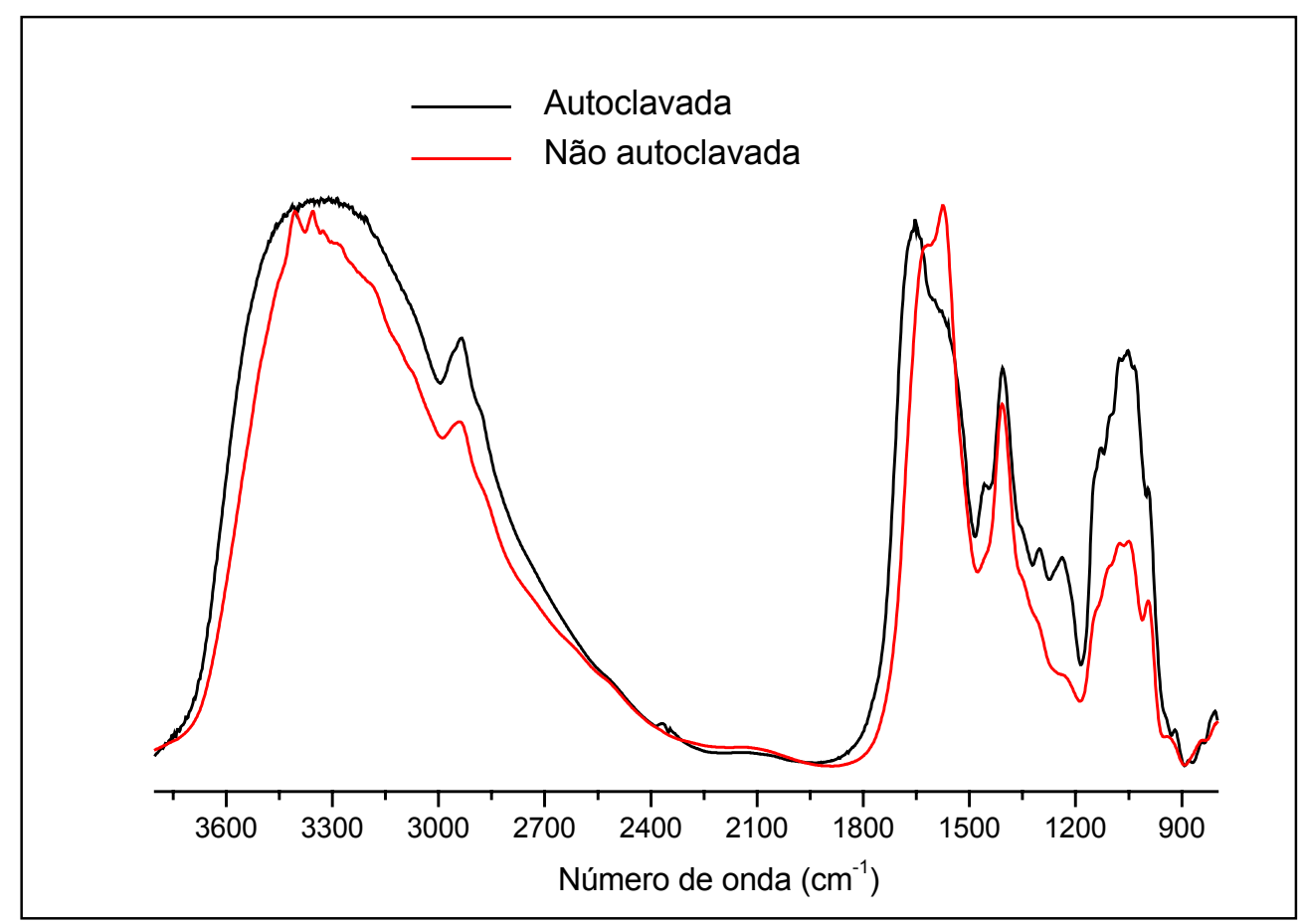

Figura 23 - Espectro na região do infravermelho de preparações de Saccharomyces cerevisiae autoclavada por 4 horas seqüencialmente ou não autoclavada

Como a banda de proteínas foi igualada nos espectros de absorção obtidos (Figura 23) é possível observar que a preparação de $S$. cerevisiae autoclavada por 4 horas seqüencialmente apresenta mais polissacarídeos que a preparação não autoclavada. 


\subsection{Separação dos componentes da preparação elicitora de Saccharomyces cerevisiae por cromatografia de troca iônica}

Considerando que nos bioensaios de fitoalexinas em mesocótilos de sorgo e germinação de esporos e formação de apressórios por fitopatógenos fúngicos, não ocorreram diferenças relevantes entre as preparações testadas, e como a preparação elicitora autoclavada por 4 horas seqüencialmente apresentou maior concentração de carboidratos, como já comentado, passouse à etapa de purificação utilizando esta preparação. Em função de experimentos prévios mostrarem a perda de carboidratos e de proteínas da preparação de S. cerevisiae durante a etapa de diálise e tornarem o processo de purificação demorado, procurou-se efetuar uma adaptação da etapa de purificação por CTI, avaliando-se o emprego dos tampões Tris- $\mathrm{HCl}$ e bicarbonato de amônio para eluição da coluna.

As CTIs utilizando tampão $\mathrm{Tris}-\mathrm{HCl}$ foram realizadas com gradiente linear de $\mathrm{NaCl}$ no mesmo tampão ou "step wise" para eluição de proteínas ligadas à resina DEAE-Celulose. Entretanto, são apresentados apenas os resultados da CTI com o procedimento "step wise", devido a melhor separação dos compostos. De acordo com o perfil de proteínas das frações obtidas estas foram agrupadas formando seis frações (Figura 24a) (Apêndice 3). A dosagem de carboidratos das frações agrupadas mostrou alta concentração de carboidratos na fração I, seguida pela fração III (Tabela 5). Com relação às proteínas, as frações III e $\mathrm{V}$ apresentaram as maiores concentrações e a fração II o menor conteúdo de proteínas. As frações obtidas na CTI e submetidas a diálise não apresentaram coloração.

Nas CTIs utilizando tampão bicarbonato de amônio utilizou-se gradiente linear com o próprio tampão ou "step wise" para eluição de proteínas ligadas à resina DEAE-Celulose, sendo apresentados os resultados da CTI com o procedimento "step wise", devida a melhor separação dos compostos. Foram obtidas sete frações após o reagrupamento das frações obtidas, de acordo com 
o perfil de proteínas (Figura 24b) (Apêndice 3). A fração I apresentou alta concentração de carboidratos (não ligados) seguida pela fração III, como observado na CTI com tampão Tris-HCl (Tabela 5). Com relação às proteínas a fração $V$ apresentou a maior concentração e a fração VII a menor concentração. As frações obtidas nesta CTI apresentaram variação na tonalidade (Figura 25), sendo que a fração I apresentou coloração mais escura quando comparada as demais frações.

Nos bioensaios de fitoalexinas em mesocótilos de sorgo (item 4.5.1), germinação de esporos e formação de apressórios por $C$. lagenarium e C. sublineolum (item 4.5.2), proteção de plântulas de pepino (item 4.5.3) e de plantas de sorgo (item 4.5.5), as frações obtidas tiveram a concentração de proteínas ajustada de acordo com a menor concentração de proteínas das frações. Frações obtidas na primeira CTI foram ajustadas de acordo com a concentração de proteínas da fração II $(0,246 \mathrm{mg} / \mathrm{mL})$; e concentrações de proteínas das frações obtidas na segunda CTI foram igualadas a concentração de proteínas da fração VII $(0,391 \mathrm{mg} / \mathrm{mL})$. Porém, extrato bruto (levedura autoclavada por 4 horas seqüencialmente), foi utilizado nos bioensaios com a concentração original de proteínas $(1,135 \mathrm{mg} / \mathrm{mL})$ e de carboidratos $(20,17$ $\mathrm{mg} / 0,1 \mathrm{~g}$ de levedura). 


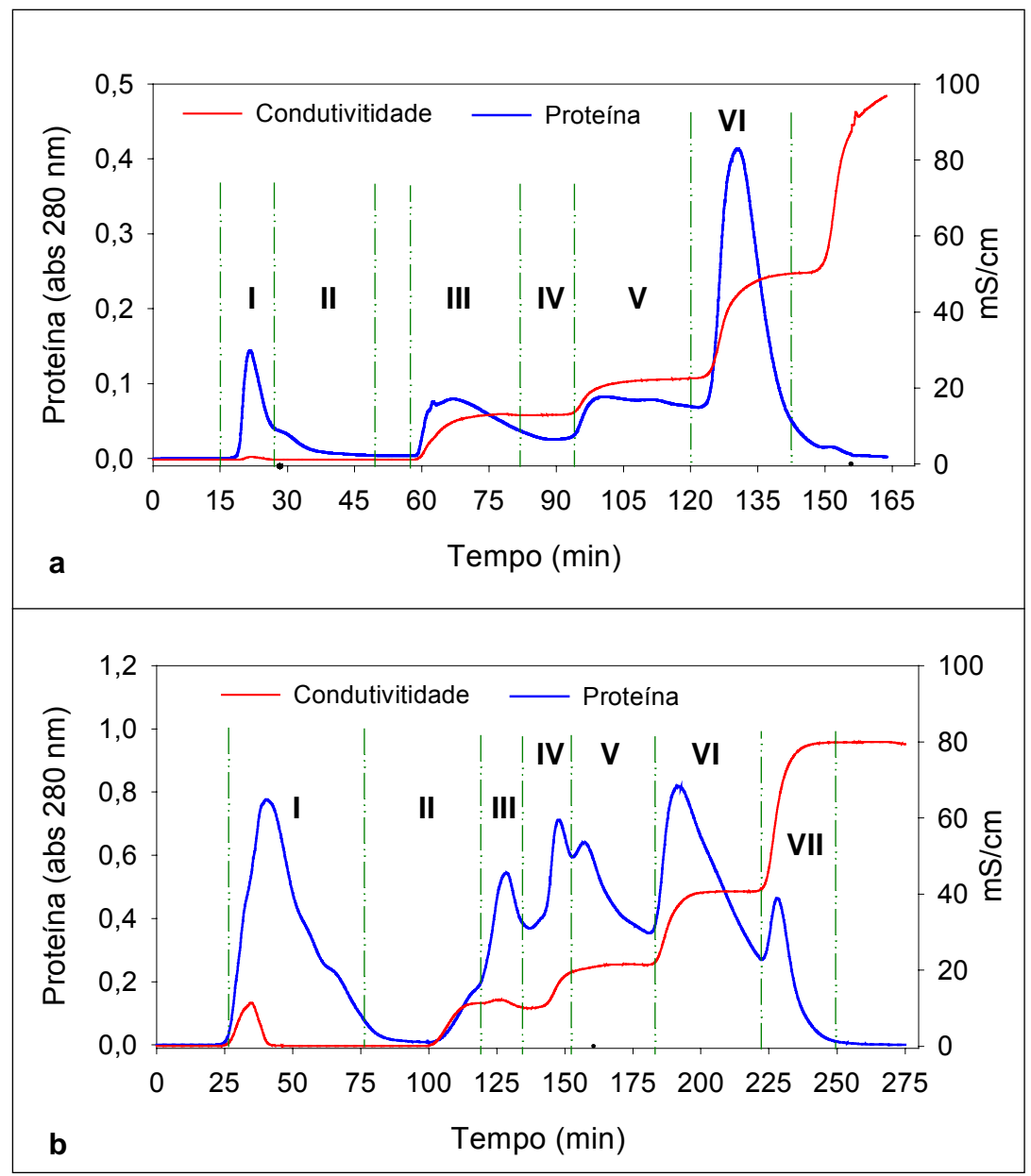

Figura 24 - Cromatografia de troca iônica da preparação de Saccharomyces cerevisiae autoclavada por 4 horas seqüencialmente, em coluna empacotada com a resina DEAE-Celulose; (a). Coluna equilibrada e eluída com tampão Tris$\mathrm{HCl}$ 0,01 M (pH 8,0); e eluição do material adsorvido à resina através de soluções de $\mathrm{NaCl}$ a 0,12 M (35 min), $021 \mathrm{M}$ (30 min), 0,50 M (25 min) e 1 M (25 min). As frações coletadas foram reagrupadas, conforme o perfil de proteínas para formação de 6 novas frações: I, II, III, IV, V e VI; (b). Coluna equilibrada e eluída com tampão bicarbonato de amônio 0,01 M (pH 8,0); e eluição do material adsorvido com o próprio tampão a 12,5 M (40 min), 25 M (40 min), 50 M (40 min) e 1 M (80 min). As frações coletadas foram reagrupadas, conforme o perfil de proteínas para formação de 7 novas frações: I, II, III, IV, V, VI e VII 
Tabela 5. Purificação parcial da preparação de Saccharomyces cerevisiae, autoclavada por 4 horas seqüencialmente, através de cromatografia de troca iônica (CTI)

\begin{tabular}{|c|c|c|c|c|}
\hline Etapas & $\begin{array}{l}\text { Proteínas } \\
\text { (mg) }\end{array}$ & $\begin{array}{c}\text { Recuperação } \\
\text { de } \\
\text { Proteínas } \\
(\%)\end{array}$ & $\begin{array}{l}\text { Carboidratos } \\
(\mathrm{mg})\end{array}$ & $\begin{array}{c}\text { Recuperação } \\
\text { de } \\
\text { carboidratos } \\
(\%)\end{array}$ \\
\hline $\begin{array}{l}\text { i) Extrato bruto } \\
\text { (Tampão Tris-HCl) }\end{array}$ & 84,8 & - & 358,30 & - \\
\hline Fração I & 5,82 & 6,86 & 206,06 & 57,51 \\
\hline Fração II & 3,69 & 4,35 & 3,09 & 0,86 \\
\hline Fração III & 10,38 & 12,24 & 51,28 & 14,31 \\
\hline Fração IV & 7,5 & 8,84 & 8,19 & 2,29 \\
\hline Fração V & 9,27 & 10,93 & 1,94 & 0,54 \\
\hline Fração VI & 6,41 & 7,56 & 2,26 & 0,63 \\
\hline $\begin{array}{l}\text { ii) Extrato bruto } \\
\text { (Tampão }\end{array}$ & 59,35 & - & $2.170,92$ & - \\
\hline $\begin{array}{l}\text { bicarbonato de } \\
\text { amônio) }\end{array}$ & & & & \\
\hline Fração I & 9,49 & 15,99 & 503,06 & 23,17 \\
\hline Fração II & 7,19 & 12,11 & 51,36 & 2,37 \\
\hline Fração III & 8,24 & 13,88 & 100,00 & 4,61 \\
\hline Fração IV & 9,12 & 15,37 & 17,34 & 0,80 \\
\hline Fração V & 10,53 & 17,74 & 3,23 & 0,15 \\
\hline Fração VI & 8,09 & 13,63 & 1,72 & 0,08 \\
\hline Fração VII & 3,91 & 6,59 & 12,26 & 0,56 \\
\hline
\end{tabular}

i) Preparação de Saccharomyces cerevisiae autoclavada por 4 horas seqüencialmente, liofilizada, dialisada e separada em CTI utilizando tampão Tris-HCl

ii) Preparação de Saccharomyces cerevisiae autoclavada por 4 horas seqüencialmente, liofilizada e separada em CTI utilizando tampão bicarbonato de amônio 


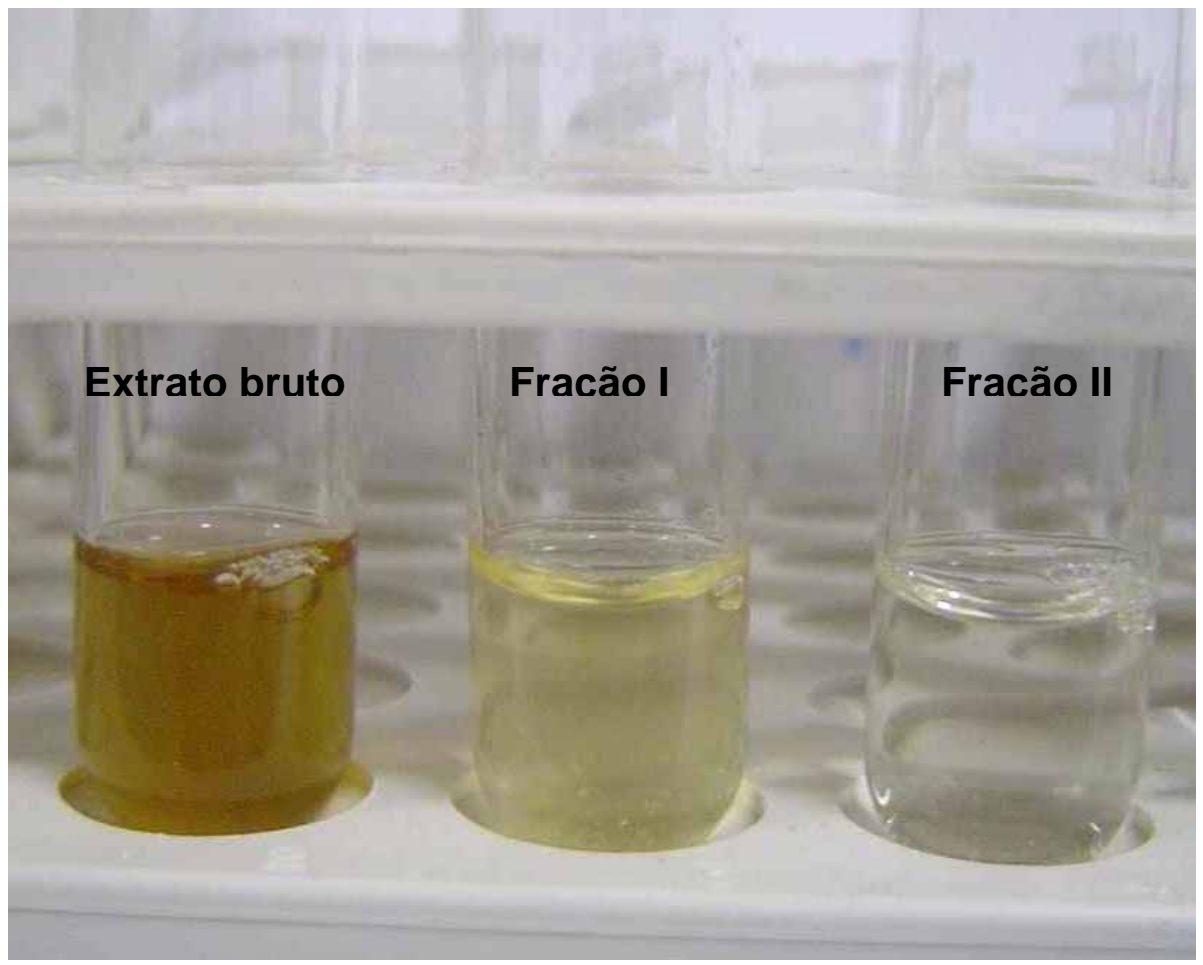

Figura 25 - Coloração da preparação de Saccharomyces cerevisiae autoclavada por 4 horas seqüencialmente e aplicada à coluna DEAE-Celulose, e das frações I e II obtidas após cromatografia de troca iônica com tampão bicarbonato de amônio

\subsubsection{Produção de fitoalexinas em sorgo}

\section{Produção de fitoalexinas em mesocótilos de sorgo}

A produção de fitoalexinas em mesocótilos de sorgo, previamente tratados ou não com abrasivo carborundum, por frações obtidas na CTI com tampão Tris- $\mathrm{HCl}$ (item 4.5) é apresentado na Figura 26. Todas as frações obtidas promoveram o acúmulo de fitoalexinas em mesocótilos de sorgo com ou sem tratamento prévio com abrasivo carborundum. Nenhuma das frações mostrou-se mais ativa que o extrato bruto. 
Na Figura 27 são mostrados os resultados da produção de fitoalexinas em mesocótilos de sorgo tratados com as frações provenientes da CTI com tampão bicarbonato de amônio (item 4.5). A fração I ocasionou a maior síntese de fitoalexinas, em mesocótilos sem tratamento prévio com abrasivo carborundum, mostrando-se mais ativa que as demais frações. As frações II, IV e $V$ não diferiram do controle negativo, sendo que a fração $V$ apresentou o menor acúmulo de fitoalexinas.

Em mesocótilos previamente tratados com carborundum, o tratamento controle negativo (água) promoveu alto acúmulo de fitoalexinas, enquanto que as frações IV, V, VII e $C$. sublineolum (controle positivo sem tratamento prévio com abrasivo carborundum) apresentaram os menores acúmulos destas fitoalexinas. 


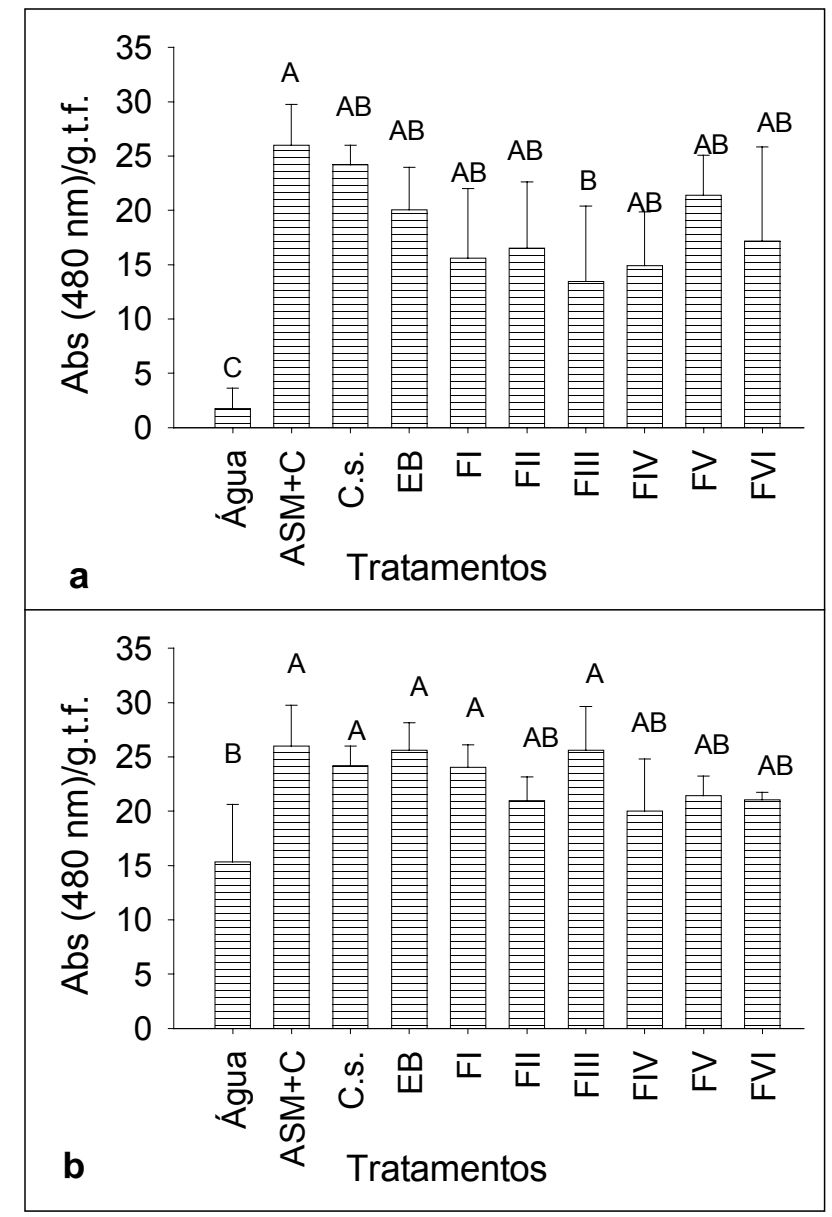

Figura 26 - Acúmulo de fitoalexinas em mesocótilos de sorgo após aspersão com as frações obtidas na cromatografia de troca iônica com tampão Tris-HCl; (a). Mesocótilos sem tratamento prévio; (b). Mesocótilos previamente tratados com abrasivo carborundum. C.s.Colletotrichum sublineolum: $1,5 \times 10^{5}$ esporos $/ \mathrm{mL}$. ASM+C: mesocótilos previamente tratados com abrasivo carborundum e com acibenzolar-S-metil (ASM) (50 ppm). EB: extrato bruto. Médias seguidas da mesma letra não são significativamente diferentes entre si (teste de Tukey $\mathrm{P}=0,01$ ). As barras representam o desvio padrão da média de 5 repetições. (a) $C V=30,7 \%$ e (b) $C V=14,4 \%$ 


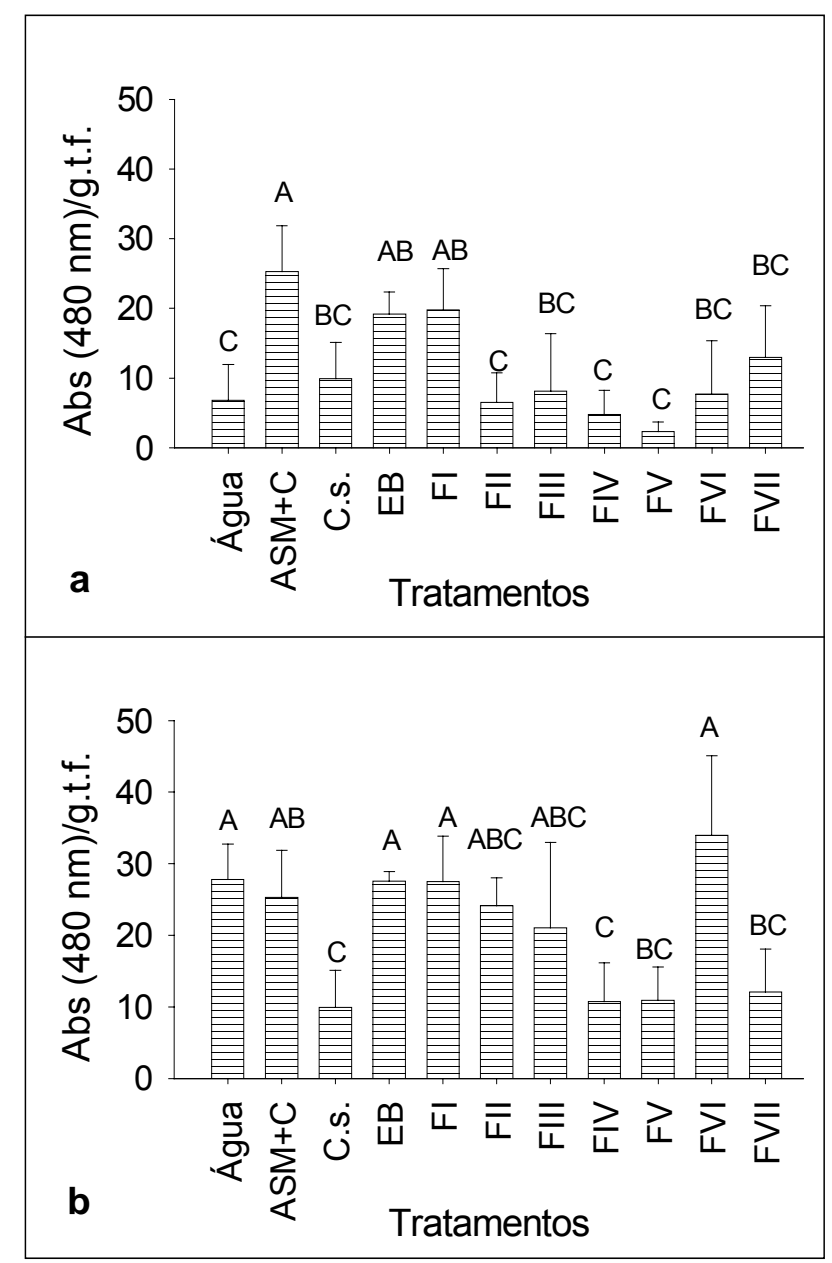

Figura 27 - Acúmulo de fitoalexinas em mesocótilos de sorgo após aspersão com as frações obtidas na cromatografia de troca iônica com tampão bicarbonato de amônio; (a). Mesocótilos sem tratamento prévio; (b). Mesocótilos previamente tratados com abrasivo carborundum. C.s.- Colletotrichum sublineolum: $1 \times 10^{5}$ esporos $/ \mathrm{mL}$. $\mathrm{ASM}+\mathrm{C}$ : mesocótilos previamente tratados com abrasivo carborundum e acibenzolar-S-metil (ASM) (50 ppm). EB: extrato bruto. Médias seguidas da mesma letra não são significativamente diferentes entre si (teste de Tukey $\mathrm{P}=0,01$ ). As barras representam o desvio padrão da média de 5 repetições. (a) $C V=50,6 \%$ e (b) $C V=32,3 \%$ 
Produção de fitoalexinas em folhas de sorgo

Nas plantas de sorgo que foram utilizadas no experimento de proteção de plantas de sorgo contra antracnose, foi possível observar o acúmulo de fitoalexinas nas folhas, em função da coloração vermelha presente nas mesmas. No primeiro experimento, quando plantas de sorgo, com 17 dias de idade foram tratadas com as frações provenientes da CTI com tampão Tris$\mathrm{HCl}$ (item 4.5), foi observado o acúmulo de fitoalexinas nas folhas tratadas com água, ASM, preparação de S. cerevisiae autoclavada por 4 horas seqüencialmente (extrato bruto) e com todas as frações (dados não mostrados). Nas folhas superiores (quinta folha) a produção de fitoalexinas foi observada somente quando as plantas haviam recebido as frações obtidas na CTI ou extrato bruto.

Plantas com 50 dias de idade produziram fitoalexinas nas folhas tratadas com as frações I, II, III, IV, VI e VII obtidas na CTI com tampão bicarbonato de amônio (item 4.5) e apenas a fração VI obtida na CTI com tampão Tris- $\mathrm{HCl}$ promoveu o acúmulo de fitoalexinas em folhas tratadas (dados não mostrados). Água e ASM não promoveram o acúmulo de fitoalexinas em folhas de sorgo nestas condições. Não foi observado o acúmulo de fitoalexinas nas folhas superiores a folha tratada.

A maior produção de fitoalexinas em folhas de sorgo foi observada quando as folhas foram tratadas com extrato bruto. Em ambos os experimentos o surgimento da coloração vermelha nas folhas ocorreu durante a manutenção das plantas em câmara úmida após a inoculação com o patógeno, cerca de 4 dias após o tratamento elicitor. $\mathrm{O}$ acúmulo de fitoalexinas pode ser observado nas folhas tratadas e nos caules das plantas de sorgo (Figura 28). 

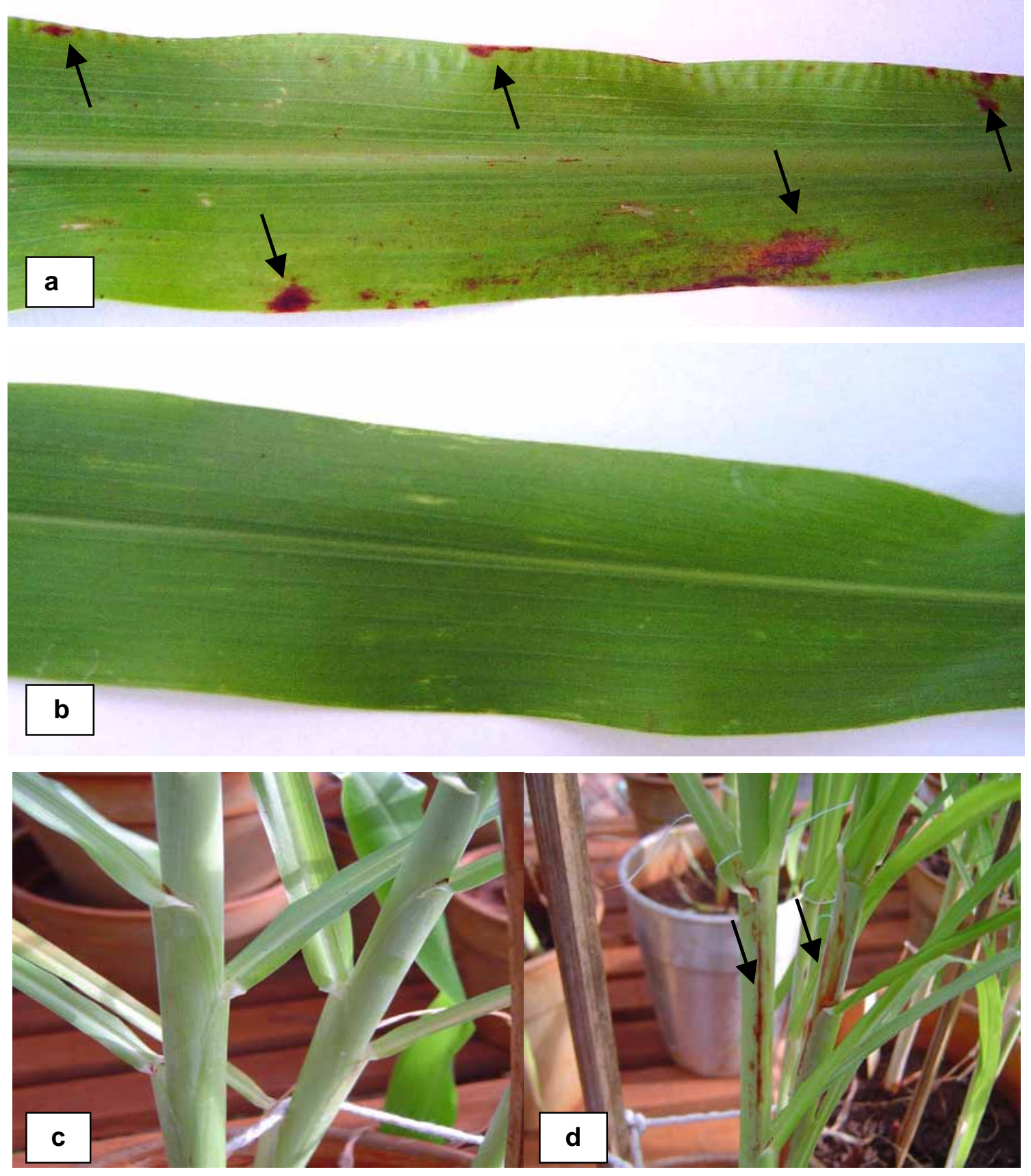

Figura 28 - Folhas de sorgo aos 5 dias do tratamento elicitor e 2 dias após inoculação do patógeno; (a). Extrato bruto; (b). Acibenzolar-Smetil. Caules de plantas de sorgo após 7 dias do tratamento elicitor e 4 dias após inoculação do patógeno; (c). Água; (d). Extrato bruto. Setas indicam o acúmulo de fitoalexinas (coloração avermelhada nas folhas e caule) 


\subsubsection{Germinação de esporos e formação de apressórios por fitopatógenos fúngicos}

Todas as frações obtidas na CTI com tampão Tris-HCl (item 4.5) promoveram estímulo da germinação de esporos por $C$. lagenarium. $\mathrm{Na}$ formação de apressórios houve estímulo pelas frações IV, $\mathrm{V}$ e $\mathrm{VI}$ e as demais frações não apresentaram diferença em relação ao controle (água). Enquanto que o extrato bruto estimulou a germinação de esporos, mas sem a formação de apressórios do patógeno (Figura 29). Por sua vez na germinação de esporos por $C$. sublineolum somente a fração I não promoveu estímulo da germinação não diferindo do controle (água) (Figura 30). Não houve efeito das frações testadas na formação de apressórios, enquanto que o extrato bruto favoreceu a germinação de esporos, mas sem formação de apressórios por $C$. sublineolum.

No teste com as frações obtidas por CTI, utilizando tampão bicarbonato de amônio (item 4.5), houve estímulo da germinação de esporos por C. lagenarium na presença das frações I e IV, inibição da germinação pelas frações V, VI e VII e as outras frações não apresentaram efeito estatisticamente significativo em relação ao controle (água) (Figura 31). Não houve formação de apressórios por $C$. lagenarium na fração I e todas as outras frações testadas inibiram a formação de apressórios. Por sua vez as frações I e II estimularam a germinação de esporos e a formação de apressórios por $C$. sublineolum e as frações III, IV, V, VI e VII apresentaram efeito inibitório na germinação de esporos e formação de apressórios (Figura 32). Houve efeito estimulador do extrato bruto na germinação de esporos por $C$. lagenarium e $C$. sublineolum sem a formação de apressórios (Figuras 31 e 32). 


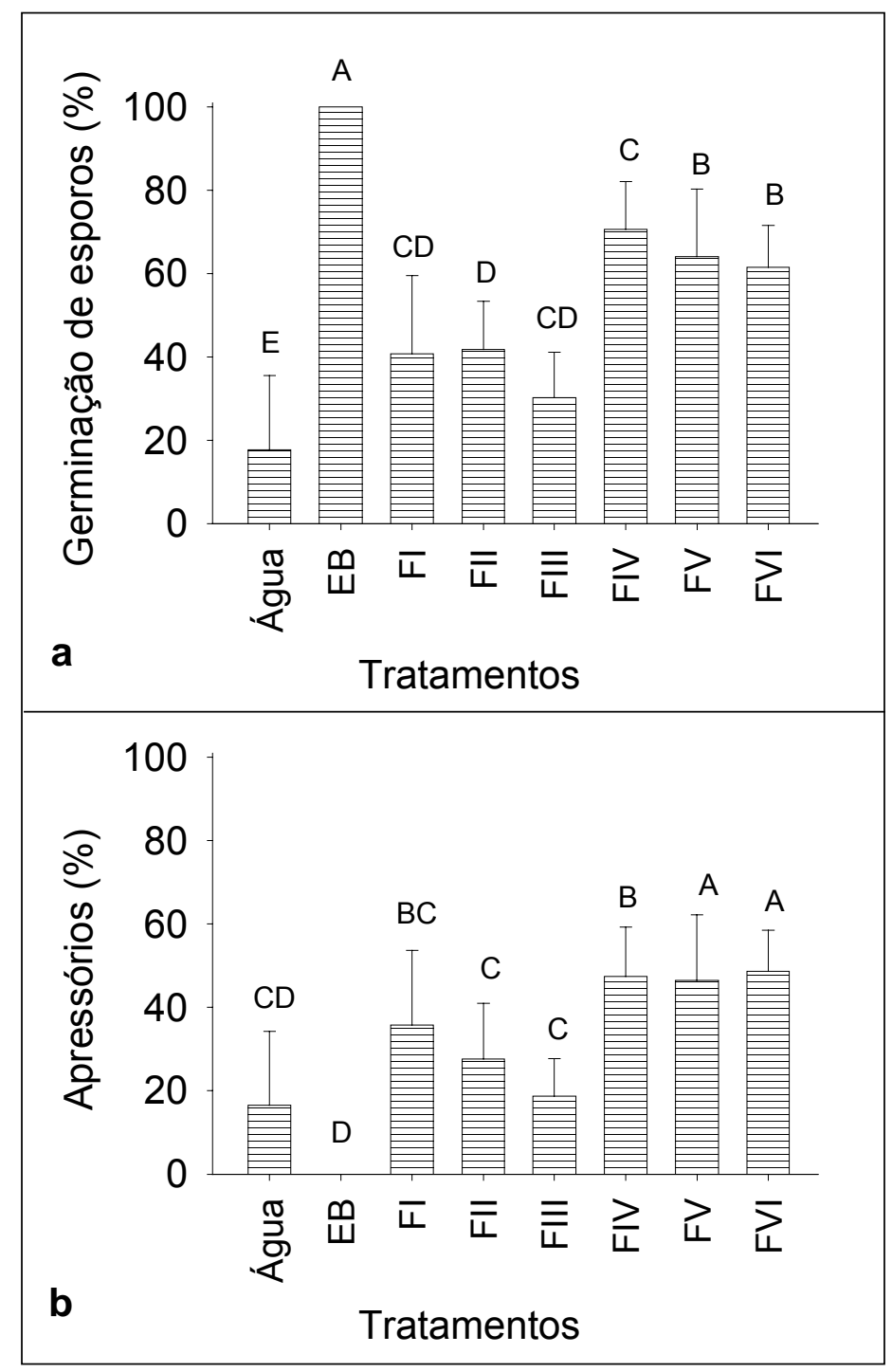

Figura 29 - Efeito das frações provenientes da cromatografia de troca iônica com tampão Tris- $\mathrm{HCl}$ na germinação de esporos e formação de apressórios por Colletotrichum lagenarium; (a). Germinação de esporos; (b). Formação de apressórios. Suspensão de esporos do patógeno: 1 x $10^{5}$ esporos $/ \mathrm{mL}$. EB: extrato bruto. Médias seguidas da mesma letra não são significativamente diferentes entre si (teste de Tukey $\mathrm{P}=0,01$ ). As barras representam o desvio padrão da média de 8 repetições. (a) CV= 24,4\% e (b) CV= 43,6\% 


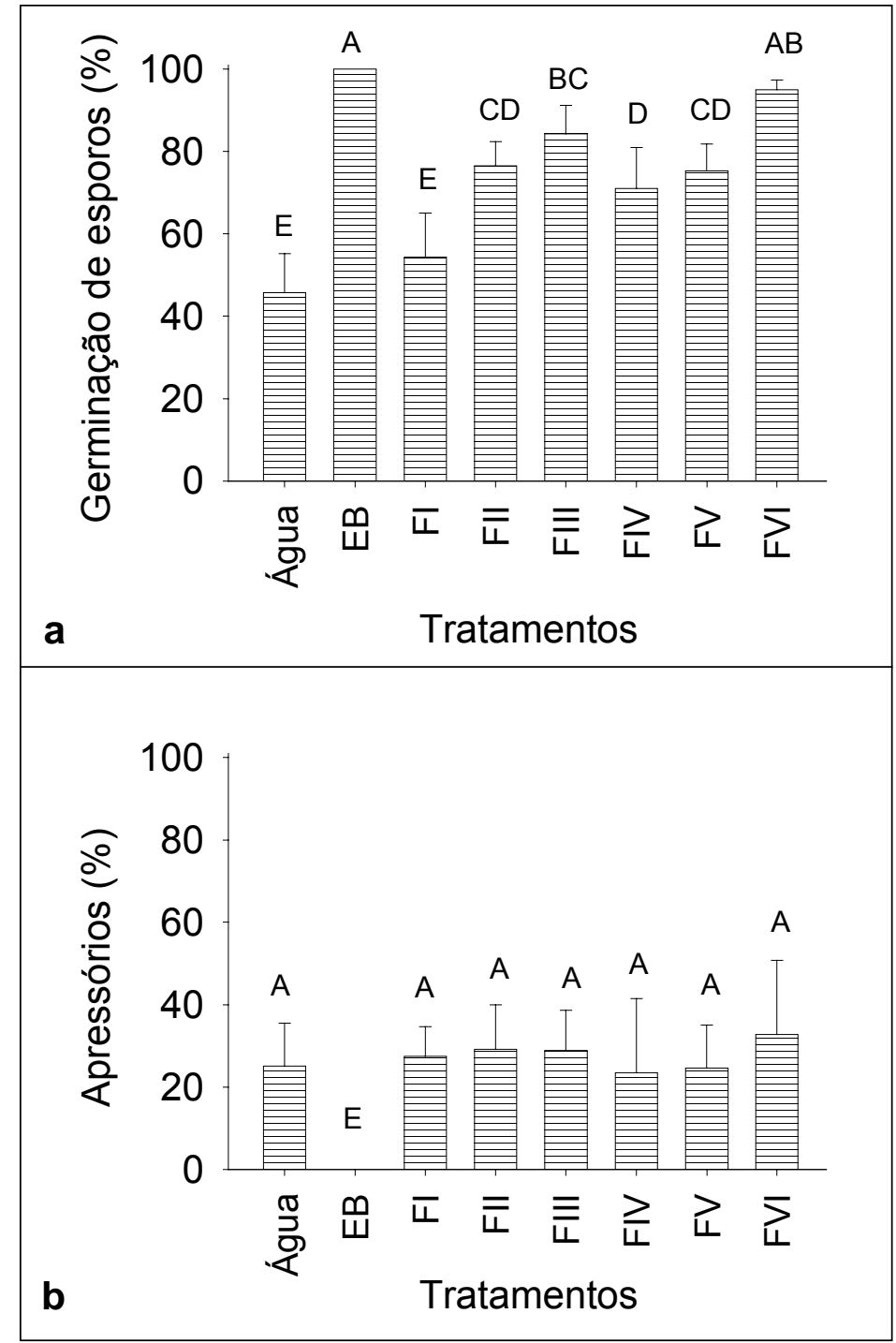

Figura 30 - Efeito das frações provenientes da cromatografia de troca iônica com tampão Tris- $\mathrm{HCl}$ na germinação de esporos e formação de apressórios por Colletotrichum sublineolum; (a). Germinação de esporos; (b). Formação de apressórios. Suspensão de esporos do patógeno: 1 × $10^{5}$ esporos $/ \mathrm{mL}$. EB: extrato bruto. Médias seguidas da mesma letra não são significativamente diferentes entre si (teste de Tukey $\mathrm{P}=0,01$ ). As barras representam o desvio padrão da média de 8 repetições. (a) $C V=9,8 \%$ e (b) $C V=49,4 \%$ 


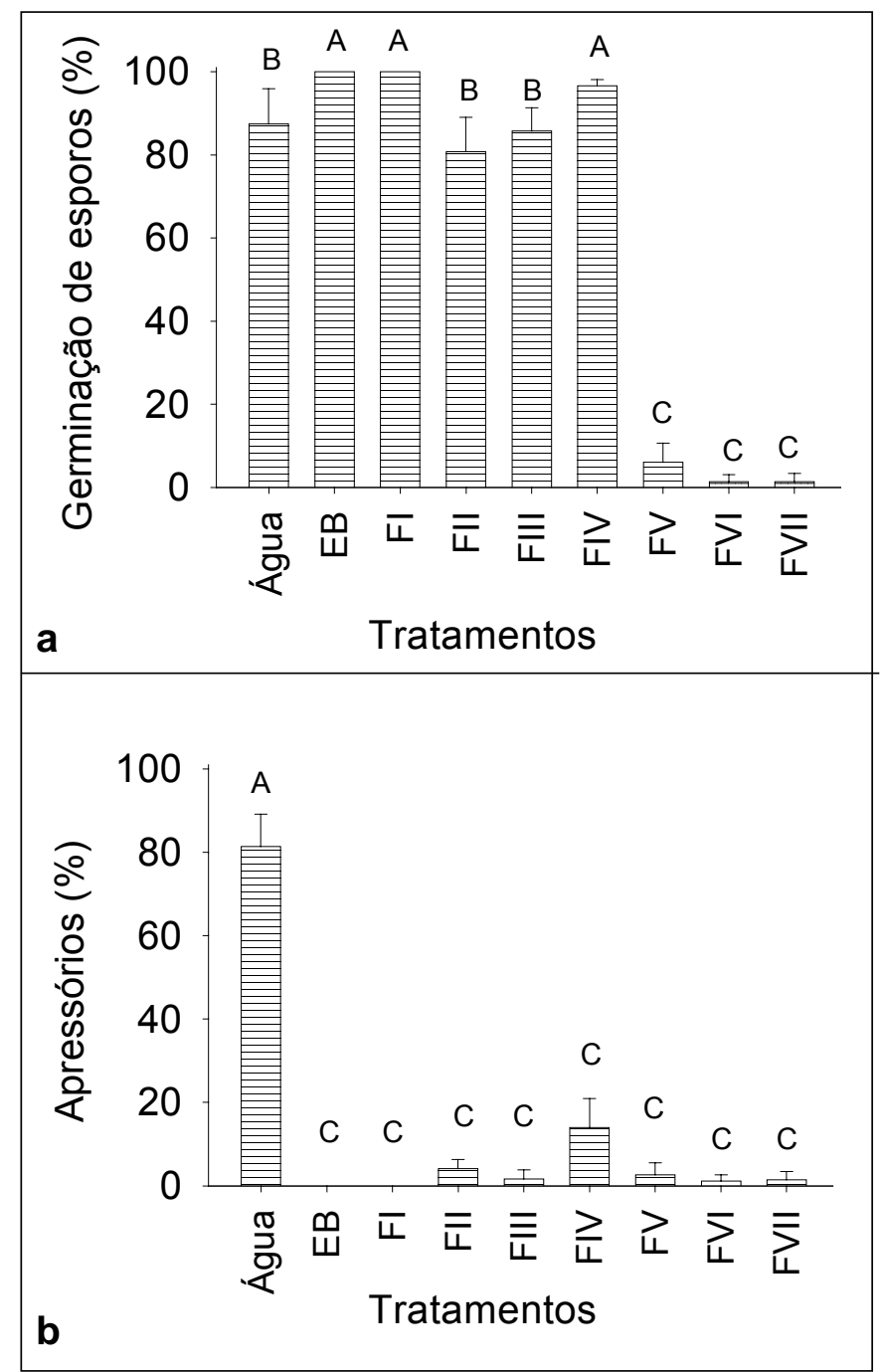

Figura 31 - Efeito das frações provenientes da cromatografia de troca iônica com tampão bicarbonato de amônio na germinação de esporos e formação de apressórios por Colletotrichum lagenarium; (a). Germinação de esporos; (b). Formação de apressórios. Suspensão de esporos do patógeno: 1 × $10^{5}$ esporos $/ \mathrm{mL}$. EB: extrato bruto. Médias seguidas da mesma letra não são significativamente diferentes entre si (teste de Tukey $P=0,01$ ). As barras representam o desvio padrão da média de 8 repetições. (a) $C V=7,7 \%$ e (b) $C V=32,84 \%$ 


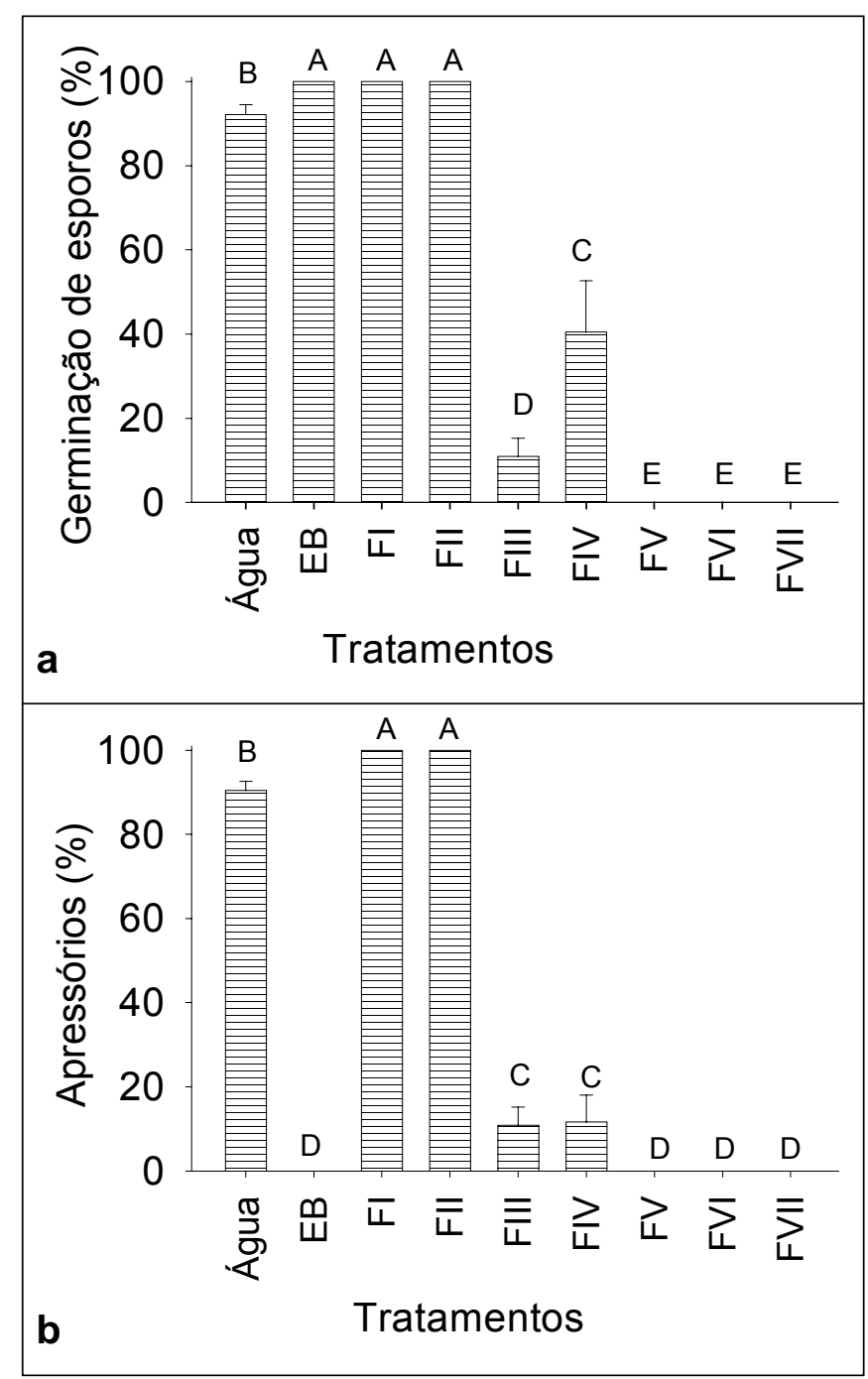

Figura 32 - Efeito das frações provenientes da cromatografia de troca iônica com tampão bicarbonato de amônio na germinação de esporos e formação de apressórios por Colletotrichum sublineolum; (a). Germinação de esporos; (b). Formação de apressórios. Suspensão de esporos do patógeno: 1 × $10^{5}$ esporos $/ \mathrm{mL}$. EB: extrato bruto. Médias seguidas da mesma letra não são significativamente diferentes entre si (teste de Tukey $\mathrm{P}=0,01$ ). As barras representam o desvio padrão da média de 8 repetições. (a) $C V=8,91 \%$ e (b) $\mathrm{CV}=7,7 \%$ 


\subsubsection{Proteção de plântulas de pepino a Colletotrichum lagenarium, em condições de câmara de crescimento e casa-de-vegetação, utilizando as frações obtidas nas CTIs}

\subsubsection{Proteção de plântulas de pepino em casa-de-vegetação e em câmara de crescimento com as frações provenientes da CTI utilizando tampão Tris- $\mathrm{HCl}$}

\section{Proteção de plântulas de pepino em câmara de crescimento}

Na proteção de plântulas de pepino em câmara de crescimento, foram realizados dois bioensaios, sendo que no primeiro as plântulas receberam o tratamento elicitor (item 4.5) dois dias antes da inoculação com o patógeno. Foi possível observar que a fração VI conferiu maior proteção enquanto que as plântulas tratadas com a fração II apresentaram a maior severidade (Figura 33). No segundo bioensaio, as plântulas receberam o tratamento elicitor 3 dias antes da inoculação com o patógeno. Nenhuma das frações testadas conferiu controle na manifestação da antracnose (Figura 34). O melhor controle da antracnose em plântulas de pepino, em ambos os experimentos, foi proporcionado por ASM.

\section{Proteção de plântulas de pepino em casa-de-vegetação}

No experimento realizado em casa-de-vegetação, plantas tratadas com as frações obtidas na cromatografia com tampão Tris- $\mathrm{HCl}$ (item 4.5) manifestaram sintomas um dia antes das plantas tratadas com água (controle negativo). Não houve diferença entre as frações e o controle negativo na manifestação dos sintomas da antracnose (Figura 35). O tratamento de plântulas de pepino com ASM levou a supressão completa dos sintomas da doença na época da avaliação. 


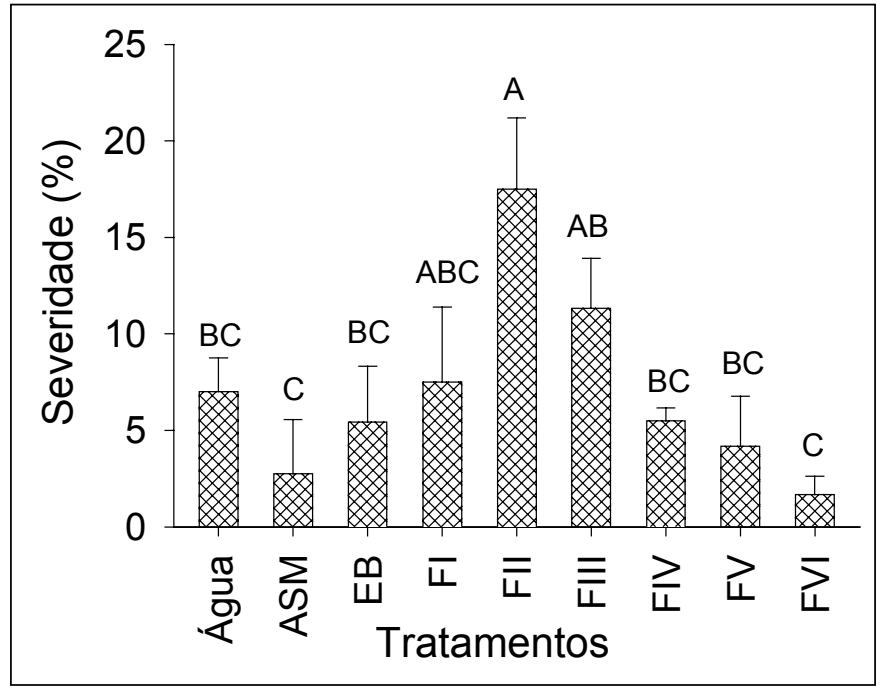

Figura 33 - Proteção de plântulas de pepino por frações provenientes da cromatografia de troca iônica, na manifestação de sintomas de antracnose. Plântulas com 5 dias de idade tiveram seus cotilédones tratados com água, acibenzolar-S-metil (ASM) (50 $\mathrm{ppm}$ ), extrato bruto (EB) ou com as frações da cromatografia de troca iônica com concentração de proteínas ajustada. Ao segundo dia após o tratamento elicitor, as plântulas foram inoculadas com suspensão de conídios de Colletotrichum lagenarium $\left(1 \times 10^{5}\right.$ esporos $/ \mathrm{mL}$ ). A severidade da doença foi quantificada 8 dias após a inoculação. Para efeito de análise estatística os dados foram transformados em raiz de $x+0,5$. Médias seguidas da mesma letra não são significativamente diferentes entre si (teste de Tukey $\mathrm{P}=0,01$ ). As colunas representam as médias, enquanto as barras, o desvio padrão da média de 3 repetições. CV $=20,02 \%$ 


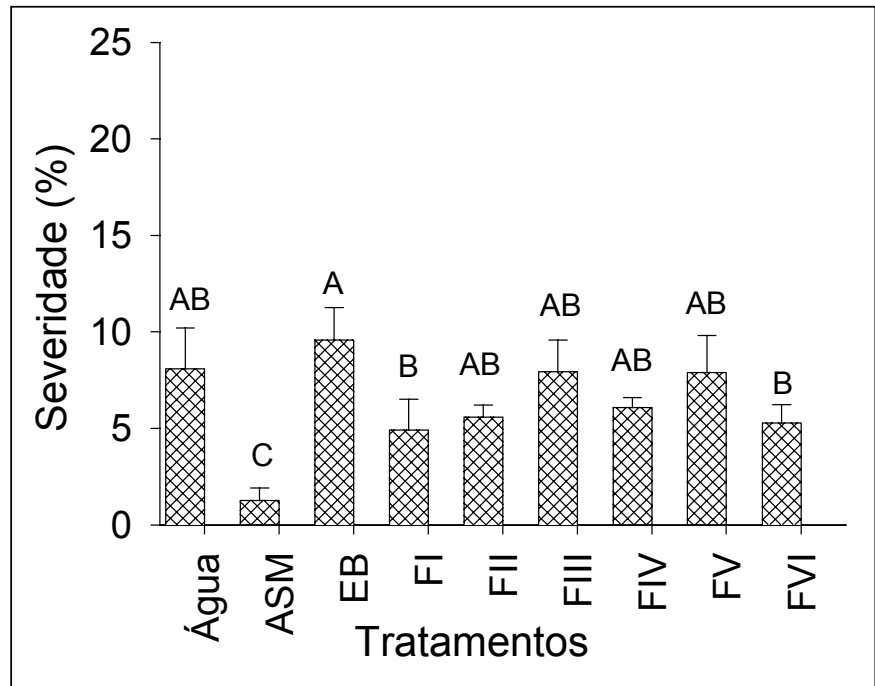

Figura 34 - Proteção de plântulas de pepino por frações provenientes da cromatografia de troca iônica, na manifestação de sintomas de antracnose. Plântulas com 6 dias de idade tiveram seus cotilédones tratados com água, acibenzolar-S-metil (ASM) (50 ppm), extrato bruto (EB) ou com as frações da cromatografia de troca iônica com concentração de proteínas ajustada. Ao terceiro dia após o tratamento elicitor, as plântulas foram inoculadas com suspensão de conídios de Colletotrichum lagenarium $\left(1,25 \times 10^{5}\right.$ esporos $/ \mathrm{mL}$ ). A severidade da doença foi quantificada 6 dias após a inoculação. Para efeito de análise estatística os dados foram transformados em raiz de $x+0,5$. Médias seguidas da mesma letra não são significativamente diferentes entre si (teste de Tukey $P=0,01)$. As colunas representam as médias, enquanto as barras, o desvio padrão da média de 3 repetições. CV $=10,40 \%$ 


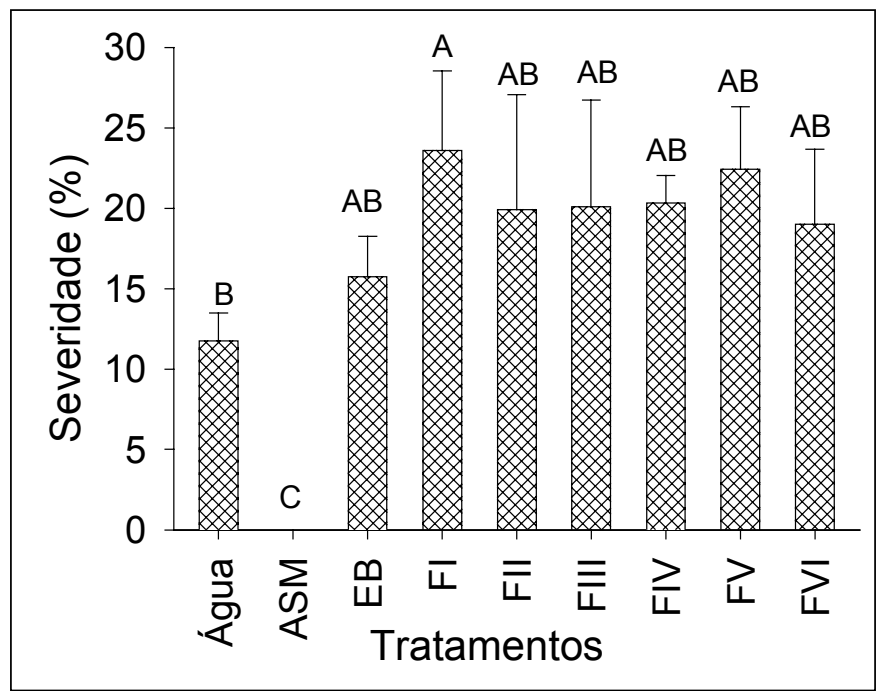

Figura 35 - Proteção de plântulas de pepino por frações provenientes da cromatografia de troca iônica, na manifestação de sintomas de antracnose. Plântulas com 5 dias de idade tiveram seus cotilédones tratados com água, acibenzolar-S-metil (ASM) (50 ppm), extrato bruto (EB) ou com as frações da cromatografia de troca iônica com concentração de proteínas ajustada. Ao terceiro dia após o tratamento elicitor, as plântulas foram inoculadas com suspensão de conídios de Colletotrichum lagenarium $\left(1 \times 10^{5}\right.$ esporos $/ \mathrm{mL}$ ). A severidade da doença foi quantificada 6 dias após a inoculação. Para efeito de análise estatística os dados foram transformados em raiz de $x+0,5$. Médias seguidas da mesma letra não são significativamente diferentes entre si (teste de Tukey $P=0,01)$. As colunas representam as médias, enquanto as barras, o desvio padrão da média de 3 repetições. $C V=11,96 \%$ 


\subsubsection{Proteção de plântulas de pepino em casa-de-vegetação com as frações provenientes da CTI utilizando tampão bicarbonato de amônio}

Não houve diferença estatisticamente significativa entre as frações na proteção de plântulas de pepino (Figura 36). Porém, observa-se que nas plântulas de pepino tratadas com a fração III (item 4.5) e com extrato bruto houve uma redução na severidade da doença em relação ao controle negativo (água).

As frações II, III e VII apresentaram efeito fitotóxico nas plântulas de pepino 48 horas após o tratamento elicitor, quando as bordas dos cotilédones tratados apresentaram coloração branca (Figura 37). Para verificar se o efeito de fitotoxidez observado ocorria em função do material proveniente da preparação de S. cerevisiae ou do tampão utilizado na CTI, plântulas de pepino mantidas nas mesmas condições das plântulas utilizadas no bioensaio de proteção, foram tratadas com tampão bicarbonato de amônio nas mesmas condutividades das frações que promoveram ou não a fitotoxidez. As frações que promoveram fitotoxidez apresentaram as seguintes condutividades: fração II: 9,0 mS, fração III: $5,5 \mathrm{mS}$ e fração VII: $29,0 \mathrm{mS}$. Após 7 dias do tratamento dos cotilédones com tampão bicarbonato de amônio, em diferentes condutividades, nenhuma alteração na coloração dos mesmos foi observada (Figura 38). 


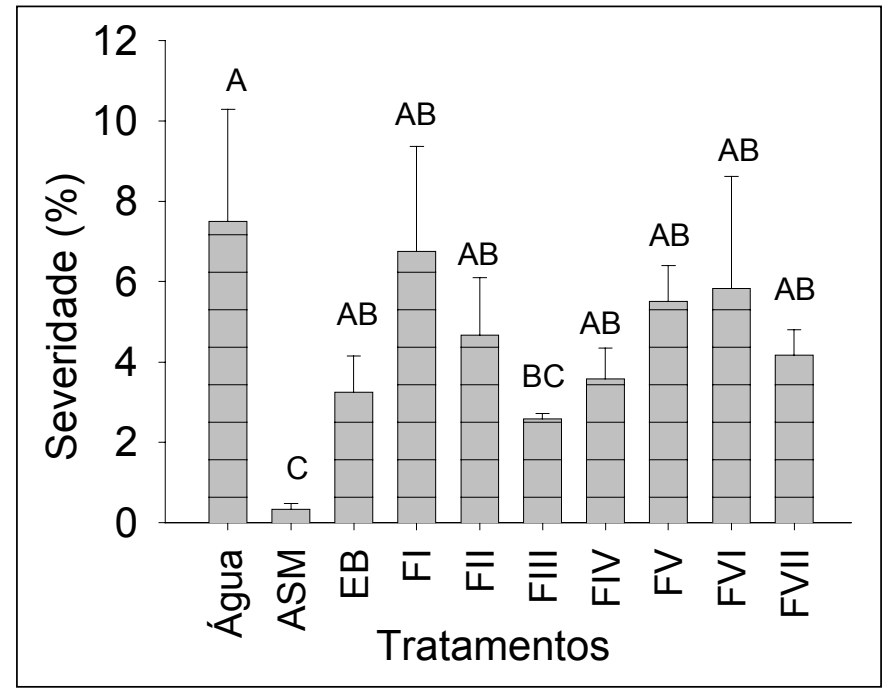

Figura 36 - Proteção de plântulas de pepino por frações provenientes da cromatografia de troca iônica, na manifestação de sintomas de antracnose. Plântulas com 5 dias de idade tiveram seus cotilédones tratados com água, acibenzolar-S-metil (ASM) (50 $\mathrm{ppm}$ ), extrato bruto (EB) ou com as frações da cromatografia de troca iônica com concentração de proteínas ajustada. Ao terceiro dia após o tratamento elicitor, as plântulas foram inoculadas com suspensão de conídios de Colletotrichum lagenarium $\left(1 \times 10^{5}\right.$ esporos $/ \mathrm{mL}$ ). A severidade da doença foi quantificada 5 dias após a inoculação. Para efeito de análise estatística os dados foram transformados em raiz de $x+0,5$. Médias seguidas da mesma letra não são significativamente diferentes entre si (teste de Tukey $\mathrm{P}=0,01)$. As colunas representam as médias, enquanto as barras, o desvio padrão da média de 3 repetições. $C V=14,9 \%$ 


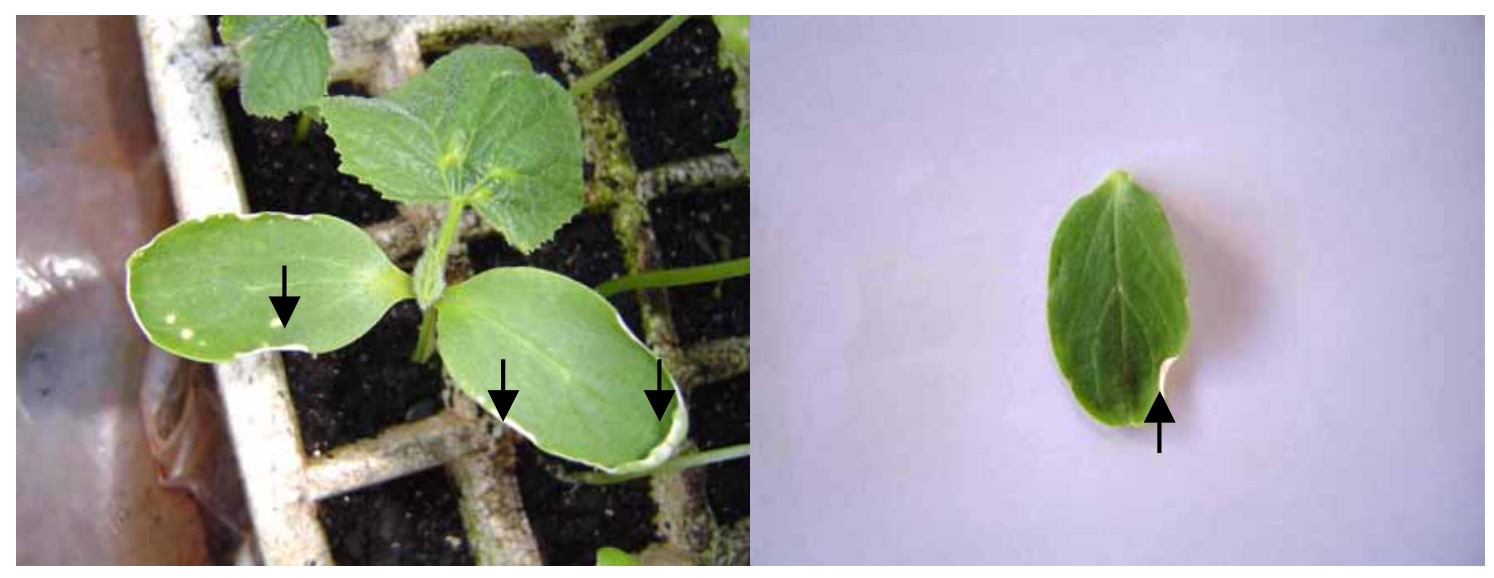

Figura 37 - Cotilédones de pepino apresentando sintomas de fitotoxidez (setas) após 48 horas do tratamento com a Fração III obtida da cromatografia com tampão bicarbonato de amônio
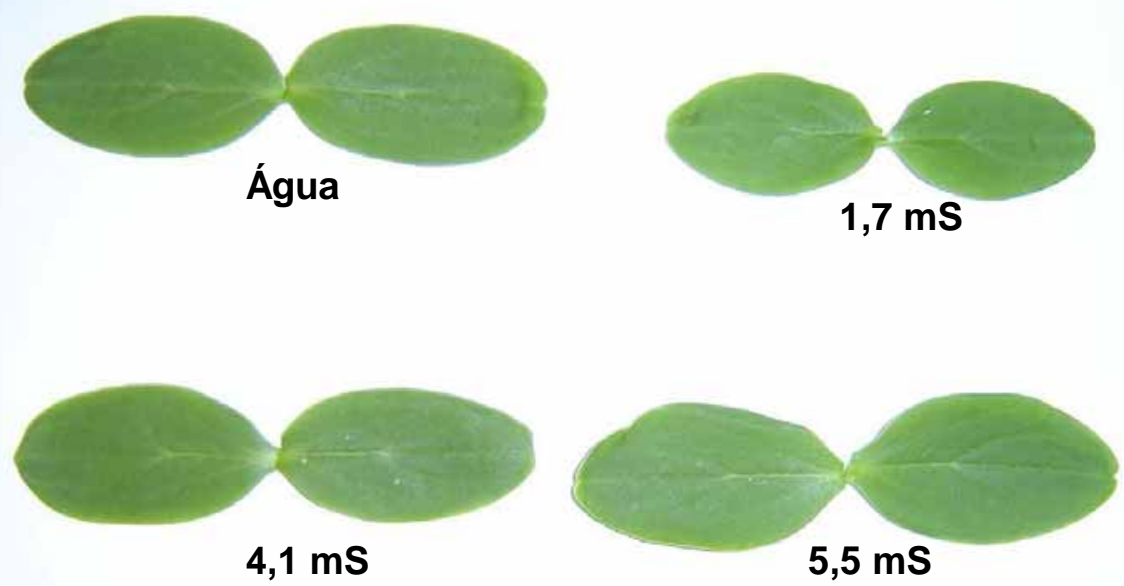

$4,1 \mathrm{mS}$

$5,5 \mathrm{mS}$
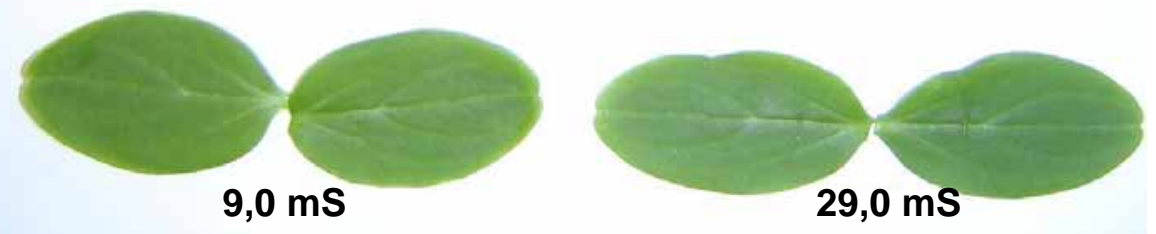

Figura 38 - Cotilédones de pepino após 6 dias do tratamento com água e tampão bicarbonato de amônio em diferentes condutividades 


\subsubsection{Atividade de peroxidases}

Para análise da atividade de peroxidases, plântulas de pepino mantidas em casa-de-vegetação foram tratadas com as frações obtidas nas CTIs (item 4.5) e inoculadas com $C$. lagenarium. A análise bioquímica só foi realizada para os tratamentos que conferiram proteção das plântulas de pepino a antracnose nos experimentos realizados em casa-de-vegetação. Como no primeiro experimento não houve proteção pelas frações obtidas na CTI com tampão Tris- $\mathrm{HCl}$, a análise de peroxidases foi realizada somente quando os cotilédones foram tratados com água, extrato bruto e ASM. A atividade de peroxidases foi maior aos 6 dias em cotilédones tratados com ASM (Figura 39a). Não houve diferença entre os demais tratamentos, mesmo após 6 dias do tratamento elicitor.

No segundo experimento, cotilédones tratados com a fração III proveniente da CTI com tampão bicarbonato de amônio, apresentaram redução da severidade da doença e por isto, foi realizada a análise de peroxidases de cotilédones que receberam este tratamento. Cotilédones tratados com ASM apresentaram a maior atividade de peroxidases aos 3 e 6 dias após o tratamento elicitor. Quando os cotilédones de pepino foram tratados com a fração III houve aumento da atividade da peroxidases após 6 dias do tratamento elicitor (Figura 39b). 


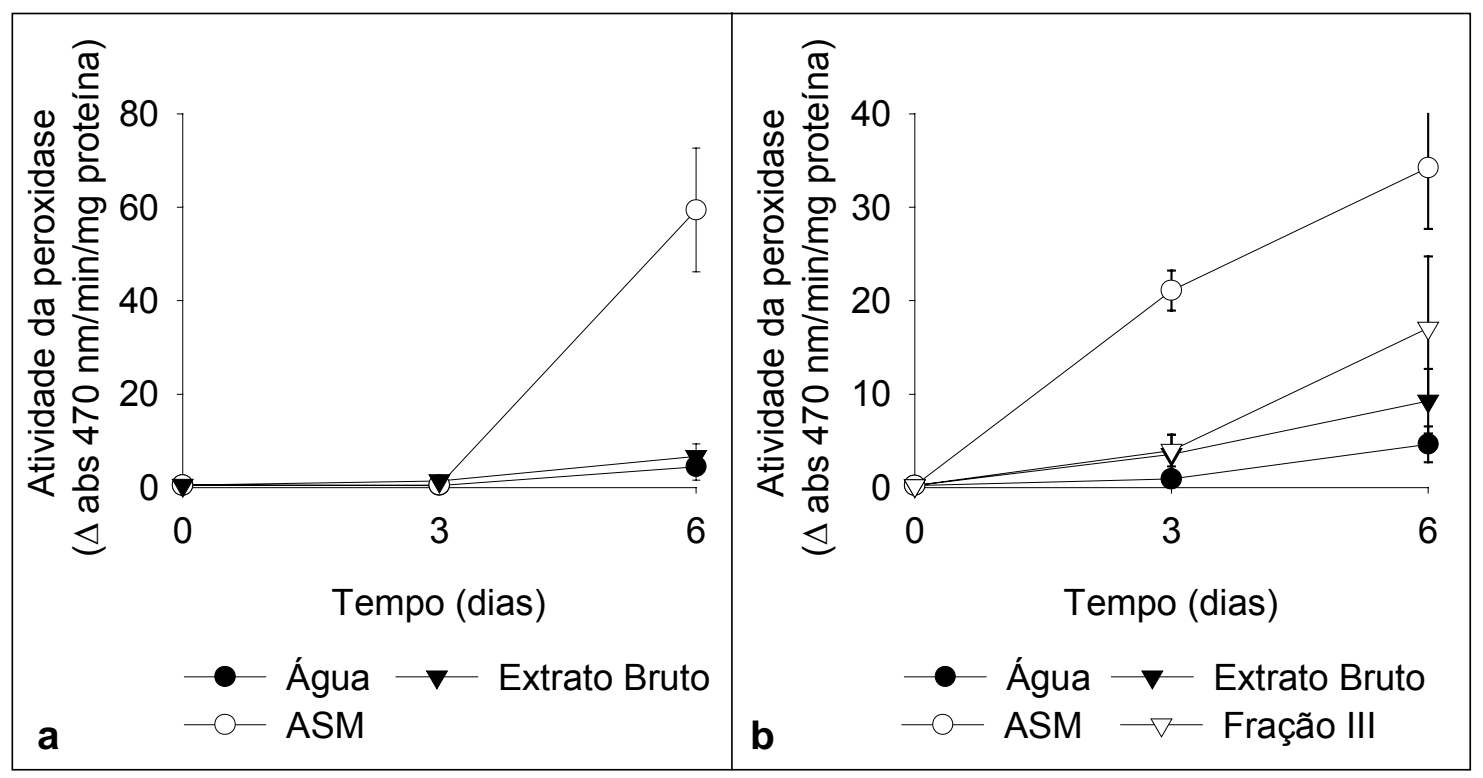

Figura 39 - Atividade de peroxidases em cotilédones de pepino resultante de tratamento elicitor; (a). Primeiro experimento; (b). Segundo experimento. Plântulas de pepino tratadas com água, extrato bruto, acibenzolar-S-metil (ASM) (50 ppm) ou fração III da CTI com tampão bicarbonato de amônio e após 3 dias inoculadas com Colletotrichum lagenarium. Amostras para análise da enzima foram retiradas imediatamente antes do tratamento (T0); 3 dias após o tratamento elicitor (imediatamente antes da inoculação, T3) e 3 dias após a inoculação (6 dias após o tratamento elicitor, T6). As barras representam \pm 0 desvio padrão da média de 3 repetições 


\title{
4.5.5 Proteção de plantas de sorgo a Colletotrichum sublineolum em casa- de-vegetação utilizando as frações obtidas nas CTIs
}

\author{
Proteção de plantas de sorgo por frações obtidas na CTI com \\ $\underline{\text { tampão Tris-HCl }}$
}

Com relação à proteção local, o extrato bruto e as frações III, IV, V e VI (item 4.5) foram capazes de reduzir a severidade da doença quando comparadas com o controle negativo (água). Folhas tratadas com a fração I apresentaram a maior severidade doença, enquanto que ASM conferiu a melhor proteção (Figura 40a). Na avaliação das folhas superiores (proteção sistêmica), observa-se na Figura 40b que o extrato bruto, ASM e as frações IV, V e VI conferiram redução na severidade da doença.

Proteção de plantas de sorgo por frações obtidas na CTI com tampão bicarbonato de amônio

$\mathrm{Na}$ proteção local e sistêmica de folhas de sorgo somente as folhas que receberam ASM apresentaram diferença estatisticamente significativa em relação ao controle negativo (água) (Figura 41). Porém, com relação à proteção local, folhas tratadas com o extrato bruto e com a fração I apresentaram uma redução da severidade da doença de 14 e $15 \%$ respectivamente, apesar dos dados não apresentarem diferença estatisticamente significativa (Figura 41a).

Na proteção sistêmica não houve diferença significativa entre as frações, extrato bruto e o controle negativo na manifestação dos sintomas. Porém, é possível observar que as frações I, II, III, IV e VI e o extrato bruto foram capazes de reduzir a severidade de antracnose quando comparadas com o controle negativo (Figura 41b). 


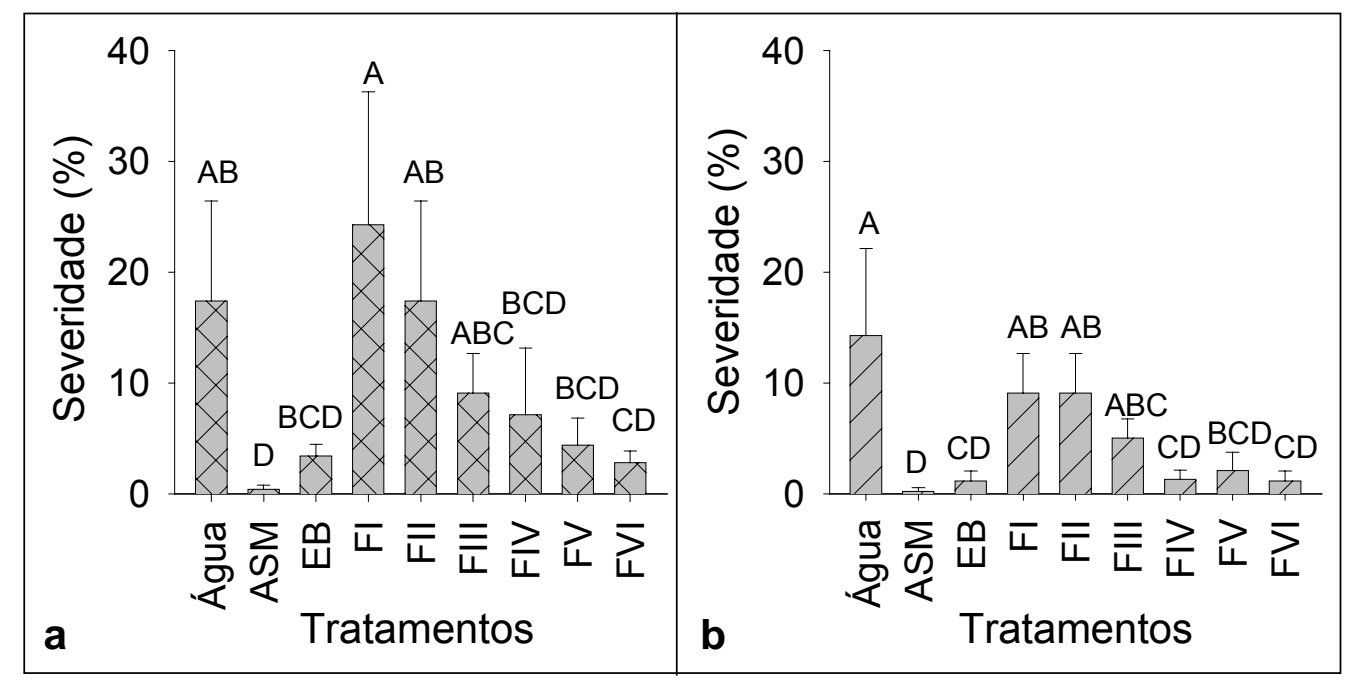

Figura 40 - Proteção de plântulas de sorgo por frações provenientes da cromatografia de troca iônica com tampão Tris- $\mathrm{HCl}$, na manifestação de sintomas de antracnose; (a). Severidade na folha tratada; (b). Severidade na folha superior. Plântulas com 50 dias de idade tiveram a quarta folha tratada com água, acibenzolar-S-metil (ASM) (50 ppm), extrato bruto (EB) ou com as frações da cromatografia de troca iônica com concentração de proteínas ajustada. Ao terceiro dia após tratamento elicitor as plântulas foram inoculadas com suspensão de conídios de Colletotrichum sublineolum $\left(1,25 \times 10^{5}\right.$ esporos $\left./ \mathrm{mL}\right)$. A severidade da doença foi quantificada 7 dias após a inoculação. Para efeito de análise estatística os dados foram transformados em raiz de $\mathrm{x}$ + 0,5. Médias seguidas da mesma letra não são significativamente diferentes entre si (teste de Tukey $\mathrm{P}=0,01$ ). As colunas representam as médias, enquanto as barras, o desvio padrão da média de 3 repetições; (a). CV = 30,3\%; (b). CV= $30,6 \%$ 


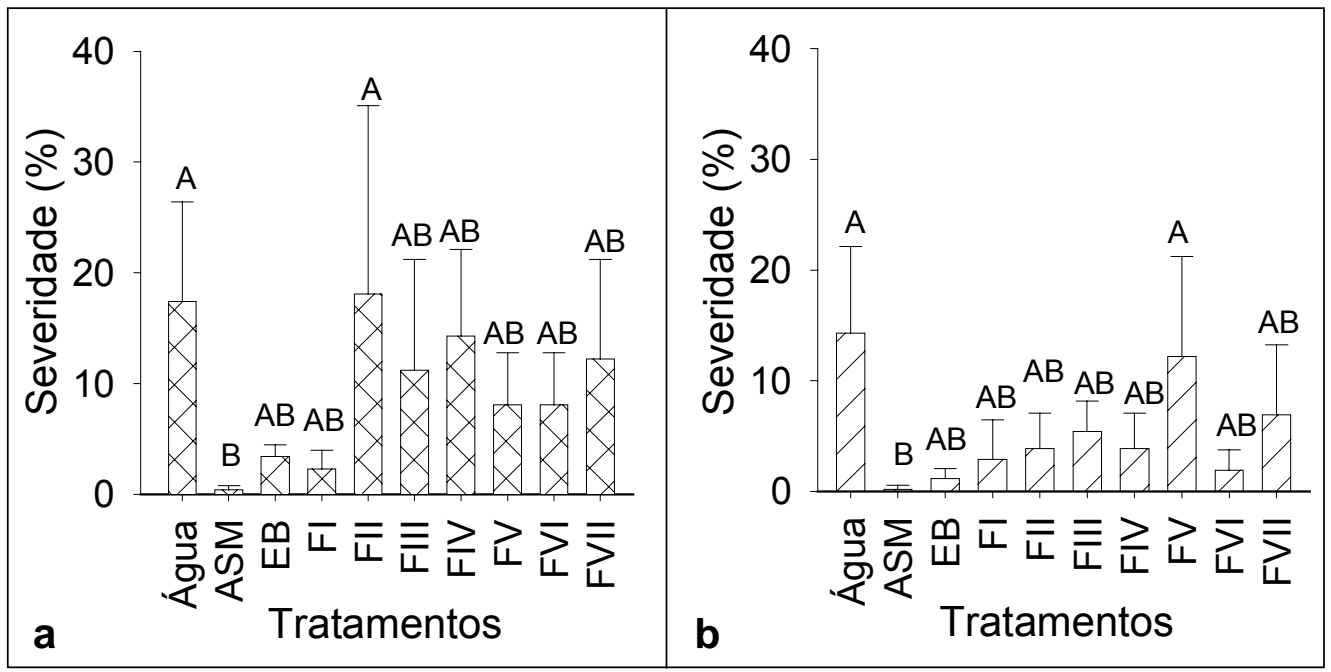

Figura 41 - Proteção de plântulas de sorgo por frações provenientes da cromatografia de troca iônica com tampão bicarbonato de amônio, na manifestação de sintomas de antracnose; (a). Severidade na folha tratada; (b). Severidade na folha superior. Plântulas com 50 dias de idade tiveram a quarta folha tratada com água, acibenzolar-S-metil (ASM) (50 ppm), extrato bruto (EB) ou com as frações da cromatografia de troca iônica com concentração de proteínas ajustada. Ao terceiro dia após tratamento elicitor as plântulas foram inoculadas com suspensão de conídios de Colletotrichum sublineolum $\left(1,25 \times 10^{5}\right.$ esporos $(\mathrm{mL})$. A severidade da doença foi quantificada 7 dias após a inoculação. Para efeito de análise estatística os dados foram transformados em raiz de $x+0,5$. Médias seguidas da mesma letra não são significativamente diferentes entre si (teste de Tukey $P=0,01)$. As colunas representam as médias, enquanto as barras, o desvio padrão da média de 3 repetições; (a). CV = $40,6 \%$; (b). CV $=48,5 \%$ 


\section{DISCUSSÃO}

$\mathrm{Na}$ literatura encontram-se diversos exemplos de elicitores de defesa em plantas purificados a partir de microrganismos, como por exemplo: a proteína purificada de filtrados de cultura de $P$. boehmeriae, que promove reação de hipersensibilidade em folhas de fumo e indução de resistência sistêmica ao vírus TMV, Alternaria alternata, $P$. parasitica e Ralstonia solanacearum (Wang et al., 2003); a oligandrina, uma elicitina produzida por Pythium oligandrum que induz resistência sistêmica a Fusarium oxysporum $\mathrm{f}$. sp. radicis-lycopersici em plantas de tomate (Benhamou et al., 2001); a glucana da parede celular de $P$. sojae que promove o acúmulo de fitoalexinas do tipo gliceolina em cotilédones de soja (Abbasi et al., 2001); a glicoproteína purificada a partir do filtrado de cultura de Verticillium dahliae que induz o acúmulo de fitoalexinas em células de algodão (Davis et al., 1998); o elicitor glicoprotéico purificado a partir de $P$. megasperma f. sp. glycinea que proporciona indução de respostas de defesa como fitoalexinas em células de salsa (Nürnberger et al., 1994) e a glicoproteína purificada a partir do patógeno $P$. oryzae que induz respostas de defesa em arroz (Schaffrath et al., 1995).

O presente trabalho foi baseado nas hipóteses propostas por Wulff (1997) e Labanca (2002) que relataram a presença de molécula (s) elicitora (s) na parede celular de $S$. cerevisiae, sendo que as frações ativas apresentavam proteínas e carboidratos. Labanca (2002), entretanto, relatou um baixo rendimento durante o processo de purificação da (s) molécula (s) elicitora (s). Segundo Hahn (1996) o baixo rendimento no processo de purificação é apontado como um fator que restringe o estudo de respostas gerais de defesa 
ou de sinalização, levando a maior parte dos trabalhos a serem realizados usando respostas específicas de defesa, como o acúmulo de fitoalexinas em tecidos vegetais, para nortear a purificação (Labanca, 2002; Wulff \& Pascholati, 1999; Davis et al., 1998; Guzzo, 1989; Hahn \& Albersheim, 1978). Assim, a metodologia de extração do elicitor da levedura S. cerevisiae e algumas etapas do processo de purificação foram adaptadas objetivando sempre um maior rendimento da (s) molécula (s) elicitora (s) que possibilitassem a realização dos bioensaios propostos.

\subsection{Extração do elicitor presente na parede celular de Saccharomyces cerevisiae}

Segundo Wulff (1997) estudos que objetivam a caracterização da natureza química e a estrutura dos elicitores, requerem que quantidades razoáveis destas moléculas estejam disponíveis em grau máximo de pureza. A autoclavagem é o processo utilizado para a extração de elicitores da parede celular de S. cerevisiae (Labanca, 2002; Wulff, 1997). Este último autor relatou que a eficiência da extração do elicitor por autoclavagem foi considerada boa, pois a atividade elicitora ficou restrita ao filtrado das células autoclavadas. Neste mesmo trabalho o autor relata que, além das moléculas elicitoras serem termoestáveis, a autoclavagem é um método simples de solubilização das moléculas de interesse a partir das células de levedura. Porém, no procedimento adotado por Labanca (2002) e Wulff (1997), inicialmente descrito por Roveratti (1989), não foi estudado um tempo de autoclavagem que promovesse maior solubilização da (s) molécula (s) elicitora (s). Em função do baixo rendimento do processo de purificação relatado por Labanca (2002) e da autoclavagem extrair a (s) molécula (s) elicitora (as) presente (s) na parede celular de S. cerevisiae, surgiu à hipótese desta extração ser maior em função 
do aumento do tempo de autoclavagem, o que permitiria iniciar o processo de purificação com maior conteúdo da (s) molécula (s) elicitora (as).

$\mathrm{Na}$ realização da curva de autoclavagem para extração do elicitor presente na parede celular de S. cerevisiae foi observado inicialmente aumento do conteúdo de carboidratos nas preparações de levedura em função da autoclavagem e do aumento do tempo de autoclavagem. Quando empregado a autoclavagem em seqüência (inicialmente realizada em minutos), observou-se que as preparações provenientes desta autoclavagem apresentaram um maior conteúdo de carboidratos do que preparações autoclavadas uma única vez (Figura 6). Preparações de levedura submetidas a autoclavagem em seqüência foram autoclavadas por um tempo maior que as preparações autoclavadas apenas uma vez. Nova hipótese surgiu após a realização desta etapa inicial, o maior conteúdo de carboidratos nas preparações autoclavadas seqüencialmente estava relacionado ao maior tempo de autoclavagem, ou estava relacionado ao processo de aquecimento e resfriamento aos quais estas preparações foram submetidas. Para elucidar esta hipótese preparações de $S$. cerevisiae foram então submetidas a autoclavagem por períodos de tempo maiores (horas), uma única vez ou seqüencialmente. Os resultados mostraram que o maior conteúdo de carboidratos das preparações estava relacionada ao processo de aquecimento e resfriamento das mesmas, uma vez que novamente em horas o conteúdo de carboidratos foi maior nas preparações autoclavadas seqüencialmente (Figura 6). O processo de autoclavagem seqüencial promove então maior extração dos carboidratos da parede celular da levedura, levando provavelmente a uma maior extração da (s) molécula (s) elicitora (s).

Com relação ao conteúdo de proteínas das preparações de $S$. cerevisiae, não houve aumento em função do tempo de autoclavagem, mesmo nas preparações autoclavadas seqüencialmente. A autoclavagem promoveu aumento do conteúdo de proteínas apenas em relação ao tempo zero de autoclavagem (Figura 7). O conteúdo de carboidratos nas preparações foi sempre maior que o conteúdo de proteínas das mesmas (Figura 8), o que esta 
de acordo com o relatado por Lopez (1991), que observou na fração do filtrado que apresentava atividade protetora em sorgo contra $C$. sublineolum uma proporção de $72 \%$ de carboidratos para $28 \%$ de proteínas.

Segundo Cabib et al. (1982), é possível extrair mananas da parede da levedura por autoclavagem, sendo que as glucanas e a quitina são mais resistentes à extração. As glucanas são extraídas por tratamento com álcali e ácido a quente, entretanto não se pode descartar a possibilidade de que alguma porção do polissacarídeo tenha sido extraída juntamente com as mananas (Labanca, 2002). Alguns autores criticam a autoclavagem para a obtenção de elicitores por representar um tratamento drástico para proteínas, causando desnaturação e podendo afetar os polímeros de manose (Nakajima \& Ballou, 1974), porém para avaliar a ocorrência de alterações nas preparações de levedura seria necessário realizar a purificação de moléculas elicitoras a partir de células sem tratamento térmico (Wulff, 1997).

As preparações elicitoras utilizadas nos bioensaios envolvendo a síntese de fitoalexinas em mesocótilos de sorgo e na germinação de esporos e formação de apressórios por fitopatógenos fúngicos, foram uniformizadas tendo como base a concentração de carboidratos da preparação não autoclavada (tempo 0). A escolha de carboidratos e não de proteínas foi baseada na possibilidade de ser um carboidrato o elicitor de fitoalexinas em soja, com capacidade de induzir resistência em plantas de pepino (Labanca, 2002). Entretanto, nesta primeira etapa do processo de purificação, não foi possível separar preparações de S. cerevisiae mais ativas na síntese de fitoalexinas em mesocótilos de sorgo e todas as preparações apresentaram efeito estimulador da germinação de esporos dos fitopatógenos. Para prosseguir no processo de purificação a preparação de levedura autoclavada por 4 horas seqüencialmente foi escolhida para a etapa de separação por CTI, principalmente por apresentar maior conteúdo de carboidratos, podendo ser um indicativo de que nesta preparação o conteúdo da (s) molécula (s) elicitora (s) estivesse presente em concentrações mais altas do que nas demais preparações de S. cerevisiae. 
Portanto, por considerar a presença de mais de um elicitor na parede celular de $S$. cerevisiae, sendo que pelo menos um destes compostos é um carboidrato como relatado por Labanca (2002), e objetivando maior rendimento deste elicitor, a etapa da precipitação etanólica foi omitida. A preparação foi então submetida à liofilização para concentração do material a ser usado na CTI. A cromatografia de troca iônica é uma das etapas freqüentemente empregada na purificação de elicitores (Wang et al., 2003; Labanca, 2002; Benhamou et al., 2001; Wulff, 1997; Guzzo, 1989). Na aplicação da amostra foram empregados dois tampões para eluição da coluna, sendo que ambos permitiram a separação de frações mais ativas das frações menos ativas. Em CTI realizada com tampão bicarbonato de amônio foram obtidas sete frações, sendo que o extrato bruto aplicado e as frações obtidas apresentaram coloração conforme apresentando na Figura 25. Neste caso, as frações obtidas na CTI não foram submetidas à diálise, processo este que retira pigmentos das amostras.

Com relação à atividade elicitora das frações, nas cromatografias com tampão Tris- $\mathrm{HCl}$ e tampão bicarbonato de amônio, foi possível separar frações (moléculas) ativas para fitoalexinas em mesocótilos de sorgo (Figuras 26 e 27), com potencial de induzir resistência em plântulas de pepino (Figuras 33 e 36) e em plantas de sorgo (Figuras 40 e 41). Entretanto, somente as frações da CTI com tampão bicarbonato de amônio apresentaram atividade inibitória na germinação de esporos e formação de apressórios pelos fitopatógenos fúngicos (Figuras 31 e 32).

\subsection{Espectrometria de infravermelho}

A análise de infravermelho das preparações de levedura sem autoclavagem ou autoclavada por 4 horas seqüencialmente, confirmou a presença de polissacarídeos, em maior concentração, na preparação 
autoclavada. Portanto, é possível afirmar que o processo de autoclavagem promoveu maior extração dos polissacarídeos presentes na parede celular da levedura, sem afetar a atividade elicitora dos mesmos. O elicitor presente na parede celular de $F$. oxysporum f. sp. albedinis e que promove aumento na atividade de fenilalanina amônia-liase em raízes de plântulas de palma, um possível carboidrato, também mostrou-se termoestável após 45 minutos de autoclavagem (Modafar et al., 2001).

Com relação às proteínas presentes nas preparações foi possível observar que houve alteração na estrutura secundária das mesmas na preparação autoclavada, porém, alteração na estrutura das proteínas não implica em perda da atividade elicitora. Segundo Parker (1991), o elicitor glicoprotéico purificado a partir de $P$. megasperma f. sp. glycinea foi resistente a autoclavagem, indicando que a estrutura quaternária não é necessária para a manutenção da atividade elicitora. A proteína elicitora purificada de $P$. boemeriae e que induz resistência sistêmica em fumo e repolho chinês também se mostrou termoestável (Wang et al., 2003).

Porém, com base nos resultados obtidos não é possível inferir qual composto é responsável pela atividade elicitora da preparação, como proposto por Labanca (2002), que trabalhando com uma fração obtida de levedura por cromatografia de afinidade, confirmou a ausência de proteínas na fração e levantou a hipótese do composto elicitor ter $N$-acetilglucosamina ou glucosamina em sua molécula.

\subsection{Produção de fitoalexinas em mesocótilos de sorgo}

O sorgo sintetiza fitoalexinas pigmentadas da classe dos flavonóides de baixo peso molecular em função do ataque de patógenos (interações compatíveis), não patógenos (interações incompatíveis) ou outros estresses (Aguero et al., 2002; Nicholson et al., 1987; Lo et al., 1996; Hipskind 
et al., 1990). No caso de mesocótilos de sorgo, previamente tratados ou não com abrasivo carborundum e, aspergidos com as preparações de levedura autoclavada por minutos ou horas, uma vez ou seqüencialmente; observou-se o acúmulo de fitoalexinas com coloração laranja a avermelhada (Figura 11) e absorbância máxima aos $480 \mathrm{~nm}$ em extrato metanólico (Figura 12), de acordo com o relatado por Wulff (1997), que trabalhou com mesocótilos imersos nas soluções obtidas de S. cerevisiae.

A aspersão com o ativador comercial ASM sobre mesocótilos de sorgo estiolados não promoveu a síntese das fitoalexinas, ao contrário do que é observado em bioensaios onde os mesocótilos são imersos na suspensão do produto (Bonaldo et al., 2004). Em função do experimento realizado para a obtenção de controles positivos, observou-se que o ferimento promovido pelo abrasivo carborundum favoreceu o acúmulo das fitoalexinas por ASM e provavelmente este acúmulo esta relacionado com a maior superfície de contato ao qual a molécula elicitora é submetida. Observou-se que o acúmulo de fitoalexinas por preparações de levedura também foi maior em mesocótilos previamente tratados com abrasivo carborundum, indicando que o ferimento (injúria) promove um favorecimento da molécula elicitora. Resultados obtidos por Lopez \& Pascholati (1992) indicam que a injúria pode promover o acúmulo de fitoalexinas em mesocótilos de sorgo, enquanto que Wulff (1997) observou que mesocótilos acumularam fitoalexinas como uma resposta à injúria provocada pela excisão na base dos mesmos.

Pelo bioensaio realizado com a adição de antibiótico (Pentabiótico ${ }^{\circledR}$ Veterinário Reforçado) em água destilada esterilizada foi possível observar que o mesmo não altera o acúmulo de fitoalexinas em mesocótilos de sorgo, permitindo então que amostras com alta concentração de carboidratos (como é o caso das amostras das preparações de S. cerevisiae) fossem avaliadas. 


\subsubsection{Efeito de preparações de Saccharomyces cerevisiae na produção de fitoalexinas em mesocótilos de sorgo}

Trabalhos como o de Freitas \& Pascholati (1993) e Roncatto \& Pascholati (1998) demonstraram a capacidade das células de $S$. cerevisiae em promover o acúmulo de fitoalexinas em sorgo. Em acordo com os resultados obtidos por estes autores, todas as preparações de S. cerevisiae, com concentração original e com concentração ajustada de carboidratos, promoveram o acúmulo das fitoalexinas em mesocótilos de sorgo previamente tratados ou não com o abrasivo carborundum.

Foi possível observar o acúmulo de fitoalexinas em mesocótilos de sorgo mesmo em baixas concentrações de carboidratos, uma vez que preparações de S. cerevisiae mesmo diluídas 10.000 vezes estimularam o acúmulo de fitoalexinas neste tecido. Em cotilédones e hipocótilos de soja, concentrações de 15 e $100 \mathrm{ng}$ de $S$. cerevisiae foram suficientes para estimular o acúmulo da fitoalexina gliceolina (Hahn \& Albersheim, 1978). Portanto, em função dos resultados obtidos é provável que a (s) molécula (s) elicitora (s) de fitoalexinas em sorgo, proveniente de $S$. cerevisiae, também seja eficiente em concentrações baixas apresentando alto potencial elicitor de fitoalexinas nesta gramínea. O elicitor purificado a partir de $B$. graminis f. sp. tritici é capaz de induzir respostas de defesa a uma concentração de $0,3 \mu \mathrm{g} / \mathrm{mL}$ de carboidratos (Schweizer et al., 2000). Guzzo \& Moraes (1997) isolaram um elicitor a partir de urediniósporos autoclavados de $H$. vastatrix, que estimulou o acúmulo de gliceolina em cotilédones de soja, mesmo quando concentrações equivalentes a $0,9 \mu \mathrm{g}$ de carboidratos foram aplicadas no cotilédone. Segundo Kim et al. (2001) a maior atividade elicitora de fitoalexinas em ginseng foi observada com a aplicação de $50 \mu \mathrm{g} / \mathrm{mL}$ da preparação elicitora de levedura e a $100 \mu \mathrm{g} / \mathrm{mL}$ da preparação elicitora proveniente de $B$. cinerea. 


\subsubsection{Curva dose resposta na produção de fitoalexinas em mesocótilos de sorgo}

Geralmente, a expressão de mecanismos de defesa esta relacionada à dose resposta do elicitor, sendo que respostas mais intensas são obtidas em função do aumento da dose do elicitor (Tang \& Smith, 2001; Koch et al., 1998; Schaffrath et al., 1995; Yamaoka et al., 1990). Guzzo (1989) observou que a atividade elicitora de gliceolina aumentou quando concentrações crescentes do elicitor purificado de $H$. vastatrix foram aplicadas por cotilédone. Tang \& Smith (2001) constataram que o acúmulo de duas fitoalexinas em alfafa é dependente da concentração do elicitor isolado de $V$. alboatrum. Segundo os autores o acúmulo da fitoalexina medicarpina foi saturado com altas concentrações do elicitor, cerca de $0,10 \mathrm{mg}$ de carboidrato $/ \mathrm{mL}$, enquanto que o acúmulo máximo da fitoalexina "sativan" foi alcançado com 0,01mg de carboidratos $/ \mathrm{mL}$, com decréscimo da produção da mesma na presença de concentrações maiores do elicitor.

A produção de fitoalexinas em mesocótilos de sorgo em função do aumento da concentração de carboidratos presentes na preparação de $S$. cerevisiae, autoclavada por 4 horas seqüencialmente, não apresentou comportamento linear como relatado por Labanca (2002), que trabalhando com elicitor proveniente de $S$. cerevisiae no acúmulo de fitoalexinas do tipo gliceolina observou comportamento linear do acúmulo destas, em função do aumento da dose do elicitor. Entretanto, os dados estão de acordo com Wulff \& Pascholati (1999), que trabalhando com frações parcialmente purificadas obtidas de $S$. cerevisiae, observaram um comportamento não linear em resposta as concentrações crescentes de proteínas no acúmulo de fitoalexinas em mesocótilos de sorgo. Apesar da resposta não ser linear, os autores relataram que o acúmulo de fitoalexinas é maior quanto maior o conteúdo de proteínas (e carboidratos) na preparação elicitora. 


\subsubsection{Produção de fitoalexinas em mesocótilos de sorgo em diferentes tempos de incubação}

O fato de mesocótilos de sorgo tratados com a preparação de levedura iniciarem o acúmulo de fitoalexinas mais rapidamente que o próprio patógeno, C. sublineolum (Figura 20), aproximadamente após 12 horas de incubação, indica que a (s) molécula (s) elicitora (s) presente (s) na preparação é (são) rapidamente reconhecida (s) pelo tecido dos mesocótilos. Aguero et al. (2002) constataram maior acúmulo de fitoalexinas, em sorgo, entre 12 e 32 horas após incubação dos mesocótilos inoculados com Cochliobolus heterostrophus. Kim et al. (2001) observaram um rápido acúmulo de fitoalexina em ginseng, com máxima produção cerca de 12 horas após o tratamento elicitor com preparação de levedura. Enquanto que o tratamento com uma preparação elicitora proveniente de $B$. cinerea, apresentou produção máxima da fitoalexina após 24 horas do tratamento elicitor. Em relação ao controle de doenças, um acúmulo de fitoalexinas mais rápido pode ser um aspecto positivo, uma vez que a planta pode se defender mesmo nas condições em que o patógeno entre em contato com a planta no momento do tratamento com o elicitor. Segundo Snyder \& Nicholson (1990) e Tenkouano et al. (1993), o controle da antracnose do sorgo causada por $C$. sublineolum esta relacionada ao efeito protetor das fitoalexinas e também em função da velocidade de resposta da planta no acúmulo destes compostos.

\subsubsection{Produção de fitoalexinas em sorgo por frações parcialmente purificadas por CTI}

\subsubsection{Produção de fitoalexinas em mesocótilos de sorgo}

$\mathrm{Na}$ produção de fitoalexinas em mesocótilos de sorgo, todas as frações obtidas de S. cerevisiae por CTI com tampão Tris-HCl foram capazes 
de induzir o acúmulo de fitoalexinas em mesocótilos de sorgo, previamente tratados ou não com abrasivo carborundum (Figuras 26). Neste caso, utilizando o tampão Tris- $\mathrm{HCl}$, é possível que moléculas com natureza protéica ou glicosídica apresentem atividade elicitora, ou o elicitor presente nas frações seja capaz de induzir o acúmulo de fitoalexinas nos mesocótilos de sorgo mesmo em baixas concentrações. Com relação às frações provenientes da CTI com tampão bicarbonato de amônio, observa-se que a fração I (fração não ligada) apresentou maior atividade elicitora em mesocótilos sem tratamento prévio com abrasivo carborundum que as demais frações (Figura 27). Este resultado indica a provável importância dos carboidratos da fração, uma vez que mesmo com o ajuste de proteínas realizado, esta fração ainda apresentava alta concentração de carboidratos. Os resultados obtidos no corrente trabalho conflitam com os resultados de Wulff \& Pascholati (1999) que evidenciaram que as frações fortemente ligadas ao trocador aniônico apresentaram maior atividade elicitora em relação às mais fracamente ligadas, enquanto que algumas frações sem afinidade por DEAE-Celulose atuaram como supressoras.

Comparando-se a produção de fitoalexinas em mesocótilos de sorgo em função dos tampões utilizados na eluição da coluna, observa-se que na CTI com tampão Tris- $\mathrm{HCl}$ todas as frações obtidas apresentaram atividade elicitora, enquanto as frações II, IV e V da CTI com tampão bicarbonato de amônio apresentaram baixa atividade elicitora. É provável que neste último caso as moléculas elicitoras estejam concentradas na Fração I (fração não ligada), entretanto não se pode descartar a possibilidade da presença de supressores nas frações II, IV e V, uma vez que nenhum estudo foi realizado na tentativa de excluir esta hipótese. Wulff (1997), trabalhando com o mesmo tipo de elicitores, porém extraídos da levedura através de autoclavagem por 30 minutos, constatou que, além da presença de um forte elicitor do acúmulo de fitoalexinas em mesocótilos de sorgo, estava presente no extrato bruto uma fração capaz de suprimir completamente a síntese das mesmas. 


\subsubsection{Produção de fitoalexinas em folhas de sorgo}

Segundo Snyder \& Nicholson (1990) a indução de proteção é um dos principais mecanismos de controle do patógeno $C$. sublineolum em sorgo, onde a formação de fitoalexinas envolvidas no processo natural de controle do fungo pode ser observada após 24 horas da aplicação de suspensões conidiais do patógeno, devido ao aparecimento de pequenas inclusões contendo fitoalexinas conhecidas como apigeninidina e luteolinidina.

Nos experimentos realizados em casa-de-vegetação, o tratamento com frações parcialmente purificadas obtidas de S. cerevisiae é capaz de promover o acúmulo das fitoalexinas em folhas de sorgo. Entretanto, o maior acúmulo destas fitoalexinas foi observado nas folhas tratadas com o extrato bruto da levedura, após a realização da câmara úmida, que deve ter proporcionado condições favoráveis para a formação das fitoalexinas nas folhas de sorgo. Provavelmente isto tenha ocorrido em função da maior concentração de proteínas e carboidratos da preparação bruta (o que implicaria também na maior aplicação da (s) molécula (s) elicitora (s)) em comparação com as concentrações das frações parcialmente purificadas. Podem estar presentes no extrato bruto uma ou mais moléculas elicitoras (que tenham sido separadas por $\mathrm{CTI}$ ) com maior atividade elicitora quando ambas estejam presentes. Segundo Dixon \& Lamb (1990) pode haver sinergismo entre moléculas elicitoras de natureza química diferente. Sinergismo entre moléculas de mesma natureza química também pode ocorrer, pois segundo Yamaguchi et al. (2002) dois elicitores oligossacarídeos purificados da parede celular de Magnaporte grisea apresentam atividade sinergística na biossíntese de fitoalexinas em culturas de células de arroz.

Além das fitoalexinas é provável que outros mecanismos de defesa como, por exemplo, proteínas relacionadas à patogênese, peroxidases, fenóis, etc., estejam envolvidos na proteção de plantas de sorgo a $C$. sublineolum, uma vez que não foi observada a formação de fitoalexinas nas 
folhas tratadas com ASM, ou nas folhas superiores, embora a melhor proteção das plantas tenha sido proporcionada por este tratamento. O acúmulo de fitoalexinas é observado em relações compatíveis como em relações incompatíveis (Lo et al., 1996; Aguero et al., 2003), sendo que outras respostas de defesa também são necessárias para o estabelecimento da resistência.

A produção de fitoalexinas em folhas superiores de sorgo é mais evidente quando plantas jovens, com 17 dias de idade, recebem o tratamento elicitor provavelmente devido à própria resistência de idade que as plantas apresentam. Assim, em função do tratamento com elicitor associado a resistência que plantas jovens de sorgo apresentam, há o acúmulo das fitoalexinas nas folhas tratadas e nas folhas superiores.

Comparando-se a produção de fitoalexinas em mesocótilos e em folhas de sorgo, observa-se que nem sempre frações que promoveram o acúmulo de fitoalexinas em mesocótilos foram capazes de acumular fitoalexinas nas folhas de sorgo. Provavelmente, em função das condições controladas em que o bioensaio com mesocótilos é realizado, favorecendo o acúmulo das fitoalexinas, bem como em função da idade dos tecidos das plantas, onde tecidos de plantas jovens acumulam fitoalexinas em concentrações maiores que tecidos de plantas adultas (Tenkouano et al., 1993). Também não foi possível correlacionar maior produção de fitoalexinas em mesocótilos de sorgo com maior proteção de plantas contra a doença antracnose.

Portanto, estudos futuros deverão ser realizados com o objetivo de identificar e quantificar as fitoalexinas produzidas em folhas de sorgo, em função do tratamento elicitor com preparações ou moléculas parcialmente purificadas obtidas de $S$. cerevisiae. 
5.4 Efeito de preparações e de frações parcialmente purificadas por CTI, obtidas de Saccharomyces cerevisiae, na germinação de esporos e formação de apressórios por Colletotrichum lagenarium e Colletotrichum sublineolum

A germinação de esporos é um estágio do desenvolvimento essencial no ciclo de todos os fungos filamentosos, e fatores como nutrientes com baixo peso molecular (aminoácidos e açúcares) podem ser necessários para a germinação (D' Enfer, 1997). As preparações de S. cerevisiae com concentração original de carboidratos estimularam em 100\% a germinação de esporos por $C$. lagenarium e $C$. sublineolum. $O$ mesmo comportamento no estímulo da germinação de esporos dos fitopatógenos foi observado quando as preparações de levedura tiveram a concentração de carboidratos ajustada para a concentração da preparação sem autoclavagem (tempo 0). $O$ efeito estimulador na germinação de esporos por fitopatógenos pode ser estar relacionada à presença de substâncias estimuladoras nas preparações de levedura, ou simplesmente por estas apresentarem nutrientes em concentrações favoráveis aos fitopatógenos. O relato de estímulo na germinação de esporos por fitopatógenos já foi observado em outros trabalhos que objetivaram a indução de resistência ou mesmo o controle direto de fitopatógenos. Di Piero \& Pascholati (2002) constataram que filtrados obtidos de culturas das cianobactérias Synechococcus leopoliensis e Nostoc sp. estimularam a germinação de conídios de C. sublineolum. Tonucci (2004), trabalhando com o mesmo patógeno e com frações parcialmente purificadas obtidas do cogumelo shiitake, relatou o efeito estimulador da germinação de esporos por todas as frações testadas. Extratos aquosos de basidiocarpos de isolados de shiitake também estimularam a germinação dos conídios de C. lagenarium (Di Piero, 2003). Segundo Leite \& Nicholson (1993) a presença de nutrientes prontamente disponíveis, em concentrações adequadas, inativa a micosporina-alanina, um autoinibidor de germinação encontrado na mucilagem 
que envolve os conídios de $C$. sublineolum. Portanto, estudos futuros deverão ser realizados para se avaliar a possibilidade da utilização das preparações de S. cerevisiae, no auxílio da germinação de esporos de fitopatógenos com baixa germinação em in vitro, como, por exemplo, G. citricarpa, ou mesmo em bioensaios cujo tratamento controle negativo apresente baixa germinação de esporos, como ocorreu durante o desenvolvimento deste trabalho.

Com relação à curva dose resposta elaborada, foi possível observar que em função do aumento na concentração de carboidratos, ocorre apenas o estímulo da germinação de esporos dos fitopatógenos com ausência da formação de apressórios (Tabelas 3 e 4). Provavelmente, a formação de apressórios em baixas concentrações de carboidratos esta relacionada com a baixa disponibilidade de nutrientes presentes na preparação de $S$. cerevisiae.

Ausência da formação de apressórios em patógenos como $C$. lagenarium e C. sublineolum, pode auxiliar no controle da doença provocada por estes fitopatógenos, pois o apressório é uma estrutura de infecção especializada que se forma a partir de uma hifa ou tubo germinativo, o qual é importante no processo de penetração do fungo através da superfície foliar do hospedeiro (Khan \& Hsiang, 2003). Portanto, sem a penetração do fitopatógeno na célula da planta hospedeira não há o estabelecimento das relações parasitárias estáveis e conseqüentemente tem-se a ausência de doença. Considerando que as preparações, apesar do estímulo da germinação de esporos, promoveram a inibição da formação de apressórios este pode ser um aspecto positivo na indução de resistência e no controle de doenças em plantas.

$\mathrm{Na}$ separação dos componentes da preparação elicitora bruta através de CTI, somente a fração I obtida na CTI com tampão Tris- $\mathrm{HCl}$ não induziu a germinação de esporos por $C$. sublineolum, enquanto que as demais frações induziram a germinação de esporos por ambos os fitopatógenos (Figuras 29 e 30) e houve efeito estimulador da formação de apressórios por $C$. lagenarium. $O$ efeito estimulador da germinação de esporos, esta 
provavelmente relacionado à disponibilidade de nutrientes presentes nas frações e ausência, ou até mesmo perda de moléculas com atividade fungitóxica através da diálise. As frações I e IV provenientes da CTI com tampão bicarbonato de amônio, apresentaram efeito estimulador da germinação de esporos de $C$. lagenarium, sendo que provavelmente nestas frações estejam presentes os compostos (moléculas) estimuladores presentes no extrato bruto e que foram separados das frações com atividade inibitória pela CTI. Observouse inibição da germinação de esporos pelas frações V, VI e VII e as outras frações não apresentaram efeito estatisticamente significativo em relação ao controle negativo. Houve formação de apressórios por $C$. lagenarium na presença da fração I e todas as outras frações testadas inibiram a formação de apressórios, indicando que apesar da fração IV promover estímulo da germinação de esporos, esta apresenta potencial fungitóxico, uma vez que inibe a formação de apressórios pelo fitopatógeno.

Por sua vez as frações I e II estimularam a germinação de esporos e a formação de apressórios de C. sublineolum e as frações III, IV, V, VI e VII apresentaram efeito inibitório na germinação e formação de apressórios (Figura 32). Como já comentado para o caso do patógeno C. lagenarium, é provável que as frações I e II contenham compostos (moléculas) estimuladores da germinação de esporos por $C$. sublineolum, que tenham sido separados das frações com atividade inibitória por CTI com tampão bicarbonato de amônio, ou o estímulo seja devido a presença de nutrientes nas frações. Labanca (2002), trabalhando com frações parcialmente purificadas obtidas de $S$. cerevisiae e incorporadas a meio de cultura, observou aumento acentuado da esporulação, mas sem alteração na velocidade de crescimento micelial de $C$. lagenarium, o que levou a autora a inferir que nenhum dos compostos extraídos da levedura apresentava efeito fungitóxico.

Assim, as frações provenientes da CTI com tampão bicarbonato de amônio podem apresentar efeito inibidor (fungitóxico) ou não para diferentes estruturas dos fitopatógenos. Estudos futuros devem ser realizados para se 
avaliar a natureza das frações com atividade inibitória, onde o emprego de proteinase $\mathrm{k}$ e/ou metaperiodato de sódio, por exemplo, podem colaborar para a elucidação da natureza da (s) molécula (s) com atividade fungitóxica.

\subsection{Proteção de plântulas de pepino a Colletotrichum lagenarium, em câmara de crescimento e em casa-de-vegetação, utilizando as frações obtidas nas CTIs}

As frações elicitoras utilizadas na indução de resistência em plântulas de pepino, em câmara de crescimento ou em casa-de-vegetação, foram uniformizadas tendo como base a menor concentração de proteínas. Frações obtidas na primeira CTI foram ajustadas de acordo com a concentração de proteínas da fração II e concentrações de proteínas das frações obtidas na segunda CTI foram igualadas a concentração de proteínas da fração VII. A escolha de proteínas foi devida à alta concentração de carboidratos presentes na fração I (fração não ligada à coluna), o que levaria a uma alta diluição desta fração, caso se optasse por ajustar as frações baseando-se na concentração de carboidratos presentes.

$\mathrm{Na}$ literatura diversos trabalhos relatam que plantas de pepino são substituídas por plântulas de pepino, sendo que o tratamento elicitor é então aplicado em cotilédones ou hipocótilos (Siegrist et al., 1994; Slovákova et al., 2000; Labanca, 2002). Labanca (2002) relatou que a utilização de plântulas de pepino permite a realização dos bioensaios de modo rápido, com um número razoável de repetições e com gasto mínimo de preparações elicitoras obtidas de S. cerevisiae.

O tratamento de plântulas de pepino com ASM proporcionou o melhor controle da antracnose até com a supressão completa dos sintomas da doença na época da avaliação (Figuras 33, 34 e 35). O potencial do ASM como indutor de resistência já foi demonstrado em diversos patossistemas, como: 
trigo x B. graminis, café $\times$ Cercospora coffeicola, pimentão $\times$ Erwinia carotovora pv. carotovora, pimentão $\times X$. axonopodis pv. vesicatoria (Venâncio et al., 2000); cacau x C. perniciosa e V. dahliae (Resende et al., 2002b).

$\mathrm{Na}$ proteção de plântulas de pepino em câmara de crescimento observou-se que plântulas que receberam a fração $\mathrm{VI}$, dois dias antes do desafio com o patógeno, apresentaram redução na severidade da doença. Porém, quando as plântulas foram inoculadas 3 dias após o tratamento elicitor, a redução na severidade não foi observada. Portanto, o menor intervalo de tempo entre o tratamento elicitor e o desafiador proporcionou controle eficiente da antracnose pelas frações obtidas por CTI com tampão Tris-HCl (Figura 33). Os resultados conflitam com o relatado por Labanca (2002), que observou redução da doença em plântulas de pepino tratadas com elicitor parcialmente purificado de S. cerevisiae e após 3 dias, inoculadas com o desafiador. Di Piero (2003) também relatou que a proteção de plântulas de pepino tratadas com fração parcialmente purificada do cogumelo shiitake ocorria após 3 dias da inoculação com C. lagenarium.

Provavelmente o tempo entre o tratamento com as frações obtidas por CTls e a inoculação do patógeno (período de 3 dias) tenha sido um dos prováveis fatores do insucesso da proteção de plântulas de pepino contra $C$. lagenarium. Segundo Pascholati \& Leite (1995), a proteção induzida é dependente do intervalo de tempo que ocorre entre o tratamento com o indutor e a inoculação do patógeno, dependência que indica que mudanças específicas no metabolismo da planta envolvendo a síntese e/ou acúmulo de substâncias são importantes no fenômeno da resistência induzida.

Em condições ambientais (casa-de-vegetação) as frações provenientes da CTI com tampão Tris- $\mathrm{HCl}$ que promoveram uma redução na severidade da doença, quando o indutor foi aplicado dois dias antes do desafiador em condições controladas (câmara de crescimento), não apresentaram o mesmo comportamento em casa-de-vegetação, proporcionando até o surgimento mais rápido das lesões do que no controle 
negativo (água), ou seja, apresentaram efeito estimulador da doença. $\mathrm{O}$ efeito estimulador pode estar relacionado as condições ambientais em que as plântulas se desenvolveram, devido a presença de supressores de respostas de defesa (Schaffrath et al., 1995; Fauth et al., 1996; Wulff, 1997; Davis et al., 1998) ou em função das grandes quantidades de nutrientes (carboidratos) disponíveis nas frações que podem ter favorecido o desenvolvimento do patógeno na superfície dos cotilédones.

Labanca (2002) relatou que preparados brutos provenientes de $S$. cerevisiae não promoveram indução de resistência em plantas e plântulas de pepino e que possivelmente a precipitação etanólica proporcionou a separação de moléculas interferentes permitindo a obtenção de fração com capacidade de induzir resistência em pepino contra $C$. lagenarium. Como a etapa de precipitação etanólica foi omitida neste trabalho, é possível que moléculas interferentes não tenham sido separadas das moléculas elicitoras, e este pode ser um dos fatores do fracasso da indução de resistência e do favorecimento do surgimento da doença em plântulas de pepino, tratadas com as frações provenientes da CTI com tampão Tris-HCl.

As condições ambientais em que as plantas se desenvolvem antes de serem submetidas a um processo de indução de resistência, no campo, são fundamentais para o êxito da operação (Falkhof et al., 1988). Segundo estes autores condições naturais de luz, temperatura e umidade, como as que existem no campo, favorecem o processo de indução de resistência. Quando os autores trabalharam com feijão, trigo e cevada e os patógenos E. graminis f.sp. hordei, E. graminis f.sp. tritici, Puccinia hordei e U. appendiculatus, usando Bacillus subtilis como indutor; observaram em todos os casos, que a redução na severidade da doença foi consideravelmente maior do que aquela obtida para plantas crescidas em condições controladas antes da aplicação do indutor. Para os autores, a luz e a temperatura mostraram ser fatores limitantes para o êxito do controle induzido, na fase de desenvolvimento da planta anterior ao tratamento, o que indica a intensa relação existente entre 
o estado fisiológico da planta no momento do tratamento indutor e a capacidade da mesma em responder positivamente ao tratamento. Assim, é provável que algum fator ambiental como luz, temperatura ou umidade, tenha promovido algum estresse sobre as plântulas de pepino promovendo o insucesso da proteção das mesmas.

No teste de proteção de plântulas de pepino, em casa-devegetação, com as frações provenientes da CTI com tampão bicarbonato de amônio, a fração III apresentou maior poder de proteção e algumas frações provenientes desta CTI provocaram efeito fitotóxico em cotilédones de pepino. Wulff (1997) relatou a ocorrência de frações supressoras que afetam o desenvolvimento dos folíolos de mesocótilos de sorgo por completo, indicando a possibilidade de efeito fitotóxico. Entretanto, em plantas de sorgo que receberam as mesmas frações não foi observado nenhuma alteração na coloração das folhas, o que indica que a alteração provocada em cotilédones de plântulas de pepino pode estar relacionada à fisiologia da planta que é uma leguminosa. Apesar de ser um aspecto negativo para a proteção de plantas, através da indução de resistência, o fato destas frações promoverem efeito fitotóxico pode ser um aspecto positivo considerando que as moléculas presentes possam ter utilidade no controle de plantas invasoras. $\mathrm{Na}$ literatura diversos trabalhos abordam a alternativa do controle de plantas daninhas por fitopatógenos (Mello et al., 2000). Apesar da levedura S. cerevisiae não ser um fitopatógeno, a separação de frações com atividade fitotóxica pode ser promissor se o mesmo comportamento ocorrer sobre plantas daninhas. Portanto, estudos futuros são necessários para elucidar o efeito destas frações sobre plantas daninhas e o efeito das mesmas em leguminosas e gramíneas.

\subsubsection{Atividade de peroxidases}

O aumento da atividade de peroxidases já foi observado em diversas plantas induzidas, como pepino (Labanca, 2002; Xue et al., 1998; Di 
Piero, 2003), tomate (Baysal et al., 2003), cacau (Resende et al., 2002b), trigo (Stadnik \& Buchenauer, 2000), aspargo (He et al., 2002), feijão (Campos et al., 2004) e melão (Buzi et al., 2004).

No primeiro experimento realizado com plântulas de pepino, somente ASM promoveu o acúmulo de peroxidases, sendo que o aumento foi maior após a inoculação do patógeno $C$. lagenarium (Figura 39). No segundo experimento, após 3 dias do tratamento elicitor com ASM as plântulas já apresentavam alterações na atividade de peroxidases e alterações maiores foram observadas após a inoculação com o patógeno (6 dias após o tratamento elicitor). Demais tratamentos promoveram alterações na atividade de peroxidases principalmente após 3 dias da inoculação com o patógeno. Provavelmente esta alteração na atividade de peroxidases esteja relacionada ao processo de infecção da planta pelo patógeno e não pela atividade elicitora dos tratamentos. Os resultados discordam dos obtidos por Labanca (2002), a qual observou que frações elicitoras provenientes de $S$. cerevisiae promoviam alterações na atividade de peroxidases após 48 horas da inoculação, perdurando até 96 horas após a inoculação do patógeno. Di Piero (2003) relatou que o acúmulo local de peroxidases em pepino induzido por extratos de shiitake foi observado no terceiro e sexto dia após o tratamento elicitor.

A fração III proveniente da CTI com tampão bicarbonato de amônio, promoveu redução na severidade da antracnose, entretanto não houve aumento significativo da atividade de peroxidases nos cotilédones de pepino que foram tratados com esta fração. Neste caso se faz necessário avaliar diferentes intervalos de tempo entre o tratamento elicitor e a inoculação do patógeno para se detectar níveis mais altos de atividade de peroxidases, caso esta enzima esteja envolvida no processo de proteção das plântulas de pepino. A ausência de alteração na atividade de peroxidases pode indicar que outros mecanismos de defesa estejam relacionados à proteção das plântulas que receberam a fração III, como por exemplo, o acúmulo de quitinases e $\beta$-1,3glucanases. Isto reforça a hipótese de ser a resistência induzida um processo 
multicomponente, onde cada componente deve estar no local, quantidade e tempo precisos, pois, alguns indutores de resistência em pepino não elevam significativamente o nível de peroxidases na magnitude da proteção induzida (Schneider \& Ullrich, 1994).

\subsection{Proteção de plantas de sorgo a Colletotrichum sublineolum em casa- de-vegetação utilizando as frações obtidas nas CTIs}

Suspensões de células de S. cerevisiae (linhagem de panificação) e o filtrado das mesmas protegem plantas de sorgo em casa-de-vegetação e campo contra C. sublineolum e E. turcicum (Lopez, 1991; Piccinin, 1995, 2005), com produção de grãos por parte das plantas protegidas próxima da produção exibida pelas plantas tratadas com fungicida. O metabolismo de plantas de sorgo no tocante ao conteúdo de pigmentos, fitoalexinas do tipo deoxiantocianidinas, proteínas totais, fenóis totais, carboidratos totais e enzimas também foi alterado por preparações de S. cerevisiae (Freitas et al., 1993; Lopez, 1991; Roncatto \& Pascholati, 1998). Entretanto, nestes trabalhos não foram feitos estudos quanto à natureza das moléculas que induzem proteção.

No primeiro experimento não foi observado o surgimento de lesões, provavelmente porque as plantas foram inoculadas muito jovens. Segundo Nicholson et al. (1988), folhas de plantas jovens de sorgo raramente exibem sintomas de infecção por $C$. sublineolum em função do acúmulo de fitoalexinas produzidas em resposta à invasão pelo patógeno.

Com relação à proteção local, observada no segundo experimento, apesar de não haver diferença estatisticamente significativa, extrato bruto e as frações III, IV, V e VI, provenientes da CTI com tampão Tris$\mathrm{HCl}$, proporcionaram redução da severidade da doença (Figura 42a), enquanto que a fração I, proveniente da CTI com tampão bicarbonato de amônio, reduziu cerca de $15 \%$ a severidade da doença (Figura 43a). Conforme abordado 
anteriormente, a fração I apresentava maior concentração de carboidratos, sendo possível que a molécula responsável pela proteção das plantas de sorgo apresente natureza glicosídica. Na proteção sistêmica as frações IV, V e VI obtidas na CTI com tampão Tris-HCl (Figura 40b), e as frações I, II, III, IV e VI provenientes da CTI com tampão bicarbonato de amônio e extrato bruto, promoveram uma redução na severidade da doença (Figura 41b). Apesar da resistência induzida não conferir imunidade absoluta contra doenças esta pode, como observado no experimento em questão, reduzir a severidade da doença e o efeito de proteção não pode ser descartado.

Possivelmente, os fatores ambientais (luz, temperatura e umidade, por exemplo), associados ao baixo número de repetições, a natureza da doença e a fisiologia de crescimento das plantas de sorgo podem ter interferido nos resultados fazendo com que diferenças não fossem possíveis de serem detectadas estatisticamente. Estudos futuros devem ser conduzidos com maior número de repetições e em condições mais controladas, objetivando minimizar a interferência dos fatores ambientais sobre o experimento.

Tenkouano et al. (1993), entre outros autores, relatam que o controle da antracnose do sorgo causada por $C$. sublineolum é função do efeito protetor das fitoalexinas e da velocidade de resposta da planta no acúmulo destes compostos. As fitoalexinas são produzidas em inclusões no citoplasma nas células invadidas pelo patógeno e migram para o local de penetração onde aumentam gradualmente, coalescem, tornam-se mais avermelhadas, então se rompem e liberam o conteúdo no citoplasma provocando a morte da célula e restringindo o desenvolvimento do patógeno (Snyder \& Nicholson, 1990). Outro aspecto importante da proteção, devido à produção de fitoalexinas, está relacionado a inespecificidade dessas substâncias quanto aos fitopatógenos controlados. Stangarlin et al. (1994), observaram que a resposta de plantas de sorgo a mancha foliar causada por E. turcicum envolvia o acúmulo de fitoalexinas do tipo apigeninidina, luteolinidina e éster de apigeninidina, sendo semelhantes às produzidas contra $C$. sublineolum. Em ambos os experimentos 
conduzidos no presente trabalho, o extrato bruto da levedura que apresentou maior produção visual de fitoalexinas também promoveu uma das maiores reduções da severidade da doença, entretanto não foi possível correlacionar maior produção de fitoalexinas em mesocótilos de sorgo com uma maior proteção das plantas de sorgo, uma vez que todas as frações obtidas por CTI com tampão Tris- $\mathrm{HCl}$ induziram o acúmulo das fitoalexinas, mas nem todas proporcionaram proteção das plantas de sorgo a antracnose.

De maneira geral, o presente trabalhou evidenciou o potencial de preparações e moléculas parcialmente purificadas, obtidas de $S$. cerevisiae, no acúmulo de fitoalexinas em sorgo e na proteção de plantas, especialmente em sorgo. Estudos futuros com plântulas de pepino devem ser realizados visando uma melhor adequação do bioensaio (com relação ao intervalo de tempo entre indutor-desafiador e concentração do indutor, por exemplo). Como a natureza das moléculas elicitoras obtidas a partir de S. cerevisiae, autoclavada por 4 horas seqüencialmente, não foi determinada, não se exclui a possibilidade de haver mais que uma molécula elicitora da síntese de fitoalexinas em sorgo e da proteção em pepino e sorgo. É possível ainda obter moléculas, com efeito, fungitóxico e outras moléculas capazes de promover fitotoxidez sobre plantas em função do tampão de eluição da coluna e da omissão da etapa de diálise durante o processo de purificação.

Assim, em função das diversas possibilidades de utilização de moléculas obtidas de $S$. cerevisiae demonstradas neste trabalho e também em função da facilidade de aquisição de quantidades elevadas da levedura, por ser um microrganismo de fácil manejo em laboratório (Mendes-Costa \& Moraes, 1999) e devida a possibilidade de transformação de linhagens para maximização na expressão de moléculas elicitoras, os estudos devem continuar no sentido de se caracterizar as moléculas, a fim de proporcionar subsídios tanto para elucidação das questões relativas as interações planta-patógeno em sorgo, bem como vislumbrar a obtenção de uma molécula que possa vir a ser utilizada com fins comerciais no controle de doenças de plantas. 


\section{CONCLUSÕES}

(1) A autoclavagem seqüencial promove maior extração da (s) molécula (s) elicitora (s) presente (s) na parede celular da levedura $S$. cerevisiae, proporcionando maior rendimento na etapa inicial do processo de purificação dos elicitores.

(2) Preparações de S. cerevisiae estimulam a germinação de esporos por $C$. lagenarium e $C$. sublineolum.

(3) A utilização de tampão bicarbonato de amônio facilita a etapa de purificação, proporcionando maior rendimento das frações e proporcionando a obtenção de frações com atividade fungitóxica sobre os fitopatógenos $C$. lagenarium e $C$. sublineolum.

(4) Elicitores presentes na parede celular de S. cerevisiae induzem a síntese de fitoalexinas em folhas e em mesocótilos de sorgo, com e sem tratamento prévio com abrasivo carborundum e apresentam potencial na proteção de plântulas de pepino a $C$. lagenarium e na proteção de plantas de sorgo contra $C$. sublineolum. 


\section{REFERÊNCIAS BIBLIOGRÁFICAS}

AGRIOS, G.N. Plant pathology. 4 ed. San Diego: Academic Press, 1997. 635p.

ABBASI, P.A.; GRAHAM, M.Y.; GRAHAM, T.L. Effects of soybean genotype on the glyceollin elicitation competency of cotyledon tissues to Phytophthora sojae glucan elicitors. Physiological and Molecular Plant Pathology, v.59, p.95-105, 2001.

AGUERO, M.E.; GEVENS, A.; NICHOLSON, R.L. Interaction of Cochliobolus heterostrophus with phytoalexin inclusions in Sorghum bicolor. Physiological and Molecular Plant Pathology, v.61, p.267-271, 2002.

ASSIS, E.M. Componentes da parede celular de leveduras: proteínas e polissacarídeos de interesse das indústrias farmacêuticas e de alimentos. In: "WORKSHOP" - PRODUÇÃO DE BIOMASSA DE LEVEDURA: UTILIZAÇÃO EM ALIMENTAÇÃO HUMANA E ANIMAL, Campinas, 1996. Anais. Campinas: ITAL, 1996. p.41-51.

AYERS, A.R.; EBEL, J.; FINELLI, F.; BERGER, N.; ALBERSHEIM, P.; Quantitative assays of elicitor activity and characterization of the elicitor present in the extracellular medium of cultures of Phytophthora megasperma var. sojae. Plant Physiology, v.57, p.751-759, 1976a. 
AYERS, A.R.; EBEL, J.; VALENT, B.; ALBERSHEIM, P. Fractionation and biological activity of an elicitor isolated from mycelial walls of Phytophthora megasperma var. sojae. Plant Physiology, v.57, p.760-765, 1976b.

BASSE, C.W.; BOLLER, T. Glycopeptide elicitor of stress responses in tomato cells. $N$-linked glycans are essential for activity but act as suppressor of the same activity when released from the glycopeptides. Plant Physiology, v.98, p.1239-1247, 1992.

BAYSAL, Ö.; SOYLU, E.M.; SOYLU, S. Induction of defence-related enzymes and resistance by the plant activator acibenzolar-S-Methyl in tomato seedlings against canker caused by Clavibacter michiganensis ssp. michiganensis. Plant Pathology, v.52, p.747-753, 2003.

BENHAMOU, N.; LAFONTAINE, P. J. Ultrastructural and cytochemical characterization of elicitor-induced structural responses in tomato root tissues infected by Fusarium oxysporum f. sp. radicis-lycopersici. Planta, v.197, p.89-102, 1995.

BENHAMOU, N.; BÉLANGERA R.R.; REY, P.; TIRILLYB, Y. Oligandrin, the elicitin-like protein produced by the mycoparasite Pythium oligandrum, induces systemic resistance to Fusarium crown and root rot in tomato plants Plant Physiology and Biochemistry, v.39, p.681-698, 2001.

BETTIOL, W. (Ed.). Controle biológico de doenças de plantas. Jaguariúna: EMBRAPA-CNPDA, 1991. 388p. 
BONALDO, S.M.; SCHWAN-ESTRADA, K.R.F.; STANGARLIN, J.R.; TESSMANN, D.J.; SCAPIM, C.A. Fungitoxicidade, atividade elicitora de fitoalexinas e proteção de pepino contra Colletotrichum lagenarium pelo extrato aquoso de Eucalyptus citriodora. Fitopatologia Brasileira, v.29, p.128-134, 2004.

BONATTI, P.M.; LORENZINI, G.; FORNASIERO, R.B.; NALI, C.; SGARBI, E. Cytochemical detection of cell wall bound peroxidase in rust infected broad bean leaves. Journal of Phytopathology, v.140, p.319-325, 1994.

BOSTOCK, R.M.; JUC, J.A.; LAINE, R.A. Eicosapentanoic and arachidonic acids from Phytophthora infestans elicit fungitoxic sesquiterpens in the potato. Science, v.212, p.67-69, 1981.

BRADFORD, M.A. A rapid and sensitive method for the quantitation of microgram quanties of protein utilizing the principle of protein-dye binding. Analytical Biochemistry, v.72, p.248-254, 1976.

BUZI, A.; CHILOSI, G.; DE SILLO, D.; MAGRO, P. Induction of resistance in melon to Didymella bryoniae and Sclerotinia sclerotiorum by seed treatments with acibenzolar-S-methyl and methyl jasmonate but not with salicylic acid. Journal of Phytopathology, v.152, p.34-42, 2004.

CABIB, E.; ROBERTS, S; BOWERS, B. Synthesis of the yeast cell wall and its regulation. Annual Review of Biochemistry, v.51, p.763-793, 1982.

CAMPOS, A.D.; FERREIRA, A.G.; HAMPE, M.M.V.; ANTUNES, I.F.; BRANCÃO, N.; SILVEIRA, E.P.; OSÓRIO, V.A.; AUGUSTIN, E. Atividade de peroxidases e polifenoloxidase na resistência do feijão à antracnose. Revista Agropecuária Brasileira, v.39, p.637-643, 2004. 
CHEAH, L.H.; MARSHALL, A.P; POPAY, A.J. Biological control of Fusarium storage rot of squash with yeasts. In: NEW ZEALAND PLANT PROTECTION CONFERENCE, 48., Hastings, 1995. Proceedings. Rotorua: New Zealand Plant Protection Society, 1995a. p.337-339.

CHEAH, L.H.; TRAN, T.B; POPAY, A.J. Postharvest biocontrol of Penicillium rot of lemons with industrial yeasts. In: NEW ZEALAND PLANT PROTECTION CONFERENCE, 48., Hastings, 1995. Proceedings. Rotorua: New Zealand Plant Protection Society, 1995b. p.155-157.

CIA, P.; PASCHOLATI, S.F.; BENATTO, E.A.; CAMILI, E.C. Avaliação de Saccharomyces cerevisiae na proteção pós-colheita de mamão contra antracnose. In: REUNIÃO BRASILEIRA SOBRE INDUÇÃO DE RESISTÊNCIA EM PLANTAS, 2.; SIMPÓSIO DE CONTROLE DE DOENÇAS DE PLANTAS, 4., Lavras, 2004. Resumos. Lavras: UFLA, 2004. p.109.

CIBA, CGA 245704. A plant activator for disease protection. Basel: CIBA Technical Data Sheet, 1995. 9p.

CLÉRIVET, A.; ALAMI, I. Effects of jasmonic acid and of an elicitor from Ceratocystis fimbriata f. sp. platani on the accumulation of phytoalexins in leaves of susceptible and resistant plane trees. Plant Science, v.148, p.105-110, 1999.

COHEN, Y. Induced resistance against fungal diseases by aminobutyric acids. In: LYR, H.; RUSSEL, P.E.; SISLER, H.D. (Ed.). Modern fungicides and antifungal compounds. Andover: Intercept, 1996. p.461-466. 
COOK, R.J.; BAKER, K.F. The nature and practice of biological control of plant pathogens. St. Paul: APS Press, 1983. 539p.

DANIEL, M.; PURKAYASTHA, R.P. Handbook of phytoalexin metabolism and action. New York: Marcel Dekker, 1995. 615p.

DANTAS, S.A.F.; OLIVEIRA, S.M.A.; BEZERRA NETO, E.; COELHO, R.S.B.; SILVA, R.L.X. Indutores de resistência na proteção do mamão contra podridões pós-colheita. Summa Phytopathologica, v.30, p.314-319, 2004.

DAVIS, D.A.; LOW, P.S.; HEINSTEIN, P. Purification of a glycoprotein elicitor of phytoalexin formation from Verticillium dahliae. Physiological and Molecular Plant Pathology, v.52, p.259-273, 1998.

DAVIS, K.R.; DARVILL, A.G.; ALBERSHEIM, P. Several biotic and abiotic elicitors act synergistically in the induction of phytoalexin accumulation in soybean. Plant Molecular Biology. v.6, p.23-32, 1986.

DE WIT, P.J.G.M.; ROSEBOOM, P.H.M. Isolation, partial characterization and specificity of glycoprotein elicitors from culture, mycelium and cell walls of Cladosporium fulvum (syn. Fulvia fulva). Physiological Plant Pathology, v.16, p.391-408, 1980.

D'ENFERT, C. Fungal spore germination: insights from the molecular genetics of Aspergillus nidulans and Neurospora crassa. Fungal Genetics and Biology, v.21, p.163-172, 1997.

DIXON, R.A.; LAMB, C.J. Molecular communication in interactions between plants and microbial pathogens. Annual Review of Plant Physiology and Plant Molecular Biology, v.41, p.339-367, 1990. 
DI PIERO, R.M. Potencial dos cogumelos Lentinula edodes (shiitake) e Agaricus blazei (cogumelo-do-sol) no controle de doenças em plantas de pepino, maracujá e tomate, e a purificação parcial de compostos biologicamente ativos. Piracicaba, 2003. 171p. Tese (Doutorado) - Escola Superior de Agricultura "Luiz de Queiroz", Universidade de São Paulo.

DI PIERO, R.M.; PASCHOLATI, S.F. Efeito das cianobactérias Synechococcus leopoliensis e Nostoc sp. sobre Colletotrichum sublineolum e na interação do patógeno com plantas de sorgo. Fitopatologia Brasileira, v.27, p.163-169, 2002.

DUBOIS, M.; HAMINTON, K.; REBERS, P.; SMITH, C. Colorimetric methods for determination of sugar and related substances. Analytical Chemistry, v.28, p.350-356, 1956.

EBEL, J. Phytoalexin synthesis: the biochemical analysis of the induction process. Annual Review of Phytopathology, v.24, p.235-264, 1986.

FARMER, E.E.; HELGESON, J.P. An extracellular protein from Phytophthora parasitica var. nicotianae is associated with stress metabolite accumulation in tobacco callus. Plant Physiology, v.85, p.733-740, 1987.

FALKHOF, A.G.; DEHNE, H.W. SCHÖNBEC, F. Dependence of the effectiveness of induced resistance on environmental conditions. Journal of Phytopathology, v.123, p.311-321, 1988. 
FAUTH, M.; MERTEN, A.; HAHN, M.G.; JEBLICK, W.; KAUSS, H. Competence for elicitation of $\mathrm{H}_{2} \mathrm{O}_{2}$ in hypocotyls of cucumber is induced by breaching the cuticle and is enhanced by salicylic acid. Plant Physiology, v.110, p.347-354, 1996.

FIALHO, M. B. Efeito in vitro de Saccharomyces cerevisiae sobre Guignardia citricarpa, agente causal da pinta preta dos citros. Piracicaba, 2004. 60p. Dissertação (Mestrado) - Escola Superior de Agricultura "Luiz de Queiroz", Universidade de São Paulo.

FELLBRICH, G., BLUME B.; BRUNNER, F., HIRT, H.; KROJ, T.; LIGTERINK, W.; ROMANSKI, A.; NURNBERGER, T. Phytophthora parasitica elicitor induced reactions in cells of Petroselinum crispum. Plant Cell Physiology, v.41, p.692-701, 2000.

FREITAS, J.C.; ZARAMELLA, G.S.; PASCHOLATI, S.F. Efeito de agentes bióticos e abióticos no acúmulo de um complexo de pigmentos e fitoalexinas em mesocótilos de sorgo. Fitopatologia Brasileira, v.18, p.349, 1993. Suplemento. /Apresentado ao 26. Congresso de Fitopatologia, Gramado, 1993 - Resumo/.

GHINI, R.; KIMATI, H. Resistência de fungos a fungicidas. Jaguariúna: Embrapa Meio Ambiente, 2000. 78p.

GODSHALL, M.A.; LONERGAN, T.A. The effects of sugarcane extracts on the growth of the pathogenic fungus, Colletotrichum falcatum. Physiological an Molecular Plant Pathology, v.30, p. 229-308, 1987. 
GOODMAN, R.N.; KIRÁLY, Z.; WOOD, K.R. The biochemistry and physiology of plant disease. Columbia: University of Missouri Press, 1986. 433p.

GRAND, C.; ROSSIGNOL, M. Changes in the lignification process induced by localized infection of muskmelons with Colletotrichum lagenarium. Plant Science Letters, v.28, p.103-110, 1983.

GUSTINE, D.L.; SHERWOOD, R.T.; MOYER, B.J. Evidence for a new class o peptide elicitor of the hypersensitive reaction from the tomato pathogen Pseudomonas corrugata. Phytopathology, v.85, p.848-853, 1995.

GUZZO, S.D. Elicitação da fitoalexina gliceolina em cotilédones de soja (Glycine max (L.) Merril) por polissacarídeos extracelulares de urediniósporos de Hemileia vastatrix Berr, et Br. Piracicaba, 1989. 152p. Dissertação (Mestrado) - Escola Superior de Agricultura "Luiz de Queiroz", Universidade de São Paulo.

GUZZO, S.D.; MORAES, W.B.C. Purificação e caracterização parcial de um elicitor de fitoalexina em soja, a partir de urediniósporos de Hemileia vastatrix. Fitopatologia Brasileira, v.22, p.396-402, 1997.

HAHLBROCK, K.; SCHEEL, D.; LOGEMANN, E.; NÜRNBERGERT, T.; PARNISKE, M.; REINOLD, S.; SACKS, W.R.; SCHMELZER, E. Oligopeptide elicitor-mediated defense gene activation in cultured parsley cells. Proceedings of the National Academy of Science of the USA, v.92, p.4150-4157, 1995.

HAHN, M.G. Microbial elicitors and their receptors in plants. Annual Review of Phytopathology, v.34, p.387-412, 1996. 
HAHN, M.G.; ALBERSHEIN, P. Isolation and partial characterization of an elicitor from yeast extract. Plant Physiology, v.62, p.107-111, 1978.

HAHN, M.G.; DARVILL, A.G.; ALBERSHEIN, P. The endogenous elicitor, a fragment of a plant cell wall polysaccharide that elicits phytoalexin accumulation in soybean. Plant Physiology, v.68, p.1161-1169, 1981.

HAMMERSCHMIDT, R. Induced disease resistance: how do induced plants stop pathogens? Physiological and Molecular Plant Pathology, v.55, p.77-84, 1999.

HAMMERSCHMIDT, R.; DANN, E.K. Induced resistance to disease. In: RECHCIGL, N.A.; RECHCIGL, J.E. (Ed.). Environmentally safe approaches to crop disease control. Boca Raton: CRC - Lewis Publishers, 1997. p.177-199.

HE, C.Y.; HSIANG, T.; WOLYN, D.J. Induction of systemic disease resistance and pathogen defence responses in Asparagus officinalis inoculated with nonpathogenic strain of Fusarium oxysporum. Plant Pathology, v.51, p.225-230, 2002.

HEITEFUSS, R.; WILLIAMS, P.H. Encyclopedia of plant physiology. New York: Springer-Verlag, 1976. v.4: Physiological plant pathology.

HIJWEGNWN, T.; VERHAAR, M.A.; ZADOKS, J.C. Resistance to Sphaerotheca pannosa in roses induced by 2,6-dichloroisonicotinic acid. Plant Pathology, v.45, p.632-635, 1996. 
HIPSKIND, J.; HANAU, R.; LEITE, B.; NICHOLSON, R.L. Phytoalexin accumulation in sorghum: identification of an apigeninidin acyl ester. Physiological and Molecular Plant Pathology, v.36, p.381-396, 1990.

HIPSKIND, J.; WOOD, K.V.; LEITE, B.; CHAND, T.; LEMBI, C.A.; NICHOLSON, R.L. A fungitoxic phenolic compounds in Hydrilla verticillata. Biological Control, v.2, p.51-58, 1992.

HOAGLAND, R.E. Biochemical responses of plants to pathogens. In: HOAGLAND, R.E. (Ed.). Microbes and microbial products as herbicides. Washington: American Chemical Society, 1990. p.87-113.

ISAAC, S. Fungal and plant interactions. Fungal-plant interactions. Cambridge: Chapman and Hall, 1992. 418p.

KAMOUN, S.; YOUNG, M.; GLASCOCK, C.B.; TYLER, B.M. Extracellular protein elicitors from Phytophthora: host-specificity and induction of resistance to bacterial and fungal phytopathogens. Molecular Plant Microbe Interactions, v.6, p.15-25, 1993.

KEEN, N.T. Specific elicitors of plant phytoalexin production: determinants of race specificity in pathogens? Science, v.187, p.74-75, 1975.

KELLER, H.; BLEIN, J-P.; BONNET, P.; RICCI, P. Physiological and molecular characteristics of elicitin-induced systemic acquired resistance in tobacco. Plant Physiology, v.110, p.365-376, 1996.

KHAN, A.; HSIANG, T. The infection process of Colletotrichum graminicola and relative aggressiveness on four turfgrass species. Canadian Journal of Microbiology, v.49, p.433-442, 2003. 
KIM, C.Y.; IM, H.W.; KIM, H.K.; HUH, H. Accumulation of 2,5-dimethoxy-1,4benzoquinone in suspension cultures of Panax ginseng by a fungal elicitor preparation and a yeast elicitor preparation. Applied Microbiology Biotechnology, v.56, p.239-242, 2001.

KOCH, W.; WAGNER, C.; SEITZ, U. Elicitor-induced cell death and phytoalexin synthesis in Daucus carota L. Planta, v.206, p.523-532, 1998.

KOSUGUE, T. The role of phenolics in host response to infection. Annual Review of Phytopathology, v.7, p.195-222, 1969.

KUC, J. Plant immunization and its applicability for disease control. In: CHET, I. (Ed.). Innovative approaches to plant disease control. New York: John Wiley, 1987. cap.12, p.255-274.

LABANCA, E.R.G. Purificação parcial de elicitores presentes em Saccharomyces cerevisiae: atividade como indutores de resistência em pepino (Cucumis sativus) contra Colletotrichum lagenarium e da síntese de gliceolinas em soja (Glycine max). Piracicaba, 2002. 118p. Dissertação (Mestrado) - Escola Superior de Agricultura "Luiz de Queiroz", Universidade de São Paulo.

LEITE, B.; NICHOLSON, R.L. Mycosporine-alanine: a self-inhibitor of germination from the conidial mucilage of Colletotrichum graminicola. Experimental Mycology, v.16, p.76-86, 1992.

LO, L.C.; WEIERGANG, I.; BONHAM, C.; HIPSKIND, J.; WOOD, K.; NICHOLSON, R.L. Phytoalexin accumulation ins sorghum: identification of a methyl ether of luteolinidin. Physiological and Molecular Plant Pathology, v.49, p.21-31, 1996. 
LO, S.C.; DE VERDIER, K.; NICHOLSON, R. L. Accumulation of 3deoxyanthocyanidin phytoalexins and resistance to Colletotrichum sublineolum in sorghum. Physiological and Molecular Plant Pathology, v.55, n.5, p.263-273, 1999.

LOJKOWSKA, E.; HOLOBOWSKA, M. The role of polyphenol oxidase and peroxidase in potato tuber resistance to soft rot caused by Erwinia carotovora. Journal of Phytopathology, v. 136, p. 319-328, 1992.

LOPEZ, A.M.Q.; Controle alternativo de antracnose causada por Colletotrichum graminicola (Ces) Wills em sorgo (Sorghum bicolor L. (Moench)). Rio Claro, 1991. 203p. Dissertação (Mestrado) - Instituto de Biociências do Campus de Rio Claro, Universidade Estadual Paulista "Júlio de Mesquita Filho".

LOPEZ, A.M.Q.; PASCHOLATI, S.F. Accumulation of a complex of pigments in sorghum mesocotyls in response to wounding. Journal of Phytopathology, v.135, p.63-70, 1992.

LYON, G.D.; REGLINSKI, T.; NEWTON, A.C. Novel disease compounds: the potential to 'immunize' plants against infection. Plant Pathology, v.44, p.407-427, 1995a.

LYON, G.D.; REGLINSKI, T.; FORREST, R.S.; NEWTON, A.C. The use of resistance elicitors to control plant diseases. Aspects of Applied Biology, v.42, p.227-234, 1995b.

LÜCK, H. Peroxidase. In: BERGMEYER, H.U. (Ed.). Methods of enzymatic analysis. 2. ed., New York, Academic Press, 1965, p. 895-897. 
MANDER, M.; FUSSI, R.N. Role of peroxidase in lignification of tobacco cell: regulation by phenolic compounds. Plant Physiology, v. 20, p.1132-1134, 1982.

MARGIS-PINHEIRO, M.; SANDRONI, M.; LUMMERZHEIM, M.; OLIVEIRA, D.E. A defesa das plantas contra as doenças. Ciência Hoje, v.25, p.25-32, 1999.

MARTINS, E.M.F. Controle da ferrugem do cafeeiro (Hemileia vastatrix) através da indução de resistência. In: BETTIOL, W. (Ed.). Controle biológico de doenças de plantas. Brasília: EMBRAPA, 1991. cap. 24, p. 345-363.

MARTINS, E.M.F.; MORAES, W.B.C. Development of Hemileia vastatrix in coffee plants with genetic or induce resistance. Journal of Phytopathology, v. 144, p. 519-526, 1996.

MARTINS, E.M.F.; DE MARIA, A.C.; GRÜNEWALDT-STÖCKER, G.; MORAES, W.B.C. Changes in the resistance of detached coffee leaves by yeast extract filtrate and heat treatment. Fitopatologia Brasileira, v.11, p. 899909, 1986.

MELLO, S.C.M.; ÁVILA, Z.R.; FONTES, E.M.G.; RIBEIRO, Z.M.A.; PAIS, J.S.O. Processo de produção do fungo Alternaria cassiae para biocontrole de fedegoso (Senna obtusifolia). Brasília: EMBRAPA - Recursos Genéticos e Biotecnologia, 2000. 27p. (Boletim de pesquisa, 18).

MENDES-COSTA, M.C.; MORAES, W.B.C. Comparação entre os teores de carboidratos totais solúveis presentes em distintas frações de levedura Saccharomyces cerevisiae Meyen. Revista Brasileira de Biologia, v.59, p.1-9, 1999. 
MISAGHI, I.J. Physiology and biochemistry of plant-pathogen interactions. New York: Plenun Press, 1982. 287p.

MODAFAR, C. E.; TANTAOUI, A.; BOUSTANI, E. Differential induction of phenylalanine ammonia-lyase activity in date palm roots in response to inoculation with Fusarium oxysporum f. sp. albedinis and to elicitation with fungal wall elicitor. Journal of Plant Physiology, v. 158, p.715-722, 2001.

MORAES, W.B.C. Controle alternativo de fitopatógenos. Pesquisa Agropecuária Brasileira, v.27, p.175-190, 1992.

NAKAJIMA, T.; BALLOU, C.E. Characterization of the carbohydrate fragments obtained from Saccharomyces cerevisiae mannan by alkaline degradation. Journal of Biological Chemistry, v.249, p.271-278, 1988.

NICHOLSON, R.L.; HAMMERSCCHMIDT, R. Phenolic compounds and their role in disease resistance. Annual Review of Phytopathology, v.30, p.369389, 1992.

NICHOLSON, R.L.; JAMIL, F.F.; SNYDER, B.A.; LUE, W.L.; HISPKIND, J. Phytoalexin synthesis in the juvenile sorghum leaf. Physiological and Molecular Plant Pathology, v.33, p.271-278, 1988.

NICHOLSON, R.L.; KOLLIPARA, S.S.; VINCENT, J.R.; LYONS, P.C.; CADENA-GOMEZ, G. Phytoalexin synthesis by the sorghum mesocotyl in response to infection by pathogenic and nonpathogenic fungi. Proceedings of the National Academy Science of the USA, v.84, p.5520-5524, 1987. 
NÜRBERGER, T.; NENNSTIEL, D.; JABS, T.; RENELT, A.; SACKS, W.R.; HAHLBROCK, K.; SCHEEL, D. High affinity binding of a fungal oligopeptide elicitor to parsley plasma membranes triggers multiple defense responses. Cell, v.78, p.449-460, 1994.

OKINAKA, Y.; MINORI, K.; TAKEO, K.; KITAMURA, S.; TAKEUCHI, Y.; YAMAOKA, N.; YOSHIKAWA, M. A structural model for the mechanisms of elicitor release from fungal cell walls by plant $\beta-1,3$ endoglucanase. Plant Physiology, v.109, p.839-845, 1995.

OKUBO, Y.; ICHIKAWA, T.; SUZUKI, S. Relationship between phosphate content and immunochemical properties of subfractions of baker's yeast mannan. Journal of Bacteriology, v.136, p.63-68, 1978.

PARKER, J.E.; SCHULTE, W.; HALBROCK, K.; SCHEEL, D. An extracellular glycoprotein from Phytophthora megasperma f.sp. glycinea elicits phytoalexin synthesis in cultured parsley cells and protoplasts. Molecular Plant Microbe Interacions, v.4, p.19-27, 1991.

PASCHOLATI, S.F. Potencial de Saccharomyces cerevisiae e outros agentes bióticos na proteção de plantas contra patógenos. Piracicaba, 1998. 123p. Tese (Livre Docência) - Escola Superior de Agricultura "Luiz de Queiroz", Universidade de São Paulo.

PASCHOLATI, S.F.; LEITE, B. Hospedeiro: mecanismos de resistência. In: BERGAMIN FILHO, A.; KIMATI, H.; AMORIM, L. (Ed.). Manual de fitopatologia: Princípios e conceitos. 3. ed. São Paulo: Agronômica Ceres, 1995. v.1. cap.22, p.417-454. 
PASCHOLATI, S.F.; LEITE, B. Mecanismos bioquímicos de resistência a doenças. In: LUZ, W.C. (Ed.). Revisão anual de patologia de plantas. Passo Fundo: Revisão Anual de Patologia de Plantas, 1994. v.2, p.1-52.

PASCHOLATI, S.F.; CIA, P.; BENATTO, E.A.; CAMILI, E.C. O fenômeno da indução de resistência e o controle de doenças em pós-colheita. In: REUNIÃO BRASILEIRA SOBRE INDUÇÃO DE RESISTÊNCIA EM PLANTAS, 2.; SIMPÓSIO DE CONTROLE DE DOENÇAS DE PLANTAS, 4., Lavras, 2004. Resumos. Lavras: UFLA, 2004. p.2-6.

PICCININ, E. Uso de Saccharomyces cerevisiae na proteção de plantas de sorgo (Sorghum bicolor), maracujá azedo (Passiflora edulis) e eucalipto (Eucalyptus spp.) contra fitopatógenos fúngicos e bacterianos. Piracicaba, 1995. 107p. Dissertação (Mestrado) - Escola Superior de Agricultura "Luiz de Queiroz", Universidade de São Paulo.

PICCININ, E.; DI PIERO, R.M.; PASCHOLATI, S.F. Efeito de Saccharomyces cerevisiae na produtividade de sorgo e na severidade de doenças foliares em campo. Fitopatologia Brasileira, v.30, p.10-14, 2005 (no prelo).

PURKAYASTHA, R.P. Progress in phytoalexin research during the past 50 years. In: DANIEL, M.; PURKAYASTHA, R.P. (Ed.). Handbook of Phytoalexin Metabolism and Action. New York: Marcel Dekker, 1995, p.139.

REGENTE, M.C.; OLIVA, C.R.; FFELDMAN, M.L.; CASTAGNARO, A.P.; CANAL, L. A sunflower leaf antifungal peptide active against Sclerotinia sclerotiorum. Physiologia Plantarum, v.100, p.178-182, 1997. 
REGLINSKI, T.; LYON, G.D.; NEWTON, A.C. Induction of resistance mechanism in barley by yeast-derived elicitors. Annals of Applied Biology, v.124, p.509-517, 1994a.

REGLINSKI, T.; NEWTON, A.C.; LYON, G.D. Assessment of the ability of yeastderived resistance elicitors to control barley powdery mildew in the field. Journal of Plant Diseases and Protection, v.101, p. 1-10, 1994b.

RESENDE, M.L.V. de.; NOJOSA, G.B.A.; SANTOS, F.S.; COSTA, J.C.B.; FERREIRA, J.B.; ARAÚJO, D.V.; MUNIZ, M.F.S.; DEUNER, C.C.; MIRANDA, J.C. Ativadores de resistência disponíveis comercialmente. In: REUNIÃO BRASILEIRA SOBRE INDUÇÃO DE RESISTÊNCIA EM PLANTAS, 2.; SIMPÓSIO DE CONTROLE DE DOENÇAS DE PLANTAS, 4., Lavras, 2004. Resumos. Lavras: UFLA, 2004. p.82-97.

RESENDE, M.L.V. de.; BARRRETTI, P.B.; DIAS, W.P. Percepção, transdução e tradução de sinais para respostas de defesa contra patógenos em planta. In: SIMPÓSIO DE BIOLOGIA MOLECULAR DA RESISTÊNCIA DE PLANTAS A PATÓGENOS: APLICAÇÕES NO MANEJO INTEGRADO DE FITODOENÇAS, Lavras, 2002. Resumos. Lavras: UFLA, 2002a. p.9.

RESENDE, M.L.V. de; NOJOSA, G.B.A.; CAVALCANTI, L.S.; AGUILAR, M.A.G.; SILVA, L.H.C.P.; PEREZ, J.O.; ANDRADE, G.C.G.; CARVALHO, G.A.; CASTRO, R.M. Induction of resistance in cocoa against Crinipellis perniciosa and Verticillium dahliae by acibenzolar-S-methyl (ASM). Plant Pathology, v.51, p.621-628, 2002b. 
REUVENI, R.; SHIMONI, M.; CRUTE, I.R.; An association between high peroxidase activity in lettuce (Lactuca sativa) and field resistance to downy mildew (Bremia lactucae). Journal of Phytopathology, v.132, p.312-318, 1991.

$\mathrm{RICCl}, \mathrm{P}$. Induction of the hypersensitive response and systemic acquired resistance by fungal proteins: the case of elicitins. In: STACEY, G.; KEEN, N. Plant-microbe interactions. New York: Chapman \& Hall, 1997. cap.3, p.5375.

RICCI, P.; BONNET, P.; HUET, J.C.; SALLANTIN, M.; BEAUVAIS-CANTE, F.; BRUNETEU, M.; BILLARD, V.; MICHEL, G.; PERNOLLET, J.C. Structure and activity of proteins from pathogenic fungi Phytophthora eliciting necrosis and acquired resistance in tobacco. European Journal of Biochemistry, v.183, p.555-563, 1989.

ROBY, D.; TOPPAN, A.; ESQUERRÉ-TUGAYÉ, M.T. Elicitors of fungal and of plant origin trigger the synthesis of ethylene and cell wall hydroxyprolin-rich glycoprotein in plants. Plant Physiology, v.77, p.700-704, 1985.

RONCATTO, M.C.; PACHOLATI, S.F. Mesocótilos estiolados de sorgo: bioensaio para a caracterização de frações de Saccharomyces cerevisiae envolvidas na proteção de plantas de sorgo contra fungos. In: REUNIÃO ANUAL DO INSTITUTO BIOLÓGICO, 6., São Paulo, 1993. Resumos. São Paulo: Instituto Biológico, 1993. p.31.

RONCATTO, M.C.; PACHOLATI, S.F. Alterações na atividade e no perfil eletroforético da peroxidase em folhas de milho (Zea mays) e sorgo (Sorghum bicolor) tratadas com levedura (Saccharomyces cerevisiae). Scientia Agricola, v. 55, n.3, p.395-402, 1998. 
ROMEIRO, R.S. ISR-SAR: pesquisa com procariotas para indução de resistência em plantas a patógenos, na Universidade Federal de Viçosa. In: SIMPÓSIO DE BIOLOGIA MOLECULAR DA RESISTÊNCIA DE PLANTAS A PATÓGENOS: APLICAÇÕES NO MANEJO INTEGRADO DE FITODOENÇAS, 1., Lavras, 2002. Resumos. Lavras: UFLA, 2002. p.87.

ROVERATTI, D.S. Proteção de plantas de café (Coffea arabica L.) contra Hemileia vastatrix Berk. et Br. por Saccharomyces cerevisiae. Piracicaba, 1989. 94p. Dissertação (Mestrado) - Escola Superior de Agricultura "Luiz de Queiroz", Universidade de São Paulo.

SCHNEIDER, M.; SCHWEIZER, P.; MEUWLY, P.; MÉTRAUX, J.P. Systemic acquired resistance in plants. International Review of Cytology, v.168, p.303-340, 1996.

SCHNEIDER, S.; ULLRICH, W.R. Differential induction of resistance and enhanced enzyme activities in cucumber and tobacco caused by treatment with various abiotic and biotic inducers. Physiological and molecular Plant Pathology, v.45, p.291-304, 1994.

SCHWEIZER, P.; KMECL, A.; CARPITA, N.; DUDLER, R. A soluble carbohydrate elicitor from Blumeria graminis f. sp. tritici is recognized by a broad range of cereals. Physiological and Molecular Plant Pathology, v.56, p.157-167, 2000.

SCHAFFRATH, U.; SCHEINPFLUG, H.; REISENER, H.J. An elicitor from Pyricularia oryzae induces resistance responses in rice: isolation, characterization and physiological properties. Physiological and Molecular Plant Pathology, v.46, p.293-307, 1995. 
SHARP, J.K.; NCNEIL, M.; ALBERSHEIM, P. The primary structures of one elicitor -active and seven elicitor inactive hexa ( $\beta$-D-glycopyranosyl)-Dglucitols isolated from the mycelial walls of Phytophthora megasperma f.sp, glycinea. Journal of Biological Chemistry, v.259, p.11321-11336, 1984.

SHIBATA, N.; MIZUGAMI, K.; TAKANO, K.; SUZUKI, S. Isolation of mannanprotein complexes from viable cells of Saccharomyces cerevisiae X2180-1A wild type and X2180-1A5 mutant strains by the action of zymolyase-60 000 . Journal of Bacteriology, v.156, p.552-558. 1983.

SHIRAISHI, T.; YAMADA, T.; ICHINOSE, Y.; KIBA, A.; TOYODA, K.; KATO, T.; MURAKAMI, Y.; SEKI, H. Suppressor as a factor determining plant-pathogen specificity. In: STACEY, G.; KEEN, N.T. (Ed.). Plant-microbe interactions. New York: Chapman \& Hall, 1997. v.4, cap. 5, p.121-161.

SIEGRIST, J.; JEBLICK, W.; KAUSS, H. Defense response in infected and elicited cucumber (Cucumis sativus L.) hypocotyls segments exhibiting acquired resistance. Plant Physiology, v.105, p.1365-1374, 1994.

SILVA, S.R.; PASCHOLATI, S.F. Saccharomyces cerevisiae protects maize plants, under greenhouse conditions, against Colletotrichum graminicola. Journal of Plant Disease and Protection, v.99, p.159-167, 1992.

SINDAG. http://www.sindag.com.br/new/upload/inforsetor/consumo_mundial.xls (17 nov. 2004).

SLOVÁKOVA, L.; LISKOVA, D.; CAPEK, P.; KUBACKOVÁ, M.; KÁKONIOVÁ, D.; KARACSONYI, S. Defense responses against TNV infection induced by galactoglucomannan-derived oligosaccharides in cucumber cells. European Journal of Plant Pathology, v.106, p.543-553, 2000. 
SMITH, D.A. Toxicity of phytoalexins. In: BAILEY, J.A.; MANSFIELD, J.W. (Ed.). Phytoalexins. Glasgow: Blackie, 1982. p.218-252.

SMITH, C.J. Accumulation of phytoalexins: defense mechanisms and stimulus response system. The New Phytologist, v. 132, p.1-45, 1996.

SNYDER, B.; NICHOLSON, R.L. Synthesis of phytoalexins in sorghum as a site response to fungal ingress. Science, v.248, p.1637-1639, 1990.

SNYDER, B.A.; LEITE, B.; HIPSKIND, J.; BUTLER, L.G.; NICHOLSON, R.L. Accumulation of sorghum phytoalexins induced by Colletotrichum graminicola at the infection site. Physiological and Molecular Plant Pathology, v.39, p.463-470, 1991.

STADNIK, M.J.; BUCHENAUER, H. Inhibition of phenylalanine ammonia-lyase suppresses the resistance induced by benzothiadiazole in wheat to Blumeria graminis f.sp. tritici. Physiological and Molecular Plant Pathology, v.57, p.25-34, 2000.

STANGARLIN, J.R.; SCHWAN-ESTRADA, K.R.F.; CRUZ, M.E.S.; NOZAKI, M.H. Plantas medicinais e controle alternativo de fitopatógenos. Biotecnologia Ciência \& Desenvolvimento, v.11, p.16-21, 1999.

STANGARLIN, J.R. Caracterização de sítios de infecção de Exserohilum turcicum (Pass.) Leonard \& Suggs em diferentes genótipos de milho (Zea mays L.), com base nos mecanismos de defesa vegetal. Piracicaba, 1995. 93p. Dissertação (Mestrado) - Escola Superior de Agricultura "Luiz de Queiroz", Universidade de São Paulo. 
STANGARLIN, J.R.; PASCHOLATI, S.F. Proteção de plântulas de milho pipoca contra Exserohilum turcicum pelo uso de Saccharomyces cerevisiae. Summa Phytopathologica, v.20, p.16-21, 1994.

STICHER, L.; MAUCH-MANI, B.; MÉTRAUX, J.P. Systemic acquired resistance. Annual Review of Phytopathology, v.35, p. 235-270, 1997.

TANG, M.; SMITH, C.J. Elicitor induced defence responses in Medicago sativa. New Phytologist, v.149, p.401-418, 2001.

TAKENAKA, S.; NISHIO, Z.; NAKAMURA, Y. Induction of defense reactions in sugar beet and wheat by treatment with cell wall protein fractions from the micoparasite Pythium oligandrum. Phytopathology, v.93, p.1228-1232, 2003.

TENKOUANO, A.; MILLER, F.R.; HART, G.E.; FREDERIKSEN; NICHOLSON, R.L. Phytoalexin assay in juvenile sorghum: an aid to breeding for anthracnose resistance. Crop Science, v. 33, p.243-248, 1993.

TONUCCI, N.M. Efeito de extratos aquosos do basidiocarpo e micélio de Lentinula edodes (Shiitake) sobre Colletotrichum sublineolum, Alternaria solani, Xanthomonas axonopodis pv. passiflorae e Tobacco mosaic vírus (TMV). Piracicaba, 2004. 88p. Dissertação (Mestrado) - Escola Superior de Agricultura “Luiz de Queiroz", Universidade de São Paulo.

VENÂNCIO, W.S.; ZAGONEL, J.; FURTADO, E.L.; SOUZA, N.L.; PERES, N.A.R. Novos fungicidas. II - Famaxadone e indutores de resistência. Revisão Anual de Patologia de Plantas, v.8, p.59-92, 2000. 
WANG, HU, D.W.; ZHANG,Z.G.; MA,Z.C.; ZHENG, X.B.;LI, D.B. Purification and immunocytolocalization of a novel Phytophthora boehmeriae protein inducing the hypersensitive response and systemic acquired resistance in tobacco and Chinese cabbage Physiological and Molecular Plant Pathology, v.63, p.223-23, 2003

WHARTON, P. S.; NICHOLSON, R. L. Temporal synthesis and radiolabelling of the sorghum 3-deoxyanthocyanidin phytoalexins and the anthocyanin, cyanidin 3-dimalonil glucoside. New Phytologist, v.145, p.457-469, 2000.

WULFF, N.A. Caracterização parcial de elicitores de fitoalexinas em sorgo (Sorghum bicolor) obtidos a partir de Saccharomyces cerevisiae. Piracicaba, 1997. 61p. Dissertação (Mestrado) - Escola Superior de Agricultura "Luiz de Queiroz", Universidade de São Paulo.

WULFF, N.A.; PASCHOLATI, S.F. Preparações de Saccharomyces cerevisiae elicitoras de fitoalexinas em mesocótilos de sorgo. Scientia Agricola, v.55, p.138-143, 1998.

WULFF, N. A.; PASCHOLATI, S. F. Partial characterization of sorghum phytoalexin elicitors isolated from Saccharomyces cerevisiae. Fitopatologia Brasileira, v.24, p. 428-435, 1999.

XUE, L.; CHAREST, P.M.; JABAJI-HARE, S.H. Systemic induction of peroxidases, 1,3- $\beta$-glucanase, chitinase, and resistance in bean plants by binucleate Rhizoctonia species. Biological control, v.88, p.359-368, 1998.

YAMAOKA, N.; LYONS, P.C.; HIPSKIND, J.; NICHOLSON, R.L. Elicitor of sorghum phytoalexin synthesis from Colletotrichum graminicola. Physiological and Molecular Plant Pathology, v.37, p.255-270, 1990. 
YAMAGUCHI, T.; MAEHARA, Y.; KODAMA, O.; OKADA, M.; MATSUMURA, M.; SHIBUYA, $N$. Two purified oligosaccharide elicitors, $N$ acetylchitohepatose and tetraglucosyl glucitol, derived from Magnaporthe grisea cell walls, synergistically activate biosynthesis of phytoalexin in suspension-cultured rice cells. Journal Plant Physiology, v. 159, p.1147-1149, 2002.

YE, X.S.; PAN, S.Q.; KUC, J. Activity, isozyme pattern, and cellular localization of peroxidase as related to systemic resistance of tobacco to blue mold (Peronospora tabacina) and to tobacco mosaic virus. Phytopathology, v.80, p.1295-1299, 1990.

ZADOKS, J.C. The costs of change in plant protection. Journal of Plant Protection, v.9, p.151-159, 1992. 
APÊNDICES 
APÊNDICE 1 - Soluções usadas para a regeneração da resina de cromatografia DEAE-Celulose: seqüência de uso, concentrações e volumes

\begin{tabular}{cccc}
\hline & Reagente & Concentração (M) & Volume (mL) \\
\hline $1^{\circ}$ & Água & - & 100 \\
$2^{\circ}$ & $\mathrm{NaOH}$ & 0,10 & 160 \\
$3^{\circ}$ & Água & - & 100 \\
$4^{\circ}$ & $\mathrm{HCl}$ & 0,10 & 160 \\
$5^{\circ}$ & Água & - & 100 \\
$6^{\circ}$ & Tris- $\mathrm{HCl}(\mathrm{pH} \mathrm{8,0)}$ & 0,05 & 100 \\
$7^{\circ}$ & Tris- $\mathrm{HCl}(\mathrm{pH} \mathrm{8,0)}$ & 0,01 & 200 \\
\hline
\end{tabular}


APÊNDICE 2 - (a). Curva padrão para a dosagem de proteínas através do método de Bradford; (b). Curva padrão para a dosagem de carboidratos através do método fenol sulfúrico

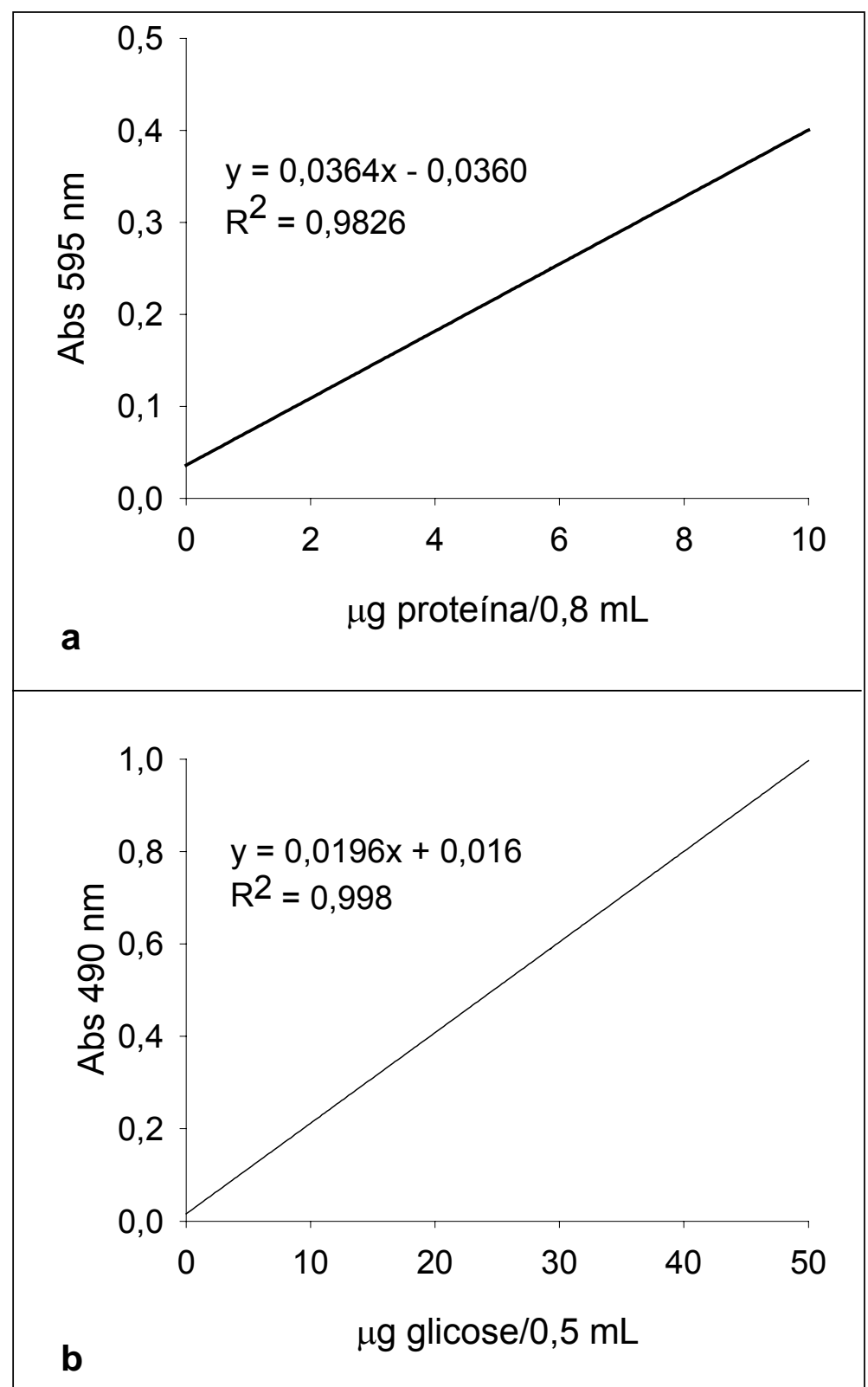


APÊNDICE 3 - Frações representadas por diferentes picos ilustrados nas Figura 23a e 23b

\section{Figura 23a}

Fração I - frações 1 a 6

Fração II - frações 7 a 23

Fração III - frações 25 a 38

Fração IV - frações 39 a 48

Fração V - frações 49 a 67

Fração VI - frações 68 a 82

Figura 23b

Fração I - frações 9 a 28

Fração II - frações 29 a 43

Fração III - frações 44 a 51

Fração IV - frações 52 a 58

Fração $V$ - frações 59 a 70

Fração VI - frações 71 a 87

Fração VII - frações 88 a 94 